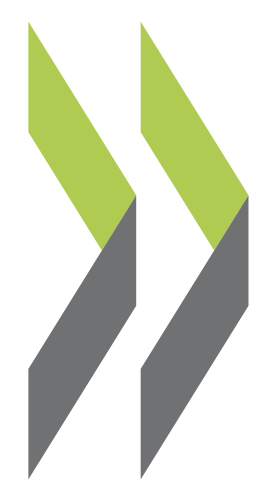

OECD Working Papers on International Investment 2014/01

\title{
Investment Treaty Law, Sustainable Development and Responsible Business Conduct: A Fact Finding \\ Survey
}

Kathryn Gordon, Joachim Pohl, Marie Bouchard 


\section{OECD WORKING PAPERS ON INTERNATIONAL INVESTMENT}

The international investment working paper series - including policies and trends and the broader implications of multinational enterprise - is designed to make available to a wide readership selected studies by the OECD Investment Committee, OECD Investment Division staff, or by outside consultants working on OECD Investment Committee projects.

The papers are generally available only in their original language English or French with a summary in the other if available.

Comment on the series is welcome, and should be sent to investment@oecd.org or the Investment Division, OECD, 2, rue André Pascal, 75775 PARIS CEDEX 16, France.

OECD WORKING PAPERS ON INTERNATIONAL INVESTMENT

are published on www.oecd.org/daf/inv/investment-policy/working-papers.htm.

OECD Working Papers should not be reported as representing the official views of the OECD or of its member countries. The opinions expressed and arguments employed are those of the authors.

Working Papers describe preliminary results or research in progress by the author(s) and are published to stimulate discussion on a broad range of issues on which the OECD works. Comments on Working Papers are welcomed, and may be sent to investment @ oecd.org or the Investment Division, Directorate for Financial and Enterprise Affairs, OECD, 2 rue André-Pascal, 75775 Paris Cedex 16, France.

This document and any map included herein are without prejudice to the status of or sovereignty over any territory, to the delimitation of international frontiers and boundaries and to the name of any territory, city or area.

The statistical data for Israel are supplied by and under the responsibility of the relevant Israeli authorities. The use of such data by the OECD is without prejudice to the status of the Golan Heights, East Jerusalem and Israeli settlements in the West Bank under the terms of international law.

Note by Turkey:

The information in this document with reference to "Cyprus" relates to the southern part of the Island. There is no single authority representing both Turkish and Greek Cypriot people on the Island. Turkey recognises the Turkish Republic of Northern Cyprus (TRNC). Until a lasting and equitable solution is found within the context of the United Nations, Turkey shall preserve its position concerning the "Cyprus issue".

Note by all the European Union Member States of the OECD and the European Union:

The Republic of Cyprus is recognised by all members of the United Nations with the exception of Turkey. The information in this document relates to the area under the effective control of the Government of the Republic of Cyprus.

(C) OECD 2014

Applications for permission to reproduce or translate all or part of this material should be made to: OECD Publishing, rights@oecd.org or by fax 33145249930. 


\title{
INVESTMENT TREATY LAW, SUSTAINABLE DEVELOPMENT AND RESPONSIBLE BUSINESS CONDUCT: A FACT FINDING SURVEY
}

\author{
by \\ Kathryn Gordon, Joachim Pohl and Marie Bouchard
}

\begin{abstract}
Investment treaty law - which is scattered over 3000 international investment agreements adopted over a period of 50 years - is a crucial but complex basis for regulating international investment flows. Investment treaties are often thought to be silent on investors' responsibilities to host societies and on their contributions to sustainable development. The present paper establishes a factual and statistical basis for understanding the relationship between investment treaty law and governments' ability to advance the sustainable development agenda and promote responsible business conduct. The paper presents survey results of 2107 investment treaties and 1113 treaty-based arbitration cases in order to shed light on how (if at all) labour, environmental, human rights and anti-corruption considerations are referred to in investment treaties and investor-state arbitration cases based on them.
\end{abstract}

Approved by Adrian Blundell-Wignall, Director, OECD Directorate for Financial and Enterprise Affairs

JEL codes: F23, F53, K11, K33

Keywords: investment treaties, labour law, environmental law, corruption, bribery, investor state arbitration, ISDS. 


\section{TABLE OF CONTENTS}

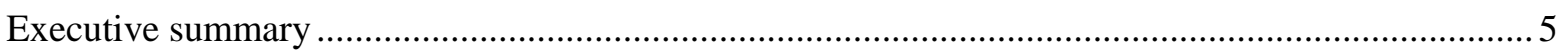

Investment treaty law, sustainable development and responsible business conduct:

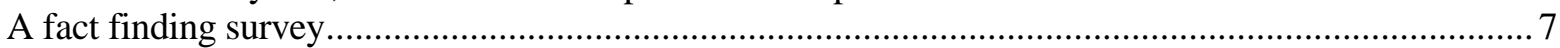

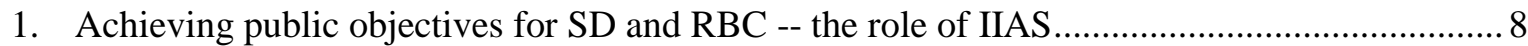

2. A large sample survey of investment treaty language dealing with $\mathrm{SD} / \mathrm{RBC}$ issues .................. 9

2.A. Patterns and evolution of the inclusion of SD/RBC language in investment treaties...... 10

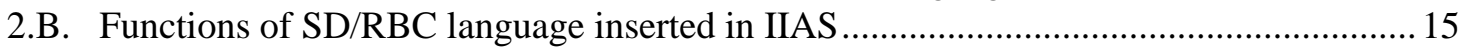

3. Investment treaty cases and SD/RBC - cross fertilisation or conflict?.....................................19

3.A. The general problématique - integrating bodies of law and resolving conflicts .............220

3.B. Reference to SD/RBC issues in investment arbitration cases ........................................22

3.C. References to international agreements relevant for $\mathrm{SD} / \mathrm{RBC}$ in investment

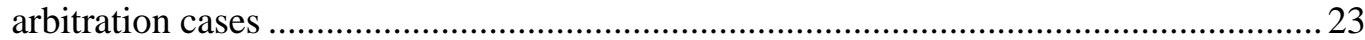

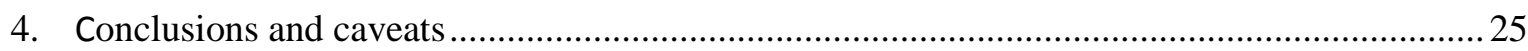

Annex 1. International investment agreements with SD/RBC language - detailed overview ............27

Annex 2. Examples of SD/RBC language in international investment agreements by function .........36

Annex 3. Use of RBC-related international agreements in investment arbitration cases.................... 48

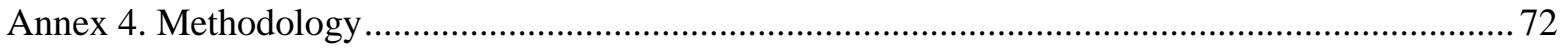

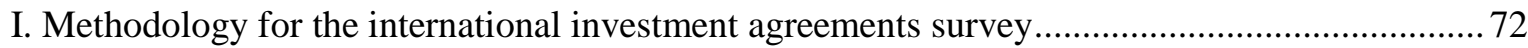

II. Methodology for the investment arbitration cases survey ....................................................... 72

\section{Tables}

1. Bilateral IIAs with language on SD/RBC issues: Country overview....................................... 13

2. Frequency of occurrence of SD/RBC concerns in relation to their function in bilateral IIAs .. 18

3. Environmental, Human Rights and Anti-corruption Agreements cited in investment arbitration cases.

\section{Figures}

1. Frequency of inclusion of $\mathrm{SD} / \mathrm{RBC}$ references in bilateral IIAs concluded in a given year......11

2. Evolution of the prevalence of references to SD/RBC concerns in bilateral IIAs .....................12

3. Evolution of the prevalence of references to SD/RBC concerns in BITs and bilateral FTAs/EPAs

4. Evolution of references to SD/RBC concerns in the treaty sample by the reference's

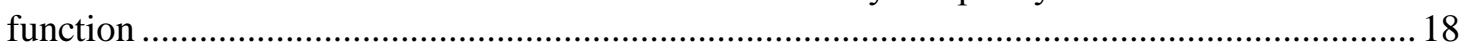

5. Evolution of SD/RBC references in IIAs concluded in a given year differentiated by the reference's function. 


\section{EXECUTIVE SUMMARY}

Investment treaty law - which is scattered over 3000 international investment agreements (henceforth, referred to as IIAs) adopted over a period of 50 years - is a crucial but complex basis for regulating international investment flows. The system is now under pressure, with criticisms from both traditional sources and free market think tanks. One criticism is that investment treaty law creates rights but not responsibilities for covered foreign investors. It is thought to be silent on their responsibilities to host societies and on their contributions to sustainable development. Some commentators are also concerned that investment treaty obligations may unduly limit host governments' ability to enact public policies needed to promote sustainable development and responsible business conduct.

The present paper establishes a preliminary, factual and statistical basis for considering key aspects of these issues. It explores the relationship between investment treaty law and governments' ability to advance the sustainable development agenda and promote responsible business conduct (henceforth, referred to as SD/RBC). The specific SD/RBC issues covered are environmental protection, labour conditions and standards, anti-corruption and human rights. The paper presents survey results of 2107 investment treaties and 1113 treaty-based arbitration cases to answer the following questions:

- Do governments use their IIAs to advance their SD/RBC agendas? More specifically, do they: 1) include treaty language aimed at preserving space for policy making in areas important to $S D / R B C$; 2) use investment treaties to raise investor awareness of major international instruments in the environmental, labour, anti-corruption and human rights fields and 3) include language in the IIAs that communicates directly to investors about $R B C$ ?

- Do arbitrators refer to $S D / R B C$ issues when adjudicating treaty-based investor-state disputes and do they refer to other international agreements that are of particular relevance to $S D / R B C$ when adjudicating these disputes in the context of investor state dispute settlement (henceforth, referred to as ISDS)?

The treaty survey provides the following responses to the first set of questions:

Inclusion of SD/RBC issues has become a dominant treaty practice in recent years. More than three-fourths of recently concluded IIAs (i.e. between 2008 and 2013) contain language on SD/RBC (mainly Free Trade Agreements with investment protection provisions) and virtually all of the investment treaties concluded in 2012 and 2013 include such language. Forty-seven of the fiftyfour countries covered by the survey have included some form of SD/RBC language in at least one of their treaties.

Older treaties without any SD/RBC language continue to dominate the treaty sample. Only $12 \%$ of the entire stock of IIAs contains language on these matters. The issue most often addressed being environmental protection (10\%), followed by labour standards (5.5\%), anti-corruption $(1.5 \%)$ and human rights $(0.5 \%)$. 
Treaty practice shows wide variation across countries, with no established pattern in this area. The treaty survey documents major variations across different countries' treaty practices, both with respect to their approach to the broad legal functions of SD/RBC language in IIAs and with respect to "micro" variations in the exact language used for a given type of treaty text. Major functions of such treaty language are, in the order of prevalence: (i) establishing the context and purpose of the treaty and setting forth basic $\mathrm{SD} / \mathrm{RBC}$ principles through preamble language; (ii) preserving policy space to enact public policies dealing with SC/RBC concerns; and (iii) not lowering standards, in particular not relaxing environmental and labour standards for the purpose of attracting investment. Generally, governments do not use these IIAs to communicate directly to companies on SD/RBC. No treaty-specific language on investor responsibility (aside from legality requirements for covered investments) was found in the sample and only 4 of the treaties surveyed specifically mention the OECD Guidelines for Multinational Enterprises.

The survey of investment treaty cases provides the following responses to the second set of questions:

Arbitrators frequently refer to issues and international agreements relating to $S D / R B C$. The thematic key word search of 1113 treaty-based decisions shows that $26 \%$ of these mention at least one $\mathrm{SD} / \mathrm{RBC}$ issue, the most common concern being environment, followed by corruption. Human rights come in a distant third. Labour conditions and standards do not appear to be referred to in any of the cases in the sample. The survey also shows that arbitrators often refer to international SD/RBC instruments when they consider them to be relevant. The agreement-based key word search documents references to 28 international SD/RBC instruments in the treaty-based decisions surveyed. Most common references are to the European Convention on Human Rights (cited in 27 different decisions), the International Convention on the Elimination of All Forms of Racial Discrimination (referred to in 8 decisions) and the Convention on the Prevention and Punishment of the Crime of Genocide (mentioned in 7 decisions).

The treaty survey and the investment treaty cases survey allow drawing the following preliminary conclusions:

State parties and arbitrators are starting to recognize the interface between investment treaty law and other bodies of international law of particular relevance for SD/RBC. The survey of investment treaties shows that inclusion of SD/RBC issues in IIAs has become the dominant trend in recent years, though there are large variations among countries in terms of practice. Likewise, the survey of treaty-based investment arbitration cases shows that arbitration panels refer fairly frequently to $\mathrm{SD} / \mathrm{RBC}$ issues and to related international agreements of relevance in their decisions. Thus, preliminary and partial evidence is provided in support of the view that both State parties to IIAs and investment arbitration tribunals are starting to consider the potential interactions between investment law and SD/RBC issues and related international instruments.

Caveats - including SD/RBC language in treaties will not contribute to achieve SD/RBC objectives if broader concerns in other substantive and procedural provisions remain. Interpretation and application of IIAs is based on the language they contain. Earlier OECD analysis has shown that substantive treaty commitments are broadly framed and that ISDS is generally 'lightly regulated'. Including SD/RBC language in investment treaties might therefore not yield full benefits if other treaty language does not succeed in providing incentives for improved public sector governance and attracting high quality investment. Governments will want to be mindful of the need to craft treaties that not only advance their objectives in relation to SD/RBC but that also include ISDS provisions that provide appropriate interpretive guidance to those charged with interpreting and applying the treaties. 


\title{
INVESTMENT TREATY LAW, SUSTAINABLE DEVELOPMENT AND RESPONSIBLE BUSINESS CONDUCT: A FACT FINDING SURVEY ${ }^{1}$
}

\author{
The Government of Japan and the Government of the Independent State of Papua New Guinea, \\ [...]
}

Recognising the importance of foreign investment for national development, economic growth and general welfare of the citizens [...]

Recognising that economic development, social development and environmental protection are interdependent and mutually reinforcing pillars of sustainable development and that cooperative efforts of the Contracting Parties to promote investment can play an important role in enhancing sustainable development;

Recognising also that these objectives can be achieved without relaxing health, safety and environmental measures of general application; [...]

Preamble of the Japan-Papua New Guinea BIT (2011)

Most governments can be assumed to be committed to the objective of promoting sustainable development (henceforth, referred to as SD) and responsible business conduct (henceforth, referred to as RBC). ${ }^{2}$ This paper explores a specific dimension of the broader challenge of making SD and RBC a reality in economies and in people's lives by looking at the role of investment treaty law in advancing these objectives. However, results from earlier OECD treaty surveys show that inclusion of these concerns in international investment agreements (henceforth, referred to as IIAs), as in the

1 This draft Working Paper serves as reference material for the Informal Ministerial Meeting on Responsible Business Conduct taking place in Paris on 26 June 2014. It was prepared by Kathryn Gordon, Joachim Pohl and Marie Bouchard in the Investment Division of the OECD Directorate for Financial and Enterprise Affairs. The opinions and views expressed and arguments employed herein are those of the authors and do not necessarily reflect or represent the official views of the OECD or of the governments of its member countries. The final version of this paper will be published as a Working Paper in the OECD Working Papers on International Investment series www.oecd.org/daf/inv/investment-policy/working-papers.htm.

2 The definition of RBC used here is conduct consistent with applicable laws and internationally recognised standards. $\mathrm{RBC}$ is a broad concept that focuses on two aspects of the business-society relationship: 1) positive contribution businesses can make to economic, environmental, and social progress with a view to achieving sustainable development, and 2) avoiding adverse impacts and addressing them when they do occur. See OECD, Responsible Business Conduct Matters - OECD Guidelines for Multinational Enterprises, OECD Publications, 2013, pp. 6-7. 
preamble of the Japan-Papua New Guinea BIT quoted above, remains rare. In general, until the recent past, governments have not tended to use IIAs to promote SD and $\mathrm{RBC}^{3}$.

The current study is aimed at taking stock of the inclusion of SD and RBC concerns in investment treaty law by updating and extending earlier of investment treaty practice in relation to $\mathrm{SD} / \mathrm{RBC}$ and providing a preliminary statistical survey of the degree to which treaty-based arbitration cases refer to these concerns.

The paper begins with a brief review of the role governments can play in fostering SD and RBC and, more particularly, of the use of IIAs in this regard (Section 1). It then turns to a large sample survey of treaty practice and examines how such issues as the protection of the environment, labour conditions and standards, the fight against corruption and human rights are handled in treaty texts (Section 2). The paper then explores statistically the occurrence of these same issues in investor state arbitration cases and the citation of international agreements relevant to SD/RBC therein (Section 3). The conclusions place caveats on these findings and highlight the importance of the adequate design of the investor state dispute settlement (henceforth, referred to as ISDS) that have been established as an enforcement mechanism for the vast majority of the IIAs' provisions (Section 4).

\section{Achieving public objectives for SD and RBC -- the role of IIAs}

$\mathrm{RBC}$ results from the efforts of the business community operating in a broader "ecosystem of responsibility"4. The summary report from the 2013 Global Forum on RBC states that "all actors not only enterprises - have a responsibility for building a healthy business environment. Governments cannot abdicate their responsibility for protecting internationally recognised fundamental rights and ensuring good governance, fair regulations, and transparency. Labour and civil society have to engage constructively to ensure accountability and provide a voice for the most disadvantaged." 5 Thus, business, labour and civil societies, as well as governments, all have a role in promoting SD and RBC.

In this broader "ecosystem of responsibility", government roles consist in developing and implementing a broad, public policy framework for the promotion of SD and RBC. The three main channels for government action in this area are:

- Developing domestic policies, including regulation, fiscal policy and law enforcement. If properly designed, the public policy framework can create appropriate incentives for firms (and others) to contribute to SD and RBC as well as appropriate disincentives for business actions that detract from such orientations. These policies need to be transparent, effective in achieving their stated aims and to avoid unwarranted disruption of economic activity or violations of the rights of people affected by them ${ }^{6}$.

3 See Kathryn Gordon and Monica Bose, "International Investment Agreements: A survey of Environmental, Labour and Anti-Corruption Issues", International Investment Law: Understanding Concepts and Tracking Innovations, OECD Publishing, 2008, pp. 135-240 and Kathryn Gordon and Joachim Pohl, "Environmental Concerns in International Investment Agreements - A Survey”, OECD Working Papers on International Investment, No. 2011/01, OECD Publishing.

4 See OECD, Global Forum on Responsible Business Conduct, Summary Report, June 2013, pp. 23-24.

5 OECD, Global Forum on Responsible Business Conduct, Summary Report, June 2013, p. 24.

6 David Gaukrodger and Kathryn Gordon, "Investor-State Dispute Settlement: A Scoping Paper for the Investment Policy Community", OECD Working Papers on International Investment, No. 2012/03, OECD Publishing. 
- Participating in international cooperation processes that develop common regional or global goals and standards on issues of particular relevance to SD/RBC, such as the OECD and UN processes relating to the protection of the environment, health, labour conditions and standards, the fight against corruption and human rights.

- Communicating directly to firms about their role in supporting SD and adopting RBC approaches. Governments can use alternative channels of communication (other than laws governing business activities) to clarify their positions and expectations regarding SD and RBC. This can take place in a variety of ways, including the development of RBC instruments at the national and international levels. The OECD Guidelines for Multinational Enterprises are an example of a formal platform for this type of interaction between governments and firms.

Investment treaty law influences or potentially influences policies relating to all three of these channels for government promotion of SD/RBC. Specifically, governments can craft treaty language in order to:

- Preserving policy space. Investment treaties are designed to promote investment protection for covered foreign investors. However, through such treaty commitments as 'national treatment' and 'fair and equitable treatment', they can also have an impact on the domestic policy making process. Governments wishing to promote SD and RBC will want to be mindful of the need to include provisions preserving their domestic policy making prerogatives in their IIAs, while also recognising the value of basic investment treaty principles (e.g. non-discrimination) for the design and enforcement of SD/RBC policies. The treaty survey presented in Section 2 documents the evolution of treaty language that attempts to preserve space for pursuing $\mathrm{SD} / \mathrm{RBC}$ policies in a domestic context and shows that this a common type of SD/RBC language in recently concluded IIAs.

- Promoting international SD/RBC instruments. These instruments (for example, multilateral environmental agreements and anti-bribery conventions) coexist with IIAs and are implemented in parallel with investment treaty law. They formalise international thinking and undertakings on the responsibilities of states and other actors (notably enterprises) in such fields as environment, labour, anti-corruption and human rights. Thus, many of them provide inputs relevant for public and private decisions relating to international investment. The survey of treaty-based arbitration cases in Section 3 examines the frequency with which these other international agreements are referred to in investment treaty decisions.

- Communicating directly to investors on SD/RBC. IIAs could potentially contribute to the promotion of $\mathrm{SD} / \mathrm{RBC}$ by including language on investor responsibility. Possible options range from creating obligations for investors in IIAs to using the treaties to promote SD/RBC instruments as the OECD Guidelines for Multinational Enterprises or the UN Guiding Principles on Business and Human Rights. The treaty survey in Section 2 shows that inclusion of such references in IIAs is very rare indeed.

\section{A large sample survey of investment treaty language dealing with SD/RBC issues}

IIAs contain commitments on investment protection. They also increasingly include language on how these commitments are to be integrated with other public policy goals and processes. This section explores statistically whether and how investment treaties include language aimed at integrating the goals of investment protection and the promotion of SD and RBC. 
The OECD-hosted investment policy community has on several earlier occasions surveyed investment treaty practice, both for issues of particular relevance to SD and $\mathrm{RBC}$ and in relation to dispute settlement provisions. ${ }^{7}$ An initial study carried out in 2007 surveyed references to environmental, labour and anti-corruption issues in IIAs. ${ }^{8}$ An updated and enhanced study of treaty practice relating to environmental issues followed in $2010 .{ }^{9}$

The present study further updates and extends the earlier studies by expanding the issue coverage to four SD/RBC related areas (environment, labour, human rights and anti-corruption) and the treaty coverage to 2,094 bilateral treaties and 13 multilateral treaties. The sample includes all of the investment treaties that countries invited to participate in OECD-hosted investment dialogue - that is, 54 countries ${ }^{10}$ plus the European Commission - have concluded with any other country, provided that the full text of the treaty was electronically available in early $2014 .^{11}$ This sample of 2,107 treaties covers more than $70 \%$ of the global investment treaty population. ${ }^{12}$

The survey restricts itself to a statistical characterisation of the frequency, kind and extent of language referring to SD/RBC concerns inserted in IIAs and of the evolution of the inclusion of such language over time. It does not analyse the legal significance or consequences that this content might have, although it does provide a starting point for such analysis.

\section{A. Patterns and evolution of the inclusion of SD/RBC language in investment treaties}

Treaty language referring to $S D / R B C$ concerns is rare, but its frequency has progressively increased in recent years. Figure 1 shows the percentage of treaties concluded in a given year that contain such references, distinguished by subject area. Figure 2 shows the prevalence and evolution of such references in the entire treaty sample. The survey indicates that only 252 IIAs, or $12.1 \%$ of the overall sample, contain SD/RBC references, but that more than $75 \%$ of treaties signed between 2008 and 2013 -- mainly Free Trade Agreements (henceforth, FTAs) with investment chapters - refer to at least one of the four RBC-related issues. Figures 1 and 2 show that treaty language referring to $\mathrm{SD} / \mathrm{RBC}$ issues remained rare until 1994, when the inclusion of SD/RBC language in IIAs started to evolve more rapidly.

7 Several studies were dedicated to approaches to integrating openness to foreign investment with national security. For the complete work accomplished in this area, visit www.oecd.org/daf/investment/foi.

Kathryn Gordon and Monica Bose, "International Investment Agreements: A survey of Environmental, Labour and Anti-Corruption Issues", International Investment Law: Understanding Concepts and Tracking Innovations, OECD Publishing, 2008, pp. 135-240.

Kathryn Gordon and Joachim Pohl, "Environmental Concerns in International Investment Agreements - A Survey”, OECD Working Papers on International Investment, No. 2011/01, OECD Publishing.

Argentina, Australia, Austria, Belgium, Brazil, Bulgaria, Canada, Chile, China, Colombia, Costa Rica, Czech Republic, Denmark, Egypt, Estonia, Finland, France, Germany, Greece, Hungary, Iceland, India, Indonesia, Ireland, Israel, Italy, Japan, Jordan, Korea, Latvia, Lithuania, Luxembourg, Malaysia, Mexico, Morocco, Netherlands, New Zealand, Norway, Peru, Poland, Portugal, Romania, Russian Federation, Saudi Arabia, Slovakia, Slovenia, South Africa, Spain, Sweden, Switzerland, Tunisia, Turkey, United Kingdom, and United States.

A description of the methodology, the sources used, and the IIAs included in the sample of the study is available in Annex 4.

According to UNCTAD data, there were, as of 15 November 2013, globally 2,866 BITs and approximately 345 other IIAs. See WTO, OECD, UNCTAD, $10^{\text {th }}$ Report on G20 Trade and Investment Measures (Mid-May 2013 to Mid-November 2013), 18 December 2013, p.59. 
Different SD/RBC concerns have been introduced in treaty language at different times. The survey shows that the inclusion in IIAs of each of the four RBC-related issues surveyed varies in time. Environmental concerns were the first $\mathrm{SD} / \mathrm{RBC}$ issue to be mentioned in a treaty, appearing in a 1985 China-Singapore BIT. ${ }^{13}$ Labour issues then appeared five years later, in $1990^{14}$ and anti-corruption issues fifteen years later, in $2000^{15}$. The first mention of human rights concerns occurred in a 2002 treaty. ${ }^{16}$ The order in which the SD/RBC concerns first appeared in IIAs also corresponds to the order of frequency of occurrence. Among the four RBC-related issues considered in the survey, protection of the environment is found with the highest frequency. Figures 1 and 2 respectively show that $75.5 \%$ of recent treaties (i.e. treaties signed between 2008 and 2013) and about $10 \%$ of the entire sample mention environmental concerns. Environmental language is followed distantly by inclusion of treaty language referring to labour standards and conditions, the fight against corruption, and human rights.

Figure 1. Frequency of inclusion of SD/RBC references in bilateral IIAs concluded in a given year (3 year moving average)

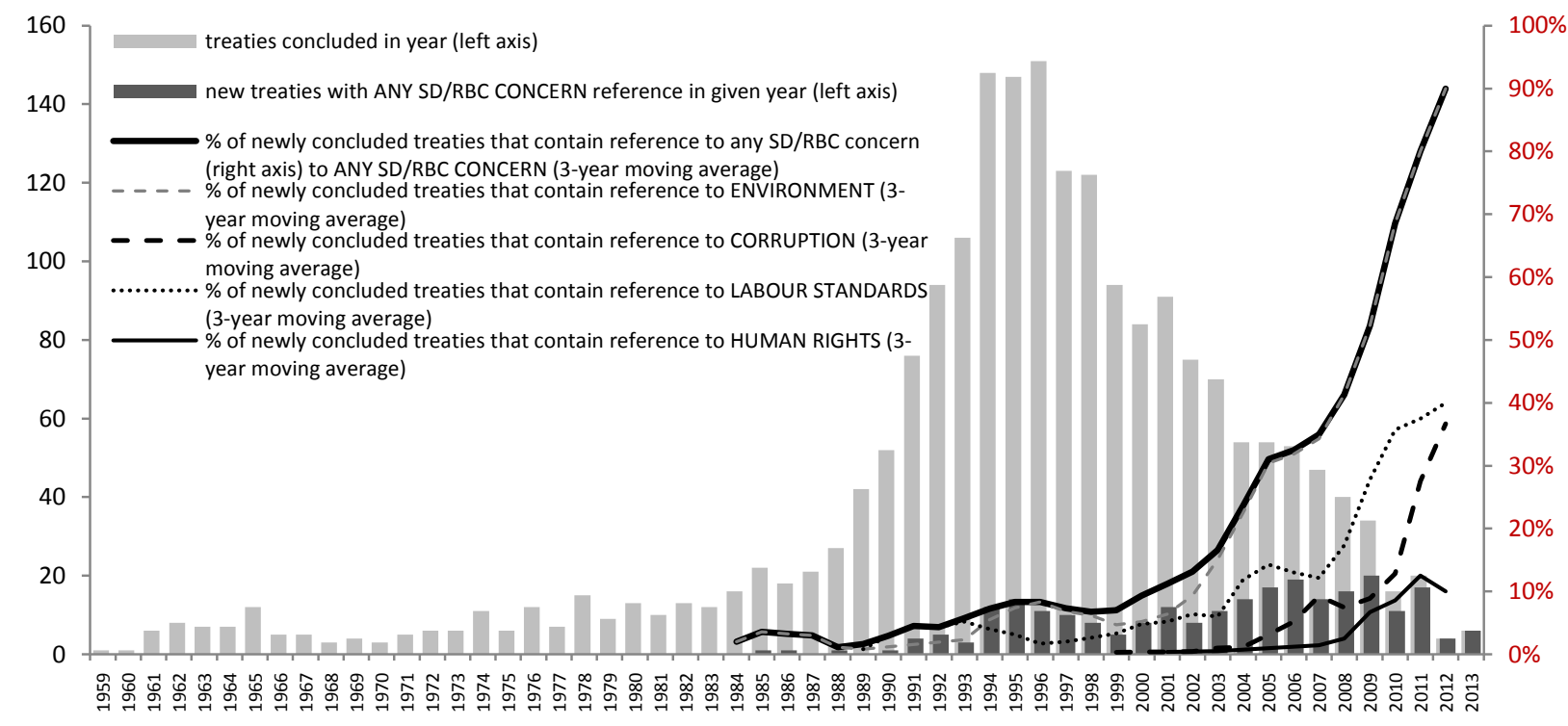

13 China-Singapore BIT (1985), Article 11 "Prohibitions and Restrictions": "[t]he provisions of this Agreement shall not in any way limit the right of either Contracting Party to apply prohibitions or restrictions of any kind or take any other action which is directed to the protection of its essential security interests, or to the protection of public health or the prevention of diseases and pests in animals or plants".

14 Poland-United States BIT (1990), Preamble: “[t]he United States of America and the Republic of Poland [...]; Recognizing that the development of business and economic ties can contribute to the well-being of workers in both countries and promote respect for fundamental worker rights; $[\ldots]$ Agree as follows: [...]".

15 Austria-Uzbekistan BIT (2000), Article 25 "Nullification": "(1) Either Party to the dispute may request the annulment of an award, in whole or in part, on one or more of the following grounds, that: [...] (c) there was corruption on the part of a member of the tribunal or on the part of a person providing decisive expertise or evidence [...]".

Austria-Malta BIT (2002), Article 18 “Scope, Consultations, Mediation and Conciliation”: “[...] (2) The application of the European Convention on Human Rights shall not be excluded". 
Legacy effects regarding the inclusion of language referring to $S D / R B C$ are evident in the treaty sample. The survey shows that the majority of recent treaties contain SD/RBC language, but that the inclusion of such language is only rarely found in the overall sample. This attests to the strong 'legacy' effects in the treaty production process. In other words, older approaches to treaty practice live on in older treaties that have not been renegotiated, presumably due to the high cost of treaty renegotiation, and that are still in force due to the length of their validity periods. ${ }^{17}$ Treaty drafters will want to be mindful of these long-lasting effects as they draft IIAs and to craft treaty provisions that allow adaption to changing circumstances and emerging issues.

Figure 2. Evolution of the prevalence of references to SD/RBC concerns in bilateral IIAs

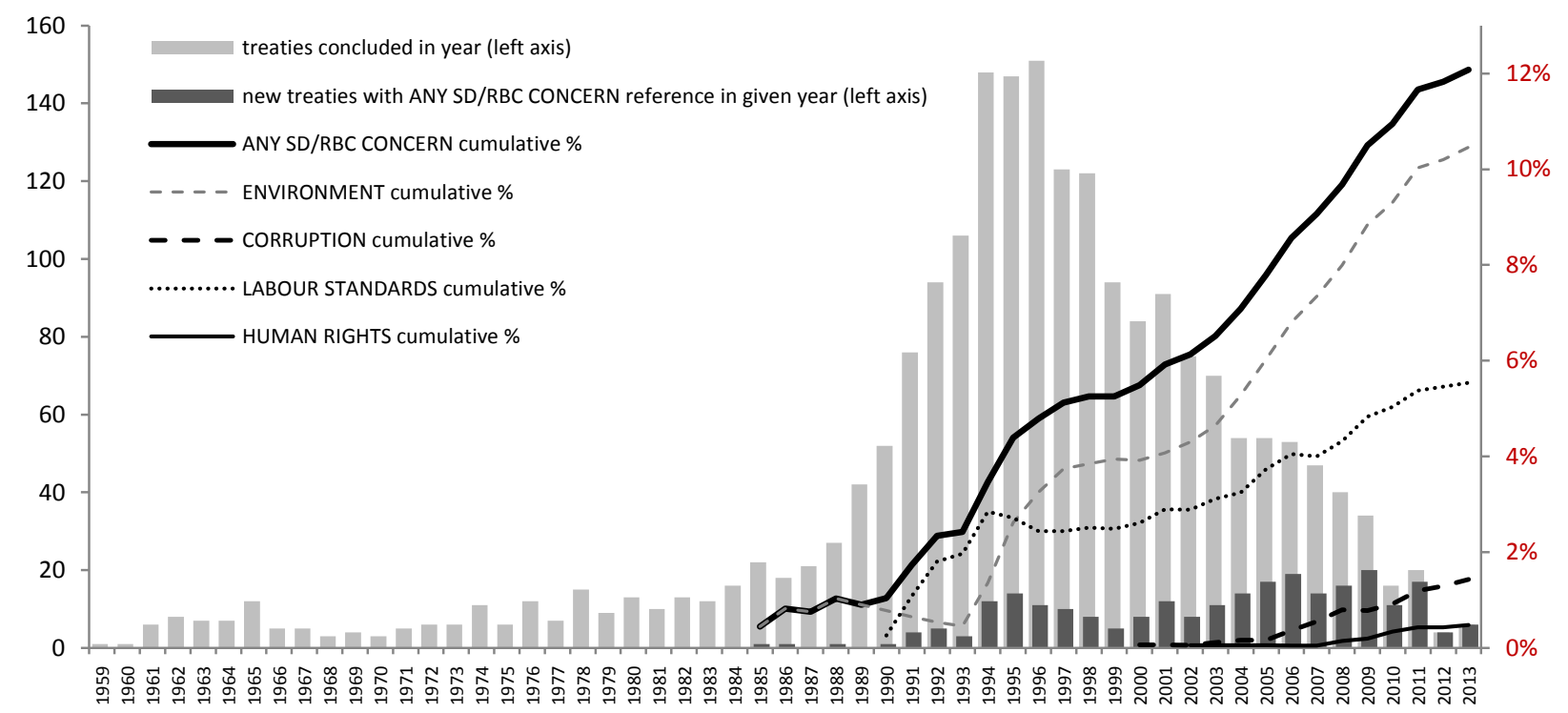

Countries vary significantly in their approach to including SD/RBC language in investment treaties. Table 1 shows that, overall, 47 of the 54 countries covered by the survey have included $\mathrm{SD} / \mathrm{RBC}$ language in at least one of their IIAs. Some countries only very occasionally include such language. For example, Germany and the United Kingdom have just 2 treaties each with references to $\mathrm{SD} / \mathrm{RBC}$ concerns out of 149 and 98 treaties, respectively. Countries with relatively high propensities to include such language include: New Zealand (89\% of its treaties), Canada (82\% of its treaties), the United States (74\%), Japan (71\%), and Colombia (60\%). The specific treaty language used to frame specific issues also varies (e.g. in relation to the specific language used to describe lists of ILO core labour standards ${ }^{18}$ ).

\footnotetext{
17 For an overview of the validity periods contained in IIAs, see Joachim Pohl, "Temporal Validity of International Investment Agreements: a Large Sample Survey of Treaty Provisions", OECD Working Papers on International Investment, No. 2013/04, OECD Publishing.

See the lists of core labour standards in Annex 2 section (vii).
} 
Table 1. Bilateral IIAs with language on SD/RBC issues: Country overview

\begin{tabular}{|c|c|c|c|c|c|}
\hline Country & $\begin{array}{l}\text { No. of bilateral } \\
\text { IIAs in the } \\
\text { sample }\end{array}$ & $\begin{array}{l}\text { Number of } \\
\text { bilateral IIAs } \\
\text { that contain } \\
\text { references to } \\
\text { SD/RBC } \\
\text { concerns }\end{array}$ & $\begin{array}{l}\text { Percentage of } \\
\text { bilateral IIAs } \\
\text { that refer to } \\
\text { SD/RBC } \\
\text { concerns }\end{array}$ & $\begin{array}{l}\text { First occurrence } \\
\text { of a reference } \\
\text { to SD/RBC } \\
\text { concerns in a } \\
\text { bilateral IIA in } \\
\text { the sample }\end{array}$ & $\begin{array}{l}\text { Percentage of } \\
\text { bilateral IIAs } \\
\text { that contain } \\
\text { SD/RBC } \\
\text { reference since } \\
\text { first occurrence }\end{array}$ \\
\hline Argentina & 59 & 2 & $3 \%$ & 1991 & $14 \%$ \\
\hline Australia & 26 & 5 & $19 \%$ & 2004 & $83 \%$ \\
\hline Austria & 63 & 20 & $32 \%$ & 1996 & $45 \%$ \\
\hline Belgium/Luxembourg & 93 & 18 & $19 \%$ & 2004 & $78 \%$ \\
\hline Brazil & 9 & 0 & $0 \%$ & - & - \\
\hline Bulgaria & 40 & 1 & $3 \%$ & 1992 & $3 \%$ \\
\hline Canada & 39 & 32 & $82 \%$ & 1994 & $100 \%$ \\
\hline Chile & 59 & 8 & $14 \%$ & 1996 & $24 \%$ \\
\hline China & 107 & 7 & $7 \%$ & 1985 & $7 \%$ \\
\hline Colombia & 15 & 9 & $60 \%$ & 1994 & $60 \%$ \\
\hline Costa Rica & 22 & 4 & $18 \%$ & 1994 & $21 \%$ \\
\hline Czech Republic & 80 & 6 & $8 \%$ & 1991 & $9 \%$ \\
\hline Denmark & 50 & 0 & $0 \%$ & - & - \\
\hline Egypt & 70 & 2 & $3 \%$ & 1996 & $5 \%$ \\
\hline Estonia & 21 & 2 & $10 \%$ & 1994 & $18 \%$ \\
\hline Finland & 78 & 26 & $33 \%$ & 2000 & $67 \%$ \\
\hline France & 104 & 1 & $1 \%$ & 1997 & $3 \%$ \\
\hline Germany & 149 & 2 & $1 \%$ & 1995 & $3 \%$ \\
\hline Greece & 37 & 0 & $0 \%$ & - & - \\
\hline Hungary & 57 & 1 & $2 \%$ & 1995 & $5 \%$ \\
\hline Iceland & 5 & 1 & $20 \%$ & 2007 & $100 \%$ \\
\hline India & 79 & 23 & $29 \%$ & 1995 & $30 \%$ \\
\hline Indonesia & 67 & 2 & $3 \%$ & 1997 & $6 \%$ \\
\hline Ireland & 1 & 0 & $0 \%$ & - & - \\
\hline Israel & 21 & 0 & $0 \%$ & - & - \\
\hline Italy & 71 & 1 & $1 \%$ & 1995 & $3 \%$ \\
\hline Japan & 31 & 22 & $71 \%$ & 2002 & $100 \%$ \\
\hline Jordan & 34 & 7 & $21 \%$ & 1997 & $32 \%$ \\
\hline Korea & 101 & 12 & $12 \%$ & 1996 & $20 \%$ \\
\hline Latvia & 29 & 3 & $10 \%$ & 1995 & $18 \%$ \\
\hline Lithuania & 34 & 2 & $6 \%$ & 1998 & $17 \%$ \\
\hline Malaysia & 41 & 2 & $5 \%$ & 2005 & $67 \%$ \\
\hline Mexico & 37 & 13 & $35 \%$ & 1994 & $35 \%$ \\
\hline Morocco & 47 & 1 & $2 \%$ & 2004 & $10 \%$ \\
\hline Netherlands & 107 & 7 & $7 \%$ & 2001 & $23 \%$ \\
\hline New Zealand & 9 & 8 & $89 \%$ & 1988 & $89 \%$ \\
\hline Norway & 14 & 0 & $0 \%$ & - & - \\
\hline Peru & 43 & 14 & $33 \%$ & 2005 & $100 \%$ \\
\hline Poland & 54 & 1 & $2 \%$ & 1990 & $2 \%$ \\
\hline Portugal & 54 & 0 & $0 \%$ & - & - \\
\hline Romania & 84 & 4 & $5 \%$ & 1992 & $7 \%$ \\
\hline Russian Federation & 43 & 3 & $7 \%$ & 1995 & $8 \%$ \\
\hline
\end{tabular}




\begin{tabular}{|c|c|c|c|c|c|}
\hline Country & $\begin{array}{l}\text { No. of bilateral } \\
\text { IIAs in the } \\
\text { sample }\end{array}$ & $\begin{array}{l}\text { Number of } \\
\text { bilateral IIAs } \\
\text { that contain } \\
\text { references to } \\
\text { SD/RBC } \\
\text { concerns }\end{array}$ & $\begin{array}{l}\text { Percentage of } \\
\text { bilateral IIAs } \\
\text { that refer to } \\
\text { SD/RBC } \\
\text { concerns }\end{array}$ & $\begin{array}{l}\text { First occurrence } \\
\text { of a reference } \\
\text { to SD/RBC } \\
\text { concerns in a } \\
\text { bilateral IIA in } \\
\text { the sample }\end{array}$ & $\begin{array}{l}\text { Percentage of } \\
\text { bilateral IIAs } \\
\text { that contain } \\
\text { SD/RBC } \\
\text { reference since } \\
\text { first occurrence }\end{array}$ \\
\hline Saudi Arabia & 16 & 1 & $6 \%$ & 2013 & $100 \%$ \\
\hline Slovakia & 35 & 2 & $6 \%$ & 2010 & $100 \%$ \\
\hline Slovenia & 35 & 2 & $6 \%$ & 2001 & $22 \%$ \\
\hline South Africa & 46 & 1 & $2 \%$ & 1995 & $2 \%$ \\
\hline Spain & 69 & 1 & $1 \%$ & 2007 & $4 \%$ \\
\hline Sweden & 68 & 3 & $4 \%$ & 1995 & $8 \%$ \\
\hline Switzerland & 121 & 11 & $9 \%$ & 1995 & $18 \%$ \\
\hline Tunisia & 34 & 1 & $3 \%$ & 2012 & $100 \%$ \\
\hline Turkey & 78 & 1 & $1 \%$ & 2011 & $4 \%$ \\
\hline United Kingdom & 98 & 2 & $2 \%$ & 2006 & $67 \%$ \\
\hline United States & 54 & 40 & $74 \%$ & 1990 & $93 \%$ \\
\hline
\end{tabular}

IIAs with language referring to SD/RBC concerns frequently mention several issues or raise one issue in several ways. The survey shows that language referring to $\mathrm{SD} / \mathrm{RBC}$ issues tends to be concentrated in a few IIAs. ${ }^{19}$ In the entire sample, 377 references to the four SD/RBC concerns have been identified (not counting multiple references to the same issue in the same treaty), but these references are concentrated in only 252 treaties. Also, SD/RBC treaty language varies from brief (just a few words) ${ }^{20}$ references to quite extensive texts (ranging up to several pages). ${ }^{21}$

Different treaty practices for non-BITs IIAs as opposed to BITs. The survey shows that non-BIT IIAs include language referring to SD/RBC concerns much more frequently than BITs do. Only $10 \%$ of the 2,042 BITs contain such language, as compared with $96 \%$ of the 50 non-BIT treaties (mainly FTAs and Economic Partnership Agreements -- henceforth, referred to as EPAs -- with investment protection provisions). The higher frequency of inclusion of such language in FTAs and EPAs partly explains the sizeable increase of the frequency of references in IIAs concluded recently. Figure 3 shows how the frequency of SD/RBC references has evolved for all bilateral IIAs as regards the protection of the environment and the fight against corruption. It indicates that, although the share of non-BIT IIAs in the sample is very small, the frequent inclusion therein of language referring to $\mathrm{SD} / \mathrm{RBC}$ concerns, and in particular to the protection of the environment, contributes significantly to lifting the overall frequency of such references in the sample.

19 For an overview of the different SD/ RBC issues covered by each IIA including SD/RBC language, see Annex 1.

See, for instance, the preamble of the Switzerland-Kosovo BIT (2011): « [1] Conseil federal suisse et le Gouvernement de la République du Kosovo, [...] visant à encourager les investisseurs au respect des normes et principes de responsabilité sociale des entreprises internationalement reconnus, sont convenus de ce qui suit: $[\ldots] »$.

See, for instance, the Peru-United States FTA (2006) which contains full chapters on labour and environment, both spanning over several pages. 
Figure 3. The prevalence of references to SD/RBC concerns in BITs and bilateral FTAs/EPAs

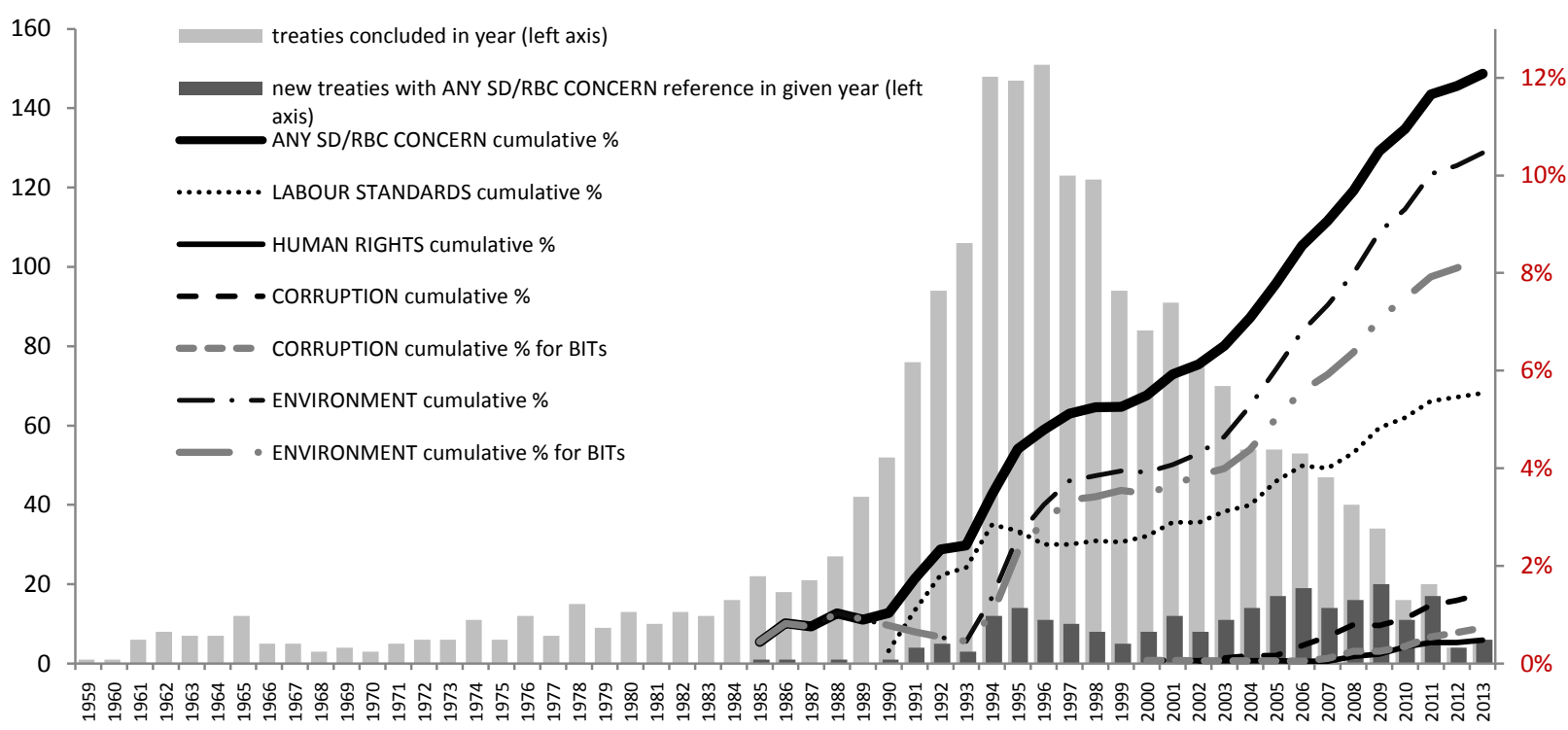

The approach to including SD/RBC language in multilateral investment agreements differs from treaty to treaty. Six of the 13 multilateral treaties covered by the survey contain language referring to $\mathrm{SD} / \mathrm{RBC}$ issues. In some of these treaties, the provisions including SD/RBC language are very detailed. Other treaties only contain brief references to such issues. While all six of the multilateral treaties with the SD/RBC language include language on environmental protection, only 4 of them refer to labour standards and conditions, 2 to the fight against corruption and 1 to human rights. The most recently concluded agreements tend to contain more language referring to $\mathrm{SD} / \mathrm{RBC}$ concerns than the older ones.

\section{B. Functions of SD/RBC language inserted in IIAs}

The different types of treaty language referring to SD/RBC can be categorised by their function and purpose in the treaty. ${ }^{22}$ Among the 377 references to SD/RBC concerns that have been identified in 252 bilateral IIAs, ${ }^{23}$ nine different approaches can be distinguished, testifying to the broad variation of the aim of these references. ${ }^{24}$ In the order of frequency of their occurrence, these language categories are:

- Preamble language. This type of language is found in 154 of the treaties surveyed (or $7.4 \%$ of the sample). Such references can be found with respect to the protection of the environment, labour conditions and standards, the fight against corruption and human rights. Although preamble language does not create binding treaty commitments, it is nevertheless important inasmuch as it helps to clarify the object and purpose of the treaty as well as the

This categorisation necessarily implies some degree of interpretation of the clauses. This interpretation is made only to reduce the complexity of the subject matter for the purpose of this study. As the following detailed presentation shows, the lines between these categories are sometimes uncertain and can lead to overlaps.

For this count, any given SD/RBC concern has been counted once per treaty only, even if it is approached in different functions. Multilateral IIAs have not been included in the count.

For detailed examples of treaty language for each of these categories, see Annex 2. 
broader context relevant for interpreting the treaty. As such, preamble language can provide essential inputs to the treaty interpretation process.

- Language on preserving policy space. This kind of provision, which aims at preserving policy space for regulating in the public interest, is found in $7 \%$ of the IIAs surveyed - or 146 treaties. Most of these references are specific to environmental concerns.

- Not lowering standards. This type of language, which seeks to discourage loosening of environmental or labour regulations in order to attract investment, is included in 82 of the treaties surveyed (or 3.9\% of the sample). This language is generally inserted in the main body of the treaty but it also appears in the preamble in some IIAs.

- Language establishing that, in general, environmental measures taken in order to protect public welfare objectives do not constitute indirect expropriation. This kind of provision, which has similar functions as provisions on preserving policy space, establishes that, in general, non-discriminatory regulatory actions taken in order to protect public welfare objectives, such as the environmental protection, do not constitute indirect expropriation. They are contained in 54 of the treaties surveyed (or $2.6 \%$ of the sample).

- Commitment to cooperate on SD/RBC matters language. This type of language, in which treaty partners commit to cooperate on such matters as the environment, the fight against corruption, or labour conditions and standards are found in 35 treaties, or $1.7 \%$ of the sample.

- Language establishing a relation between SD/RBC matters and ISDS. This type of provision -- contained in 31 treaties -- links SD/RBC concerns with the IIA's ISDS mechanism. In most of these cases, it provides that specific expertise be made available to the tribunal, through recourse to experts. ${ }^{25}$ Two IIAs contain language establishing different kind of relations: one excludes claims based on obligations undertaken in accordance with the treaty's environmental and labour provisions from $\operatorname{ISDS}^{26}$ and the other allows a party to a dispute to request annulment of the award if a member of the tribunal or an expert or witness was found to be corrupt. ${ }^{27}$

- Language on maintaining or implementing internationally recognized standards. Such language generally refers to standards that the treaty partners commit to implement with respect to the fight against corruption or the protection and implementation of labour conditions and standards. It is found in 28 IIAs, or $1.3 \%$ of the treaty sample. Examples of such language include the respect of certain internationally recognized labour standards

In 28 IIAs surveyed, recourse to experts is required for environmental issues. See, for instance, Article 42 of the Canada-Jordan BIT (2009) entitled "Expert Reports": "[w]ithout prejudice to the appointment of other kinds of experts where authorized by the applicable arbitration rules, a Tribunal, at the request of a disputing party or, unless the disputing parties disapprove, on its own initiative, may appoint one or more experts to report to it in writing on any factual issue concerning environmental, health, safety or other scientific matters raised by a disputing party in a proceeding, subject to such terms and conditions as the disputing parties may agree."

Articles VII(5) and VIII(4) of the Belgium/Luxembourg-Colombia BIT (2009): "[t]he dispute settlement mechanisms under articles XII and XIII of this Agreement shall not apply to any obligation undertaken in accordance with [articles VII on environment and VIII on labour]".

Article 25(c) of the Austria-Uzbekistan BIT (2000) entitled "Nullification": "(1) Either Party to the dispute may request the annulment of an award, in whole or in part, on one or more of the following grounds, that: [...] (c) there was corruption on the part of a member of the tribunal or on the part of a person providing decisive expertise or evidence [...]". 
(though core labour standards are not always expressed in the same way) ${ }^{28}$ or criminal law requirements with respect to the fight against corruption ${ }^{29}$. Some treaty language on corruption is almost identical to the text of the OECD Convention on Combating Bribery of Foreign Public Officials in International Business Transactions.

- Language establishing commitments to act in the fight against corruption. This kind of language, which expresses the treaty partners' commitments to take measures with respect to the fight against corruption, is contained in 16 treaties in the sample, or $0.8 \%$ of the treaties surveyed.

- Language encouraging the respect of $R B C$ standards. With this language, treaty partners commit to encouraging enterprises to respect RBC standards; it is found in 9 treaties, or $0.4 \%$ of the sample. These commitments are either mentioned generically, most often in conjunction with a list of subject areas they should cover, ${ }^{30}$ or reference is made specifically to the OECD Guidelines for Multinational Enterprises. ${ }^{31}$

Table 2 shows the frequency of these different approaches to SD/RBC language in IIAs.

$28 \quad$ Note that core labour standards are not always formulated in identical ways (see Annex 2, subsection (vii)). See, also Article 18.1 of the Chile-United States FTA (2003) entitled "Statement of Shared Commitment": "1. The Parties reaffirm their obligations as members of the International Labor Organization (ILO) and their commitments under the ILO Declaration on Fundamental Principles and Rights at Work and its Follow-up (1998). Each Party shall strive to ensure that such labor principles and the internationally recognized labor rights set forth in Article 18.8 are recognized and protected by its domestic law. [...]",

See, for instance, Article 21.6 of the Korea-United States FTA (2007) entitled "Anti-Corruption": "1. The Parties reaffirm their resolve to eliminate bribery and corruption in international trade and investment. 2. Each Party shall adopt or maintain the necessary legislative or other measures to establish that it is a criminal offense under its law, in matters affecting international trade or investment, for: (a) a public official of the Party or a person who performs public functions for the Party intentionally to solicit or accept, directly or indirectly, any article of monetary value or other benefit, such as a favor, promise, or advantage, for himself or for another person, in exchange for any act or omission in the performance of his public functions [...]".

See, for instance, Article 16 of the Canada-Benin BIT (2013) entitled "Corporate Social Responsibility": "[e]ach Contracting Party should encourage enterprises operating within its territory or subject to its jurisdiction to voluntarily incorporate internationally recognized standards of corporate social responsibility in their practices and internal policies, such as statements of principle that have been endorsed or are supported by the Contracting Parties. These principles address issues such as labour, the environment, human rights, community relations and anti-corruption”.

See, for instance, the preamble of the Austria-Kosovo BIT (2010): "[t]he GOVERNMENT OF THE REPUBLIC OF AUSTRIA and the GOVERNMENT OF THE REPUBLIC OF KOSOVO, [...] EXPRESSING their belief that responsible corporate behaviour, as incorporated in the OECD Guidelines for Multinational Enterprises, can contribute to mutual confidence between enterprises and host countries; [...] HAVE AGREED AS FOLLOWS: [...]”. 
Table 2. Frequency of occurrence of SD/RBC concerns in relation to their function in bilateral IIAs (as a percentage of the total treaty sample)

\begin{tabular}{|c|c|c|c|c|c|}
\hline & $\begin{array}{l}\text { Any } \\
\text { issue }\end{array}$ & Environment & Labour & Corruption & $\begin{array}{l}\text { Human } \\
\text { Rights }\end{array}$ \\
\hline Any function & $12.1 \%$ & $10.5 \%$ & $5.5 \%$ & $1.4 \%$ & $0.5 \%$ \\
\hline Preamble language & $7.4 \%$ & $5.4 \%$ & $4.6 \%$ & $0.6 \%$ & $0.5 \%$ \\
\hline Reserving policy space & $7.0 \%$ & $7.0 \%$ & - & - & - \\
\hline Not lowering standards & $3.9 \%$ & $3.7 \%$ & $1.8 \%$ & - & - \\
\hline $\begin{array}{l}\text { Indirect expropriation - non-discriminatory } \\
\text { environmental regulation do not constitute indirect } \\
\text { expropriation }\end{array}$ & $2.6 \%$ & $2.6 \%$ & - & - & - \\
\hline Commitment to cooperate on SD/RBC matters & $1.7 \%$ & $1.1 \%$ & $1.2 \%$ & $0.4 \%$ & - \\
\hline ISDS relation to SD/RBC issues & $1.5 \%$ & $1.3 \%$ & $0.1 \%$ & $0.0 \%$ & - \\
\hline Commitment to internationally recognized standards & $1.3 \%$ & - & $1.2 \%$ & $0.5 \%$ & - \\
\hline Commitment to act in the fight against corruption & $0.8 \%$ & - & - & $0.8 \%$ & - \\
\hline $\begin{array}{l}\text { Reference to RBC standards (e.g. the OECD } \\
\text { Guidelines) }\end{array}$ & $0.4 \%$ & $0.4 \%$ & $0.4 \%$ & $0.3 \%$ & $0.3 \%$ \\
\hline
\end{tabular}

The frequency of the nine categories is variable and the evolution of their inclusion in IIAs has also not been homogenous in time. Figure 4 shows how the frequencies of provisions with specific functions in the overall treaty sample at the end of a given year have evolved over time. It indicates that references to $\mathrm{SD} / \mathrm{RBC}$ concerns in preambles and language that seeks to preserve policy space are the functions that first appeared in IIAs and the most common categories of language. Commitments to not lower standards, which were first introduced in a treaty in $1994,{ }^{32}$ remain rare. Other categories of $\mathrm{SD} / \mathrm{RBC}$ language (such as commitments to act in the fight against corruption or references to RBC standards) developed later and their frequency in the overall sample remains low.

Figure 4. Evolution of references to SD/RBC concerns in the treaty sample by the reference's function

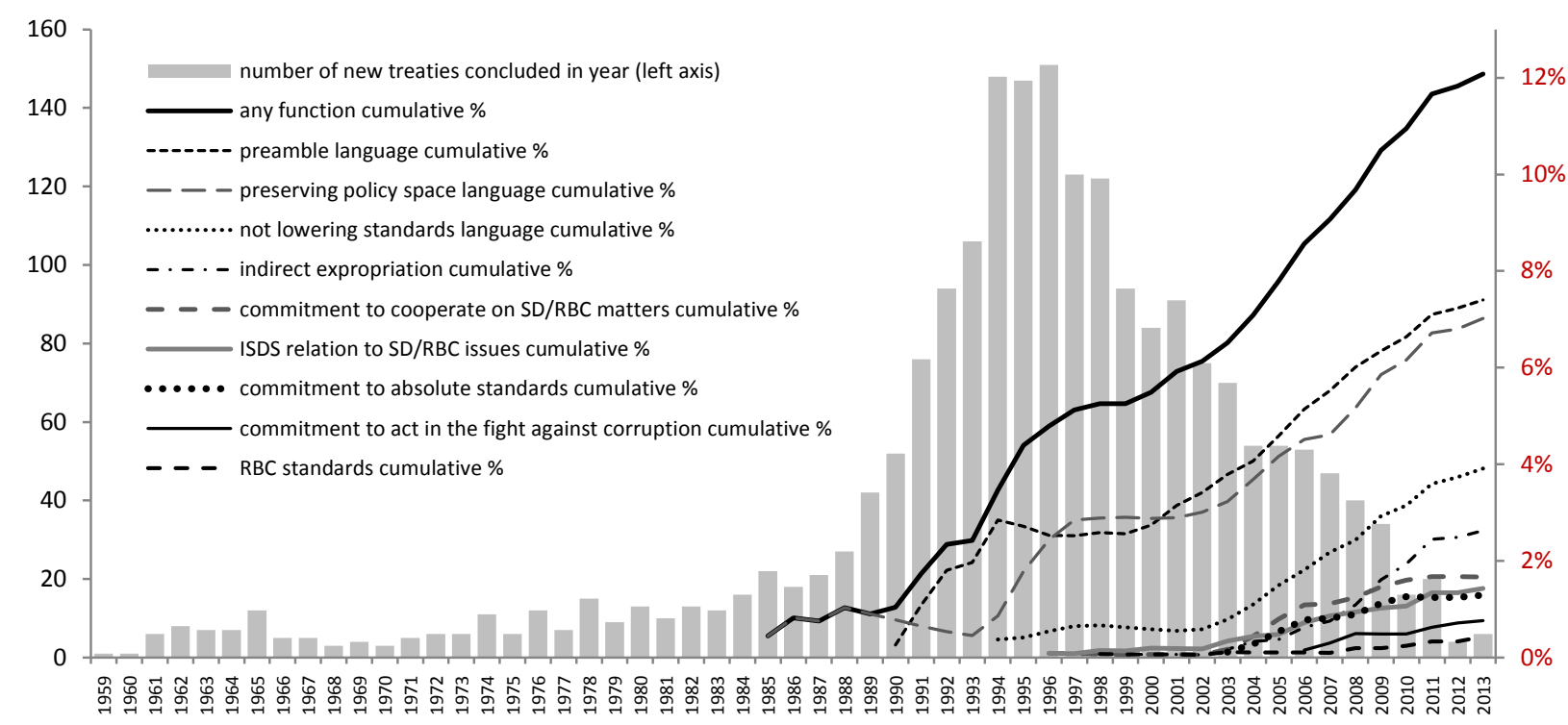
See, for instance, Article 15.14(2) of the Mexico-Bolivia FTA (1994). 
Figure 5 shows the dynamics of the introduction of SD/RBC language having specific functions in treaties signed in individual years. Differentiated by function, it illustrates the frequency of the inclusion of such references in IIAs concluded in a given year. ${ }^{33}$ The graph indicates a clear upward trend in recent years in the inclusion of provisions aimed at preserving policy space and discouraging relaxation of standards, and, at a much lower frequency, of provisions stating the treaty partners' commitments to act in the fight against corruption. The frequency of other categories of SD/RBC treaty language has essentially stagnated in the IIAs concluded in the last decade.

Figure 5. Evolution of SD/RBC references in IIAs concluded in a given year differentiated by the reference's function (three year moving average)

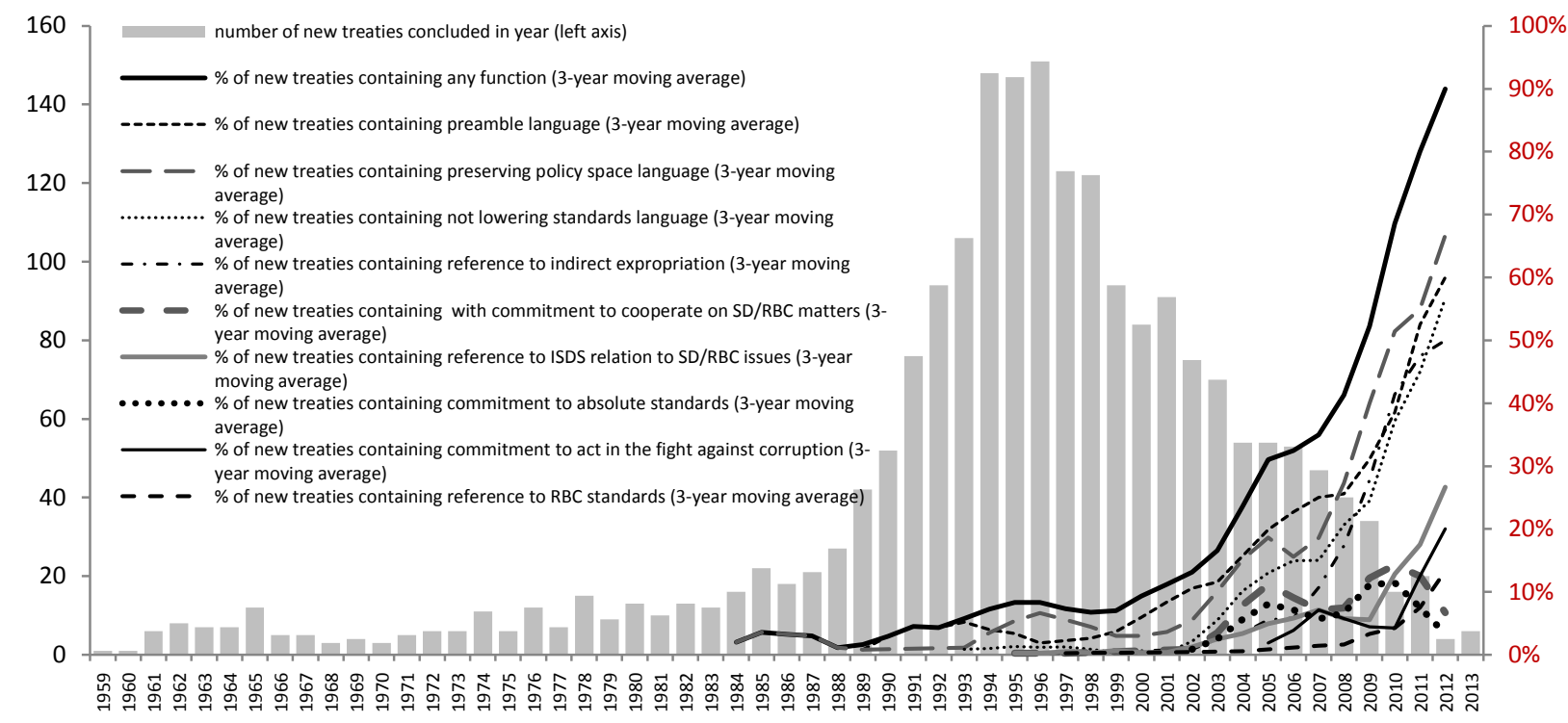

Annex 1 shows which treaties in the sample contain references that fall in these categories, listing only bilateral IIAs that do include $\mathrm{SD} / \mathrm{RBC}$ language. It illustrates, for instance that, while the number of SD/RBC concerns addressed in the treaty sample is limited, the approaches of both individual treaties and countries to this matter varies widely. Some IIAs contain only preamble language referring to $\mathrm{SD} / \mathrm{RBC}$ issues ( 86 of the treaties shown in Annex 1 contain only preamble language). Others contain only one kind of language (47 treaties include language falling only into the preserving policy space category). Still others treaties contain extensive language covering many functions: 19 of the treaties shown in Annex 1 include language covering 5 or more of the policy purposes.

\section{Investment treaty cases and SD/RBC - cross fertilisation or conflict?}
"One of the most [...] urgent problems in international governance is how the different branches and norms of international law interact, and what to do in the event of conflict [...] The main challenge is to marry trade and non-trade rules, or economic and non-economic objectives, at the international level."

\section{Joost Pauwelyn, Conflict of Norms in Public International Law ${ }^{34}$}

\footnotetext{
33 In order to improve readability, the graph shows three year moving averages.

34 Joost Pauwelyn, Conflict of Norms in Public International Law - How WTO Law Relates to other Rules of International Law, Cambridge University Press, 2009, Frontmatter.
} 


\section{A. The general problématique - integrating bodies of law and resolving conflicts}

Investment treaty law coexists with a growing number of other bodies of international law, including many that are of particular relevance for SD/RBC (for example, international instruments in the areas of environmental protection, labour conditions and standards, the fight against corruption and human rights). These different fields of international law are continually evolving and expanding and interacting with one another. At the same time, the disjoint nature of the various bodies of international law and the diverse array of dispute settlement mechanisms associated with them is also increasing.

This profusion of rules and adjudicative bodies tends to expand the potential for conflicts. Such concerns are heightened by the fact that, while international law is becoming increasingly 'dense' (that is, the number of treaties covering various issue areas is expanding rapidly), it has not developed an established hierarchy of norms or adjudicative bodies. Unlike advanced domestic systems, which possess well- established judicial organizations and hierarchies of norms that help to resolve conflicts among rules and competing interpretations, "international law does not presently provide a sufficient set of rules for resolving such conflicts when they do arise". ${ }^{35}$

The interactions between the various bodies of international law - that is how (if at all) the different fields are coordinated in the context of their interpretation and application - are currently being explored in a variety of institutional and academic settings: in the context of international cooperation (in the UN system, at the OECD or in various other cooperation mechanisms set up by international agreements) but also by international adjudicative bodies (such as international courts or arbitral tribunals) and legal scholars.

The starting point of most of these analyses is the Vienna Convention on the Law of Treaties (henceforth, referred to as VCLT) and, in particular, its Section 3, which sets forth the rules of interpretation applicable to all treaties, including IIAs.

The VCLT - and especially its article 31(3)(c) $)^{36}$ - states that all rules of international law where relevant and applicable in the relation between the parties shall be taken into account, together with the context, when interpreting a treaty. 25, 2004, pp. 963-979, p. 968 referring to Joost Pauwelyn, "Bridging Framentation and Unity: International Law as a Universe of Inter-Connected Islands", Michigan Journal of International Law, Vol. 25, 2004, pp.903-929.

In bold in the Box. 


\section{Vienna Convention on the Law of Treaties - rules for interpretation}

\section{SECTION 3. INTERPRETATION OF TREATIES}

Article 31: General rule of interpretation

1. A treaty shall be interpreted in good faith in accordance with the ordinary meaning to be given to the terms of the treaty in their context and in the light of its object and purpose.

2. The context for the purpose of the interpretation of a treaty shall comprise, in addition to the text, including its preamble and annexes:

(a) any agreement relating to the treaty which was made between all the parties in connection with the conclusion of the treaty;

(b) any instrument which was made by one or more parties in connection with the conclusion of the treaty and accepted by the other parties as an instrument related to the treaty.

3. There shall be taken into account, together with the context:

(a) any subsequent agreement between the parties regarding the interpretation of the treaty or the application of its provisions;

(b) any subsequent practice in the application of the treaty which establishes the agreement of the parties regarding its interpretation;

(c) any relevant rules of international law applicable in the relations between the parties.

4. A special meaning shall be given to a term if it is established that the parties so intended.

Article 32: Supplementary means of interpretation

Recourse may be had to supplementary means of interpretation, including the preparatory work of the treaty and the circumstances of its conclusion, in order to confirm the meaning resulting from the application of article 31 , or to determine the meaning when the interpretation according to article 31 :

(a) leaves the meaning ambiguous or obscure; or

(b) leads to a result which is manifestly absurd or unreasonable.

Vienna Convention on the Law of Treaties

The conclusions of the International Law Commission's Study Group on the Fragmentation of International Law indicate that this article, which embodies the principle of "systemic integration", "deals with the case where material sources external to the treaty are relevant in its interpretation" and that "[t]hese may include other treaties, customary rules or general principles of law". ${ }^{38}$ The Study Group on the Fragmentation of International Law was constituted under the aegis of the International Law Commission to study the fragmentation of international law. Its conclusions on the "difficulties arising from the diversification and expansion of international law" ${ }^{\text {"3 }}$, which are aimed at fostering coordination between different fields of international law, provide practical advice for determining the relationships between rules and principles belonging to various bodies of international law and, hence, resolving potential conflicts.

Several scholars have also considered the principle of "systemic integration". With respect to "integration" of international law, McLachlan maintains that "reference to other rules of international law in the course of interpreting a treaty is an everyday, often unconscious, part of the interpretation process. $"{ }^{40} \mathrm{He}$ is of the view that the "systemic integration" of different bodies of international law is

$37 \quad$ Emphasis added.

United Nations, International Law Commission, Conclusions of the Work of the Study Group on the Fragmentation of International Law: Difficulties arising from the Diversification and Expansion of International Law, 2006, para. 18.

United Nations, International Law Commission, Conclusions of the Work of the Study Group on the Fragmentation of International Law: Difficulties arising from the Diversification and Expansion of International Law, 2006.

Campbell McLachlan, "The Principle of Systemic Integration and Article 31(3)(c) of the Vienna Convention”, International and Comparative Law Quarterly, Vol. 54, Issue 2, April 2005, p. 280. 
an ongoing, gradual process. In a similar vein, Philippe Sands refers to the growing tendency towards "cross-fertilisation" across bodies of international law. ${ }^{41}$ Under this view adjudicative bodies in international law increasingly seek to apply international law (including investment treaty law) in its general context - that is, interpreting treaties while also integrating, where relevant and applicable, other components of international law (both customary and conventional) and of domestic law.

According to these perspectives, treaty interpreters should look for guidance in other rules and principles of international law for all the questions that are not expressly resolved by the treaty interpreted. This would seem to imply that investment arbitration tribunals should interpret and apply IIAs in their general context, that is taking into customary international law, general principles of law and consideration rules and principles from other fields of international law, including bodies of law relating to $\mathrm{SD} / \mathrm{RBC}$, where relevant and applicable.

Under this view, potential influences between investment treaty law and other fields of international law relevant for SD/RBC law run in both directions. Referring to other bodies of international law relevant for SD/RBC could, for instance, be relevant for interpreting States' compliance with their investment treaty obligations in some cases. Conversely, investment treaty law could also provide guidance on how SD/RBC policies should be designed and implemented in order to comply with the States' investment treaty obligations.

Sections 3.B. and 3.C. aim to shed preliminary empirical light on these interactions and, more specifically, on whether issues and international agreements of particular relevance for SD/RBC are referred to in investment arbitration cases:

- Section 3.B looks at whether arbitration panels refer to broader issues than investment protection;

- Section 3.C. examines the related question of whether arbitral tribunals mention other international agreements in the areas of environmental protection, labour conditions and standards, anti-corruption and human rights.

\section{B. Reference to $S D / R B C$ issues in investment arbitration cases}

One important interaction of investment protection and SD/RBC occurs when the two sets of issues intersect in the context of ISDS. The question raised in this context is whether arbitration panels confine their reasoning to the "four corners of the treaty" 42 - that is, taking into account only the commitments explicitly undertaken by the State parties in the IIA itself - or do they also refer to broader issues (such as domestic and international law relevant for SD/RBC)?

This section reports on the results of a survey of investment arbitration cases that mention SD/RBC issues. More specifically, a sample of 1113 documents contained in a subscription database - the "Investor State Law Guide" -- and issued from treaty-based investment cases ${ }^{43}$ was searched for

$41 \quad$ Philippe Sands, "Treaty, Custom and the Cross-fertilisation of International Law", Yale Human Rights and Development Law Journal, Vol. I, November 1999, pp. 85-106.

The term «four corners of the treaty » can be found in Campbell McLachlan, "The Principle of Systemic Integration and Article 31(3)(c) of the Vienna Convention", International and Comparative Law Quarterly, Vol. 54, Issue 2, April 2005, p. 280. decisions on jurisdiction, awards on merits, and separate opinions rendered by arbitrator(s), as well as 
the following SD/RBC-sensitive key words: "environment", "corruption", "bribery", "labour conditions", "labour standards", "labour law", and "human rights".

The purpose of this key word search is to generate preliminary statistical information on what might be termed the 'cross fertilisation' or 'integration' principles described above. The results suggest that arbitrators might, in some cases, refer to SD/RBC issues alongside their consideration of a State's compliance with the IIAs' commitments on investment protection.

Specifically, 287 of the 1113 decisions surveyed mention at least one of these issues at least once - that is, $26 \%$ of the documents deal in some way with these SD/RBC-sensitive issues. The breakdown of references is as follows:

- The term "environment" occurs in 165 decisions;

- The term "human rights" is found in 131 documents;

- "Corruption" is referred to in 81 decisions, and "bribery" in 29 documents;

- References to "labour conditions", "labour standards" or "labour law" can be found in 2 decisions. A broader key word search on the term "labo(u)r" produced 131 results.

In summary, the survey of treaty-based investment arbitration cases shows that $26 \%$ of the decisions rendered in this framework refer to issues other than the investment protection commitments contained within the "four corners of the treaty". At times, these references involve lengthy discussion of issues such as corruption, protection of the environment or of human rights. However, the present survey is merely statistical and does not explore arbitrators' reasoning. As such, it does not permit inferences as to whether the treatment of these issues involves persuasive legal reasoning and whether the $74 \%$ of cases that did not deal with such issues should have. It nevertheless provides a starting point to affirm that investment arbitration cases sometimes involve broader considerations than investment protection.

\section{3. $C$. References to international agreements relevant for $S D / R B C$ in investment arbitration cases}

The preceding section shows that some arbitration panels refer to issues of particular interest to $\mathrm{SD} / \mathrm{RBC}$ when adjudicating treaty-based investor-state disputes. This section explores a more specific, but related question: whether arbitration panels refer to international agreements relevant for $\mathrm{SD} / \mathrm{RBC}$ (e.g. agreements dealing with environmental protection, labour conditions and standards, anti-corruption and human rights) when deciding arbitration cases.

The present section explores this question empirically. The same sample of 1113 documents contained in the "Investor State Law Guide" database was searched for references to major

decisions of annulment committees. For convenience, they are referred to hereafter as "decisions" or "documents".

A summary examination of the 20 first results produced by the general search on the key term "labo(u)r" shows that the cases referring to this term involve issues such as non-payment of workers in the context of bankruptcy and labour market flexibility or labour policy in the context of government responses to economic crises. 
multilateral environmental agreements, anti-corruption conventions, human rights agreements and ILO instruments. ${ }^{46}$ The survey limits itself to quantifying the frequency of such references in the sample of documents issued from treaty-based investment arbitration cases, without examining the legal reasoning underpinning these references.

The survey findings support the view that there is some interaction between ISDS and international agreements relevant for SD/RBC. A total of 28 agreements were cited in the sample of 1113 documents. Interestingly, none of the decisions surveyed refer to ILO instruments on labour conditions and standards. ${ }^{47}$

Table 3 provides the list of these international agreements and the number of decisions in which each is referenced. Annex 3 provides detailed quotes of these references.

Table 3. Environmental, Human Rights and Anti-corruption Agreements cited in investment arbitration cases

\begin{tabular}{|c|c|}
\hline Name of International Agreement & $\begin{array}{c}\text { No. of } \\
\text { documents citing } \\
\text { the agreement at } \\
\text { least once }\end{array}$ \\
\hline \multicolumn{2}{|l|}{ International Environmental Agreements } \\
\hline $\begin{array}{l}\text { Aarhus Protocol on Persistent Organic Pollutants to the UNECE Convention on Long-Range Trans-boundary Air } \\
\text { Pollution of } 1979 \text { (1998) }\end{array}$ & 1 \\
\hline $\begin{array}{l}\text { Basel Convention on the Control of Trans-boundary Movements of Hazardous Wastes and their Disposal } \\
\text { (1989) }\end{array}$ & 2 \\
\hline Espoo Convention on Environmental Impact Assessment in a Trans-boundary Context (1991) & 1 \\
\hline North American Agreement on Environmental Cooperation (1993) & 2 \\
\hline $\begin{array}{l}\text { OSPAR Convention - Convention for the Protection of the Marine Environment of the North-East Atlantic } \\
\text { (1992) }\end{array}$ & 4 \\
\hline $\begin{array}{l}\text { Resolution adopted by the General Assembly: } 1803 \text { (XVII). Permanent sovereignty over natural resources } \\
(1962)\end{array}$ & 2 \\
\hline Rio Declaration on Environment and Development (1992) & 3 \\
\hline Stockholm Convention on Persistent Organic Pollutants (2001) & 1 \\
\hline Stockholm Declaration on the Human Environment (1972) & 1 \\
\hline UNESCO Convention concerning the Protection of the World Cultural Property and Natural Heritage (1972) & 1 \\
\hline United Nations Convention on the Law of the Sea (1982) & 3 \\
\hline United Nations Framework Convention on Climate Change (1992) & 1 \\
\hline United States - Mexico Treaty Relating to the Utilization of Water (1944) & 1 \\
\hline International Human Rights Agreements & \\
\hline
\end{tabular}

46 A full list of the international agreements relevant for SD/RBC that were searched for is provided in Annex 4.

47 The Indigenous and Tribal Peoples Convention No. 169 (1989) adopted under the aegis of the International Labour Organisation is cited but is categorised, for the purposes of this survey, as a human rights instrument.

The documents include decisions on petition for intervention as amicus curiae, decisions on jurisdiction, awards on merits, and separate opinions rendered by arbitrator(s), as well as decisions of annulment committees. If an agreement is cited several times in the same case but in different dispute documents, the total number of different documents is counted. If several references to the same international instrument appear in the same dispute document, it is counted only once. 


\begin{tabular}{|c|c|}
\hline Name of International Agreement & $\begin{array}{c}\text { No. of } \\
\text { documents citing } \\
\text { the agreement at } \\
\text { least once }\end{array}$ \\
\hline Charter of Fundamental Rights of the European Union (2000) & 1 \\
\hline Convention on the Prevention and Punishment of the Crime of Genocide (1948) & 7 \\
\hline European Convention on Human Rights (1950) & 27 \\
\hline Indigenous and Tribal Peoples Convention No. 169 (1989) different & 1 \\
\hline Inter-American Convention on Human Rights (1969) & 2 \\
\hline International Convention on the Elimination of All Forms of Racial Discrimination (1965) & 8 \\
\hline International Covenant on Civil and Political Rights (1966) & 5 \\
\hline International Covenant on Economic, Social and Cultural Rights (1966) & 1 \\
\hline $\begin{array}{l}\text { Resolution adopted by the General Assembly: } 61 / 295 \text { United Nations Declaration on the Rights of Indigenous } \\
\text { Peoples (2007) }\end{array}$ & 1 \\
\hline Universal Declaration of Human Rights (1948) & 3 \\
\hline \multicolumn{2}{|l|}{ International Anti-Corruption Agreements } \\
\hline African Union Convention on Preventing and Combating Corruption (2003) & 1 \\
\hline Council of Europe Civil and Criminal Law Conventions on Corruption (1999) & 1 \\
\hline $\begin{array}{l}\text { OECD Convention on Combating Bribery of Foreign Public Officials in International Business Transactions } \\
(1997)\end{array}$ & 3 \\
\hline United Nations Convention Against Corruption (2003) & 1 \\
\hline \multicolumn{2}{|l|}{ Miscellaneous International Agreements } \\
\hline Jay Treaty (1794) & 2 \\
\hline
\end{tabular}

\section{Conclusions and caveats}

The present paper provides evidence that investment treaty law does interact with other bodies of international law of particular relevance to $\mathrm{SD} / \mathrm{RBC}$. The vast majority of recently concluded IIAs refer to at least one of the four SD/RBC issues considered in the survey (environmental protection, labour conditions and standards, anti-corruption and human rights). In addition, some treaty-based investment arbitration cases also refer to these four issues, as well as to international agreements of relevance for $\mathrm{SD} / \mathrm{RBC}$.

These findings, however, are subject to certain caveats and point to outstanding challenges for investment treaty lawmakers:

- Updating the treaty stock. Although nearly all recently concluded IIAs contain various types of language referring to SD/RBC issues, these treaties are a distinct minority in the entire sample. Indeed, new thinking and innovations in investment treaty commitments can only with difficulty be reflected across more than 2000 IIAs of all ages as updating treaties can be costly and time consuming. The OECD-hosted "Freedom of Investment" Roundtable examines the options available for governments wishing to adapt the content of their IIAs to changing needs and circumstances, while also preserving the benefits of stability and predictability.

- Making sure that ISDS mechanisms and broader treaty provisions are well designed. The substantive and procedural provisions contained in IIAs form a single and inseparable whole. The ISDS mechanisms set up by the treaties' procedural provisions are the channel through which States' (often broadly framed) substantive investment treaty commitments are enforced. Yet, earlier OECD treaty surveys have shown that ISDS mechanisms tend to be 
"lightly regulated" in the majority of IIAs and that silence on most procedural questions is the dominant treaty practice for dispute settlement ${ }^{49}$. Other OECD studies also indicate that advanced systems of national law handle similar legal questions in ways that are very different from the way they are generally handled under investment treaty law ${ }^{50}$. Governments will want to be mindful of the need to craft IIAs that not only advance their objectives in relation to $\mathrm{SD} / \mathrm{RBC}$ but that also include ISDS provisions aimed at ensuring that such concerns are taken into account by those in charge of interpreting and applying the treaties.

See David Gaukrodger and Kathryn Gordon "Investor State Dispute Settlement: A Scoping Paper for the Investment Policy Community", OECD Working Paper on International Investment, No. 2012/3, OECD Publishing, p. 64.

See, for example, David Gaukrodger, "Investment Treaties as Corporate Law: Shareholder Claims and Issues of Consistency - A Preliminary Framework for Analysis", OECD Working Paper on International Investment, No. 2013/3, OECD Publishing, pp 15-20. 


\section{ANNEX 1. INTERNATIONAL INVESTMENT AGREEMENTS WITH SD/RBC LANGUAGE - DETAILED OVERVIEW}

This annex lists the IIAs that contain SD/RBC language. The list includes only treaties that contain at least one reference to SD/RBC concerns. All treaties that a participant in the Freedom of Investment Roundtables has concluded are listed; that leads to duplicate mentioning of a certain number of treaties in the table. Treaties are sorted by alphabetical order of the treaty partner, and, in second order, by the year of signature. Shading of rows groups treaties of the same country are meant to enhance readability.

\begin{tabular}{|c|c|c|c|c|c|c|c|c|c|c|c|c|c|}
\hline \multirow[t]{2}{*}{ TREATY (YEAR OF SIGNATURE) } & \multicolumn{4}{|c|}{ REFERENCE TO } & \multicolumn{9}{|c|}{ FUNCTION OF THE REFERENCE } \\
\hline & 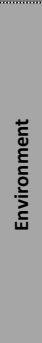 & Jٍ & 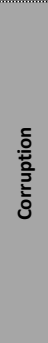 & 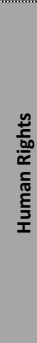 & 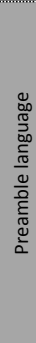 & 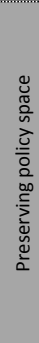 & 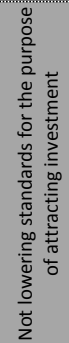 & 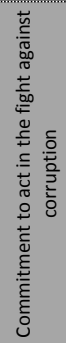 & 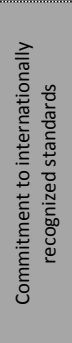 & 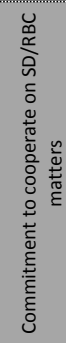 & 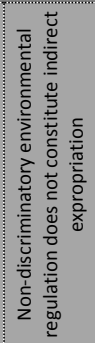 & 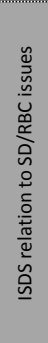 & 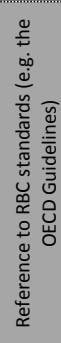 \\
\hline Argentina-New Zealand BIT (1999) & - & & & & & • & & & & & & & \\
\hline Argentina-United States BIT (1991) & & . & & & • & & & & & & & & \\
\hline Australia-Chile FTA (2008) & - & & & & • & - & & & & & - & & \\
\hline $\begin{array}{l}\text { Australia-New Zealand (ANZCERTA Investment } \\
\text { Protocol) (2011) }\end{array}$ & $\cdot$ & & & & $\cdot$ & $\cdot$ & & & & & • & & \\
\hline Australia-Singapore FTA (2004) & - & & & & & - & & & & & & & \\
\hline Australia-Thailand FTA (2004) & - & & & & & - & & & & & & & \\
\hline Australia-United States FTA (2004) & - & - & & & - & - & - & & - & - & - & & \\
\hline Austria-Armenia BIT (2001) & & - & & & - & & & & & & & & \\
\hline Austria-Azerbaijan BIT (2000) & & - & & & - & & & & & & & & \\
\hline Austria-Bangladesh BIT (2000) & & - & & & - & & & & & & & & \\
\hline Austria-Belize BIT (2001) & & • & & & • & & & & & & & & \\
\hline Austria-Bosnia and Herzegovina BIT (2000) & & - & & & - & & & & & & & & \\
\hline Austria-Cuba BIT (2000) & & - & & & - & & & & & & & & \\
\hline Austria-FYROM BIT (2001) & & • & & & • & & & & & & & & \\
\hline Austria-Georgia BIT (2001) & & - & & & - & & & & & & & & \\
\hline Austria-Guatemala BIT (2006) & & • & & & - & & & & & & & & \\
\hline Austria-Jordan BIT (2001) & & • & & & - & & & & & & & & \\
\hline Austria-Kazakhstan BIT (2010) & - & - & - & - & - & & - & & & & & & \\
\hline Austria-Kosovo BIT (2010) & - & • & - & - & - & - & - & & & & - & & \\
\hline Austria-Kuwait BIT (1996) & - & & & & & - & & & & & & & \\
\hline Austria-Malta BIT (2002) & & - & & - & - & & & & & & & & \\
\hline Austria-Mexico BIT (1998) & & & & & & & & & & & & & - \\
\hline Austria-Namibia BIT (2003) & & $\cdot$ & & & $\cdot$ & & & & & & & & \\
\hline Austria-Slovenia BIT (2001) & & - & & & - & & & & & & & & \\
\hline Austria-Tajikistan BIT (2011) & - & • & • & - & • & • & - & & & & - & & - \\
\hline Austria-Uzbekistan BIT (2000) & & & - & & & & & & & & & - & \\
\hline
\end{tabular}




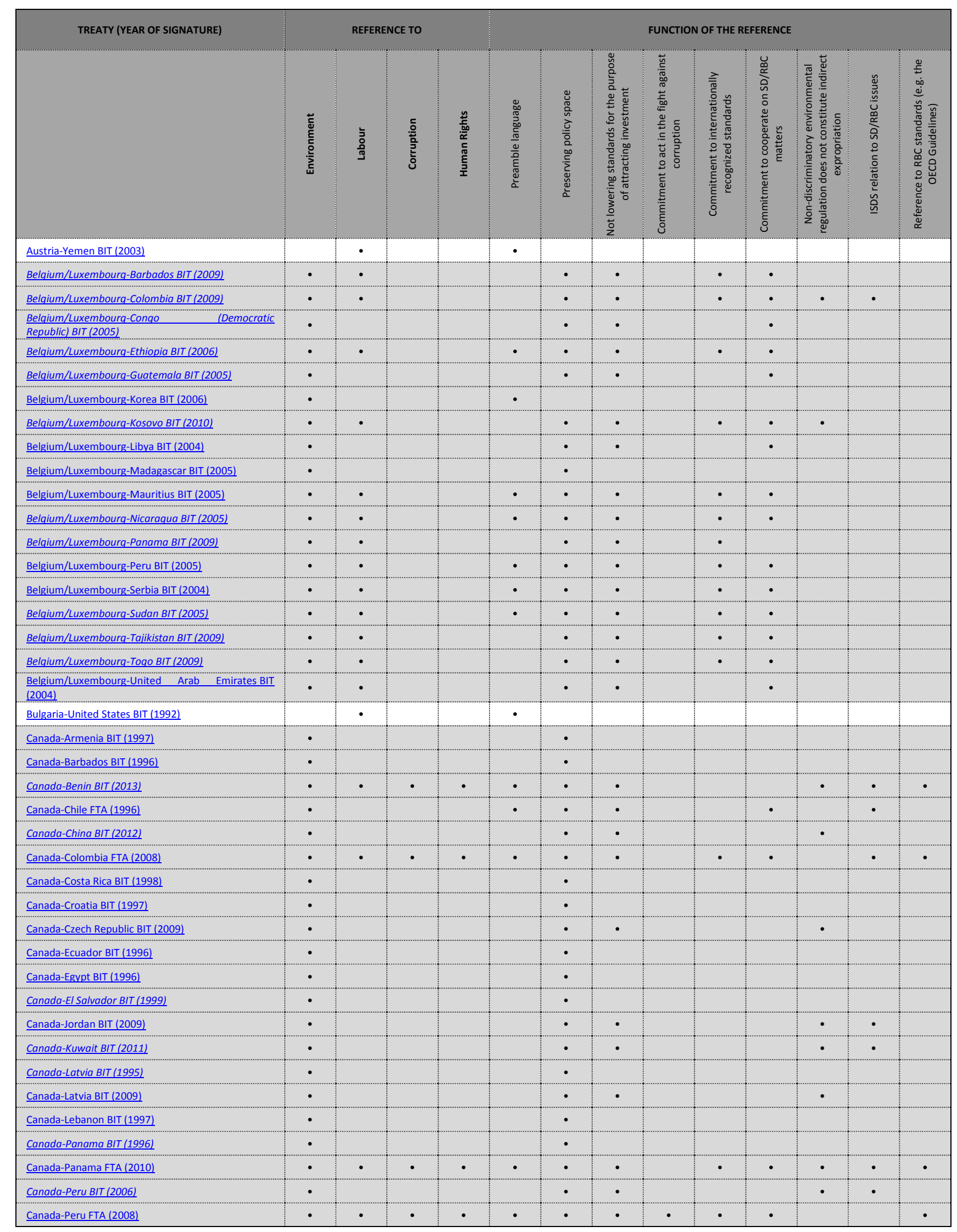




\begin{tabular}{|c|c|c|c|c|c|c|c|c|c|c|c|c|c|}
\hline \multirow[t]{2}{*}{ TREATY (YEAR OF SIINATURE) } & \multicolumn{4}{|c|}{ REFERENCE TO } & \multicolumn{9}{|c|}{ FUNCTION OF THE REFERENCE } \\
\hline & 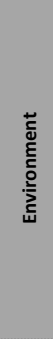 & 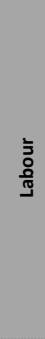 & 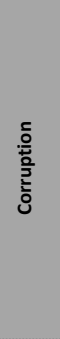 & 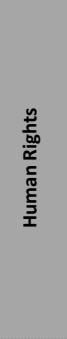 & 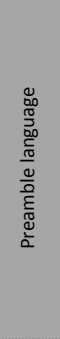 & 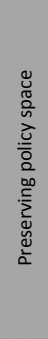 & 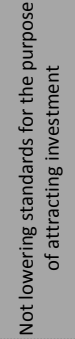 & 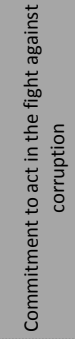 & 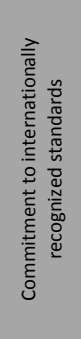 & 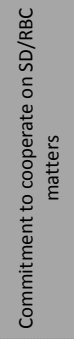 & 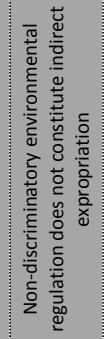 & 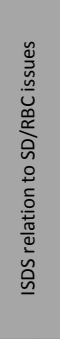 & 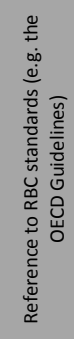 \\
\hline Canada-Philippines BIT (1995) & - & & & & & - & & & & & & & \\
\hline Canada-Romania BIT (1996) & - & & & & & $\cdot$ & - & & & & - & & \\
\hline Canada-Romania BIT (2009) & - & & & & & - & - & & & & - & & \\
\hline Canada-Slovakia BIT (2010) & - & & & & & - & - & & & & - & & \\
\hline Canada-South Africa BIT (1995) & $\cdot$ & & & & & $\cdot$ & 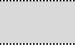 & & & & 3 & & \\
\hline Canada-Tanzania BIT (2013) & $\cdot$ & & & & & $\cdot$ & $\cdot$ & & & & $\cdot$ & & \\
\hline Canada-Thailand BIT (1997) & - & & & & & - & & & & & & & \\
\hline Canada-Trinidad and Tobago BIT (1995) & . & & & & & - & & & & & & & \\
\hline Canada-Ukraine BIT (1994) & - & & & & & - & & & & & & & \\
\hline Canada-Uruguay BIT (1997) & - & & & & & - & - & & & & & & \\
\hline Canada-Venezuela BIT (1996) & - & & & & & - & & & & & & & \\
\hline Chile-Australia FTA (2008) & $\cdot$ & & & & - & $\cdot$ & 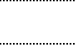 & & & & - & & \\
\hline Chile-Canada FTA (1996) & - & & & & - & • & - & & & - & & • & \\
\hline Chile-Colombia FTA (2006) & - & - & - & & - & • & - & $\cdot$ & - & - & & • & \\
\hline Chile-Japan EPA (2007) & - & & & & - & & - & & & & & - & \\
\hline Chile-Korea FTA (2003) & $\cdot$ & & & & - & - & - & & & & . & - & \\
\hline Chile-Mexico FTA (1998) & • & • & & & - & • & - & & & 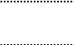 & & • & \\
\hline Chile-Peru FTA (2006) & - & 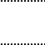 & & & - & - & 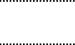 & & & - & - & • & \\
\hline Chile-United States FTA (2003) & $\cdot$ & $\cdot$ & & & $\cdot$ & $\cdot$ & $\cdot$ & & $\cdot$ & $\cdot$ & $\cdot$ & $\cdot$ & \\
\hline China-Canada BIT (2012) & $\cdot$ & & & & 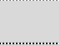 & $\cdot$ & - & & & & - & & \\
\hline China-Guyana BIT (2003) & - & & & & - & & & & & & & & \\
\hline China-New Zealand BIT (1988) & $\cdot$ & & & & & - & & & & 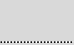 & & & \\
\hline China-New Zealand FTA (2008) & - & - & & & $\cdot$ & - & & & & - & - & & \\
\hline China-Peru FTA (2009) & - & - & & & - & & & & & - & & & \\
\hline China-singapore BIT (1985) & - & & & & & - & & & & & & & \\
\hline China-Sri Lanka BIT (1986) & - & & & & & - & & & & & & & \\
\hline Colombia-Belgium/Luxembourg BIT (2009) & $\cdot$ & - & & & & - & - & & - & - & - & $\cdot$ & \\
\hline Colombia-Canada FTA (2008) & $\cdot$ & - & • & - & - & . & - & & - & - & & $\cdot$ & $\cdot$ \\
\hline Colombia-Chile FTA (2006) & - & - & - & & - & - & - & - & - & - & & - & \\
\hline Colombia-India BIT (2009) & - & & & & & - & & & & & - & & \\
\hline Colombia-Japan BIT (2011) & $\cdot$ & $\cdot$ & $\cdot$ & & $\cdot$ & $\cdot$ & $\cdot$ & $\cdot$ & & & & $\cdot$ & \\
\hline Colombia-Korea FTA (2013) & $\cdot$ & & $\cdot$ & & - & $\cdot$ & & & $\cdot$ & & - & $\cdot$ & \\
\hline Colombia-Mexico FTA (1994) & $\cdot$ & - & & & $\cdot$ & & $\cdot$ & & & & & & \\
\hline Colombia-Peru BIT (2007) & - & & & & & - & - & & & & - & - & \\
\hline Colombia-United Kingdom BIT (2010) & - & & & & & - & & & & & - & & \\
\hline Costa Rica-Canada BIT (1998) & • & & & & & - & & & & & & & \\
\hline Costa Rica-Mexico FTA (1994) & - & - & & & - & - & - & & & & & & \\
\hline Costa Rica-Peru FTA (2011) & - & & & & & - & - & & & & - & - & \\
\hline Costa Rica-Singapore FTA (2010) & - & - & & & - & - & & & - & - & - & & \\
\hline Czech Republic-Azerbaijan BIT (2011) & $\cdot$ & & & & $\cdot$ & & & & & & & & \\
\hline Czech Republic-Canada BIT (2009) & - & & & & & - & - & & & & • & & \\
\hline Crech Republic-India BIT (1996) & - & & & & & • & & & & & & & \\
\hline
\end{tabular}




\begin{tabular}{|c|c|c|c|c|c|c|c|c|c|c|c|c|c|}
\hline \multirow[t]{2}{*}{ TREATY (YEAR OF SIINATURE) } & \multicolumn{4}{|c|}{ REFERENCE TO } & \multicolumn{9}{|c|}{ FUNCTION OF THE REFERENCE } \\
\hline & 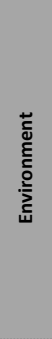 & $\begin{array}{l}\text { 言 } \\
\frac{\mathrm{g}}{\mathrm{g}}\end{array}$ & 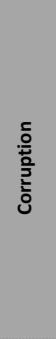 & 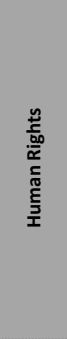 & 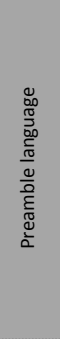 & 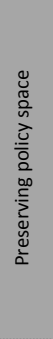 & 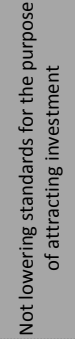 & 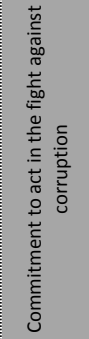 & 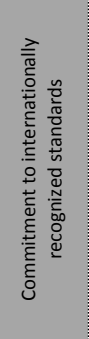 & 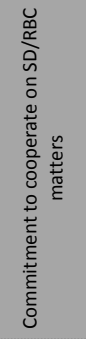 & 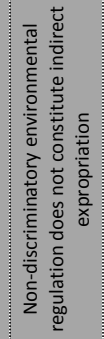 & 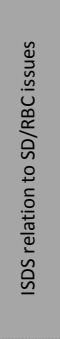 & 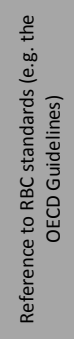 \\
\hline Crech Republic-Mauritius BIT (1999) & - & & & & & - & & & & & & & \\
\hline Czech Republic-Singapore BIT (1995) & $\cdot$ & & & & & $\cdot$ & & & & & & & \\
\hline Crech Republic-United States BIT (1991) & & - & & & • & & & & & & & & \\
\hline Egypt-Canada BIT (1996) & $\cdot$ & & & & 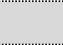 & - & & & & & & & \\
\hline Egypt-Switzerland BIT (2010) & $\cdot$ & & & & $\cdot$ & & & & & & & & \\
\hline Estonia-Azerbaijan BIT (2010) & $\cdot$ & & & & $\cdot$ & & & & & & & & \\
\hline Estonia-United-States BIT (1994) & & - & & & - & & & & & & & & \\
\hline Finland-Algeria BIT (2005) & - & • & & & - & & & & & & & & \\
\hline Finland-Armenia BIT (2004) & - & & & & - & & & & & & & & \\
\hline Finland-Belarus BIT (2006) & - & - & & & - & & & & & & & & \\
\hline Finland-Bosnia and Herzegovina BIT (2000) & - & .... & & & . & & & & & & & & \\
\hline Finland-EI Salvador BIT (2002) & - & & & & - & - & & & & & & & \\
\hline Finland-Ethiopia BIT (2006) & - & - & & & - & & & & & & & & \\
\hline Finland-FYROM BIT (2001) & - & & & & - & & & & & & & & \\
\hline Finland-Georgia BIT (2006) & - & & & & - & & & & & & & & \\
\hline Finland-Guatemala BIT (2005) & - & - & & & - & & & & & & & & \\
\hline Finland-Jordan BIT (2006) & • & & & & - & & & & & & & & \\
\hline Finland-Kazakhstan BIT (2007) & - & 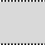 & & & - & & & & & & & & \\
\hline Finland-Krrgyzstan BIT (2003) & $\cdot$ & $\cdot$ & & & $\cdot$ & & & & & & & & \\
\hline Finland-Mauritius BIT (2007) & $\cdot$ & & & & $\cdot$ & & & & & & & & \\
\hline Finland-Mongolia BIT (2007) & - & & & & - & & & & & & & & \\
\hline Finland-Montenegro BIT (2008) & . & - & & & - & & & & & & & & \\
\hline Finland-Morambique BIT (2004) & - & & & & $\cdot$ & & & & & & & & \\
\hline Finland-Namibia BIT (2002) & - & & & & - & - & & & & & & & \\
\hline Finland-Nepal BIT (2009) & - & & & & - & & & & & & & & \\
\hline Finland-Nicaragua BIT (2003) & - & - & & & $\cdot$ & & & & & & & & \\
\hline Finland-Nigeria BIT (2005) & . & - & & & $\cdot$ & & & & & & & & \\
\hline Finland-Panama BIT (2009) & $\cdot$ & $\cdot$ & & & . & - & & & & & & & \\
\hline Finland-Serbia BIT (2005) & - & - & & & - & & & & & & & & \\
\hline Finland-Tanzania BIT (2001) & - & . & & & - & & & & & & & & \\
\hline Finland-Ukraine BIT (2004) & - & & & & $\cdot$ & & & & & & & & \\
\hline Finland-Vietnam BIT (2008) & - & $\cdot$ & & & - & & & & & & & & \\
\hline Finland-Zambia BIT (2005) & - & - & & & $\cdot$ & $\cdot$ & & & & & & & \\
\hline France-India BIT (1997) & - & & & & & - & & & & & & & \\
\hline Germany-India BIT (1995) & - & & & & & - & & & & & & & \\
\hline Germany-Trinidad and Tobago BIT (2006) & - & & & & - & & & & & & & & \\
\hline Hungary-Russian Federation BIT (1995) & - & & & & & - & & & & & & & \\
\hline Iceland-India BIT (2007) & - & & & & & - & & & & & - & & \\
\hline India-Armenia BIT (2003) & - & & & & & - & & & & & - & & \\
\hline India-Bahrain BIT (2004) & $\cdot$ & & & & & $\cdot$ & & & & & - & & \\
\hline India-Bosnia and Herzegovina BIT (2006) & - & & & & & - & & & & & & & \\
\hline India-Brunei Darussalam BIT (2008) & - & & & & & - & & & & & - & & \\
\hline
\end{tabular}




\begin{tabular}{|c|c|c|c|c|c|c|c|c|c|c|c|c|c|}
\hline \multirow[t]{2}{*}{ TREATY (YEAR OF SIGNATURE) } & \multicolumn{4}{|c|}{ REFERENCE TO } & \multicolumn{9}{|c|}{ FUNCTION OF THE REFERENCE } \\
\hline & 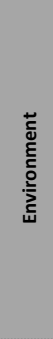 & 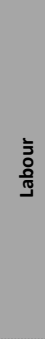 & 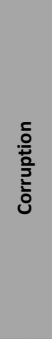 & 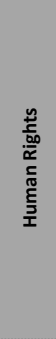 & 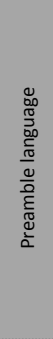 & 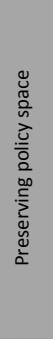 & 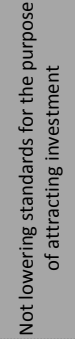 & 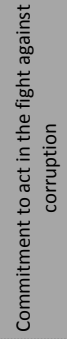 & 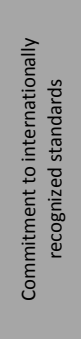 & 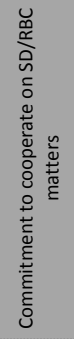 & 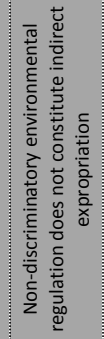 & 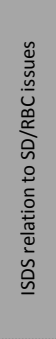 & 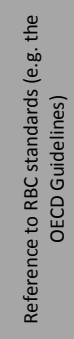 \\
\hline India-Colombia BIT (2009) & - & & & & & - & & & & & - & & \\
\hline India-Czech Republic BIT (1996) & - & & & & & $\cdot$ & & & & & & & \\
\hline India-France BIT (1997) & - & & & & & • & & & & & & & \\
\hline India-Germany BIT (1995) & - & & & & & $\cdot$ & & & & & & & \\
\hline India-Iceland BIT (2007) & $\cdot$ & & & & & $\cdot$ & & & & & - & & \\
\hline India-Italy BIT (1995) & $\cdot$ & & & & & $\cdot$ & & & & & & & \\
\hline India-Japan EPA (2011) & - & & - & & - & & - & - & & - & & & \\
\hline India-Jordan BIT (2006) & $\cdot$ & & & & & $\cdot$ & & & & & - & & \\
\hline India-Korea BIT (1996) & - & & & & & - & & & & & & & \\
\hline India-Korea CEPA (2009) & - & & & & - & - & - & & & & - & & \\
\hline India-Kuwait BIT (2001) & - & & & & & - & & & & & & & \\
\hline India-Latvia BIT (2010) & $\cdot$ & & & & & $\cdot$ & & & & & - & & \\
\hline India-Lithuania BIT (2011) & - & & & & & $\cdot$ & & & & & - & & \\
\hline India-Mauritius BIT (1998) & - & & & & & - & & & & & & & \\
\hline India-Mozambique BIT (2009) & - & & & & & - & & & & & - & & \\
\hline India-Nepal BIT (2011) & - & & & & & - & & & & & - & & \\
\hline India-Senegal BIT (2008) & • & & & & & - & & & & & • & & \\
\hline India-Slovenia BIT (2011) & - & & & & & - & & & & & - & & \\
\hline India-Syria BIT (2008) & $\cdot$ & & & & & $\cdot$ & - & . & & & $\cdot$ & & \\
\hline Indonesia-Japan EPA (2007) & $\cdot$ & & $\cdot$ & & & & - & $\cdot$ & & & & & \\
\hline Indonesia-Mauritius BIT (1997) & - & & & & & $\cdot$ & & & & & & & \\
\hline Italy-India BIT (1995) & $\cdot$ & & & & & $\cdot$ & 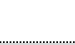 & & & & & & \\
\hline Japan-Brunei Darussalam EPA (2007) & - & & & & - & & - & 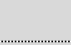 & & & & & \\
\hline Japan-Cambodia BIT (2007) & - & & - & & - & & - & - & & & & & \\
\hline Japan-Chile EPA (2007) & - & & & & - & & - & . & & & & - & \\
\hline Japan-Colombia BIT (2011) & - & - & - & & - & $\cdot$ & - & - & & & & $\cdot$ & \\
\hline Japan-India EPA (2011) & . & & $\cdot$ & & - & & - & - & & - & & & \\
\hline Japan-Indonesia EPA (2007) & - & & . & & . & & - & - & & & & & \\
\hline Japan-Iraq BIT (2012) & • & - & • & & • & & - & - & & & & & \\
\hline Japan-Korea BIT (2002) & - & & & & - & - & - & 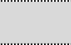 & & & & & \\
\hline Japan-Kuwait BIT (2012) & $\cdot$ & $\cdot$ & $\cdot$ & & $\cdot$ & $\cdot$ & - & $\cdot$ & & & & & \\
\hline Japan-Lao PDR BIT (2008) & $\cdot$ & & - & & $\cdot$ & $\cdot$ & - & $\cdot$ & & & & & \\
\hline Japan-Malaysia EPA (2005) & $\cdot$ & & & & & & - & & & & & & \\
\hline Japan-Mexico EPA (2004) & - & & & & & - & - & & & & & - & \\
\hline Japan-Mozambique BIT (2013) & - & - & - & & - & - & - & - & & & & & \\
\hline Japan-Papua New Guinea BIT (2011) & - & - & - & & - & & - & - & & & & & \\
\hline Japan-Peru BIT (2008) & - & - & - & & $\cdot$ & - & - & - & & & & & \\
\hline Japan-Philippines EPA (2006) & • & - & - & & & - & - & - & - & - & & & \\
\hline Japan-Saudi Arabia BIT (2013) & - & & & & - & & - & & & & & & \\
\hline Japan-Singapore EPA (2002) & - & & & & & - & & & & & & & \\
\hline Japan-Switzerland EPA (2009) & • & - & & • & • & & - & & & & & & \\
\hline Japan-Thailand EPA (2007) & - & & - & & & & - & - & & & & & \\
\hline
\end{tabular}




\begin{tabular}{|c|c|c|c|c|c|c|c|c|c|c|c|c|c|}
\hline \multirow[t]{2}{*}{ TREATY (YEAR OF SIGNATURE) } & \multicolumn{4}{|c|}{ REFERENCE TO } & \multicolumn{9}{|c|}{ FUNCTION OF THE REFERENCE } \\
\hline & 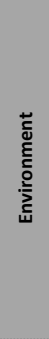 & $\begin{array}{l}\text { 言 } \\
\text { gog }\end{array}$ & 亭 & 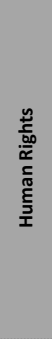 & 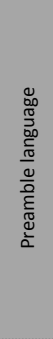 & 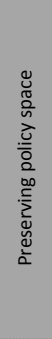 & 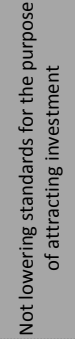 & 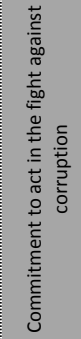 & 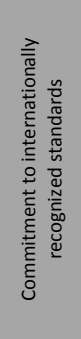 & 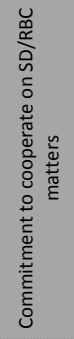 & 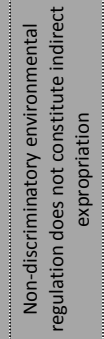 & 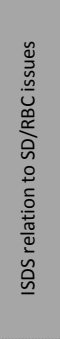 & 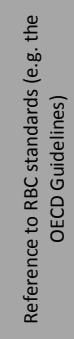 \\
\hline Japan-Uzbekistan BIT (2008) & - & - & - & & - & - & - & - & & & 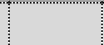 & & \\
\hline Japan-Vietnam BIT (2003) & - & & & & - & - & - & & & & & & \\
\hline Jordan-Austria BIT (2001) & & - & & & - & & & & & & & & \\
\hline Jordan-Canada BIT (2009) & - & & & & & $\cdot$ & - & & & & - & • & \\
\hline Jordan-Finland BIT (2006) & - & & & & $\cdot$ & & & & & & & & \\
\hline Jordan-India BIT (2006) & $\cdot$ & & & & & $\cdot$ & & & & & $\cdot$ & & \\
\hline Jordan-Kuwait BIT (2001) & $\cdot$ & & & & & $\cdot$ & & & & & & & \\
\hline Jordan-Singapore BIT (2004) & $\cdot$ & & & & & $\cdot$ & & & & & - & & \\
\hline Jordan-United States BIT (1997) & - & - & & & - & & & & & & & & \\
\hline Korea-Belgium/Luxembourg BIT (2006) & - & & & & - & 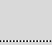 & & & & & & & \\
\hline Korea-Chile FTA (2003) & - & & & & - & - & - & & & & 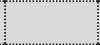 & - & \\
\hline Korea-Colombia FTA (2013) & - & & $\cdot$ & & - & $\cdot$ & . & & - & & - & $\cdot$ & \\
\hline Korea-India BIT (1996) & - & & & & 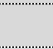 & - & 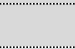 & & & & & & \\
\hline Korea-India CEPA (2009) & - & & & & . & - & - & & & & - & & \\
\hline Korea-Japan BIT (2002) & . & & & & - & - & - & & & & & & \\
\hline Korea-Peru FTA (2011) & - & - & - & - & - & - & - & & & - & - & & \\
\hline Korea-Rwanda BIT (2009) & . & - & & & • & - & & & & & - & & \\
\hline Korea-Singapore FTA (2005) & - & 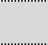 & & & S & - & 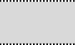 & & & & & & \\
\hline Korea-Trinidad and Tobago BIT (2002) & $\cdot$ & & & & $\cdot$ & & 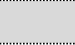 & & & & & & \\
\hline Korea-United States FTA (2007) & $\cdot$ & $\cdot$ & $\cdot$ & & $\cdot$ & $\cdot$ & - & & $\cdot$ & - & - & $\cdot$ & \\
\hline Korea-Uruguay BIT (2009) & - & - & & & - & $\cdot$ & & & & & - & & \\
\hline Latvia-Canada BIT (1995) & $\cdot$ & & & & & $\cdot$ & & & & & & & \\
\hline Latvia-Canada BIT (2009) & $\cdot$ & & & & & $\cdot$ & - & & & & - & & \\
\hline Latvia-India BIT (2010) & - & & & & & $\cdot$ & 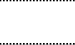 & & & & - & & \\
\hline Lithuania-India BIT (2011) & - & & & & & - & & & & & - & & \\
\hline Lithuania-United States BIT (1998) & & - & & & - & & & & & & & & \\
\hline Malaysia-Japan EPA (2005) & $\cdot$ & & & & & & - & & & & & & \\
\hline Malaysia-New Zealand FTA (2009) & • & - & & & - & - & 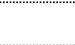 & & & & - & & \\
\hline Mexico-Austria BIT (1998) & & & & & & & & & & & & & - \\
\hline Mexico-Bolivia FTA (1994) & - & - & & & - & - & - & & & & & & \\
\hline Mexico-Chile FTA (1998) & $\cdot$ & $\cdot$ & & & $\cdot$ & $\cdot$ & - & & & & & $\cdot$ & \\
\hline Mexico-Colombia FTA (1994) & $\cdot$ & $\cdot$ & & & $\cdot$ & & - & & & & & & \\
\hline Mexico-Costa Rica FTA (1994) & $\cdot$ & $\cdot$ & & & $\cdot$ & $\cdot$ & - & & & & & & \\
\hline Mexico-Cuba BIT (2001) & - & & & & & - & & & & & & & \\
\hline Mexico-Japan EPA (2004) & - & & & & & - & - & & & & & - & \\
\hline Mexico-Nicaraqua FTA (1997) & - & - & & & - & - & - & & & & & & \\
\hline Mexico-Peru FTA (2011) & - & & & & & - & - & & & & - & - & \\
\hline Mexico-Switzerland BIT (1995) & - & & & & & & - & & & & & & \\
\hline Mexico-Trinidad and Tobago BIT (2006) & - & & & & & & - & & & & & & \\
\hline Mexico-United Kingdom BIT (2006) & • & & & & & & & & & & & - & \\
\hline Mexico-Uruguay FTA (2003) & $\cdot$ & & & & & - & & & & & & & \\
\hline Morocco-United States FTA (2004) & - & • & - & & - & - & - & & - & - & & - & \\
\hline
\end{tabular}




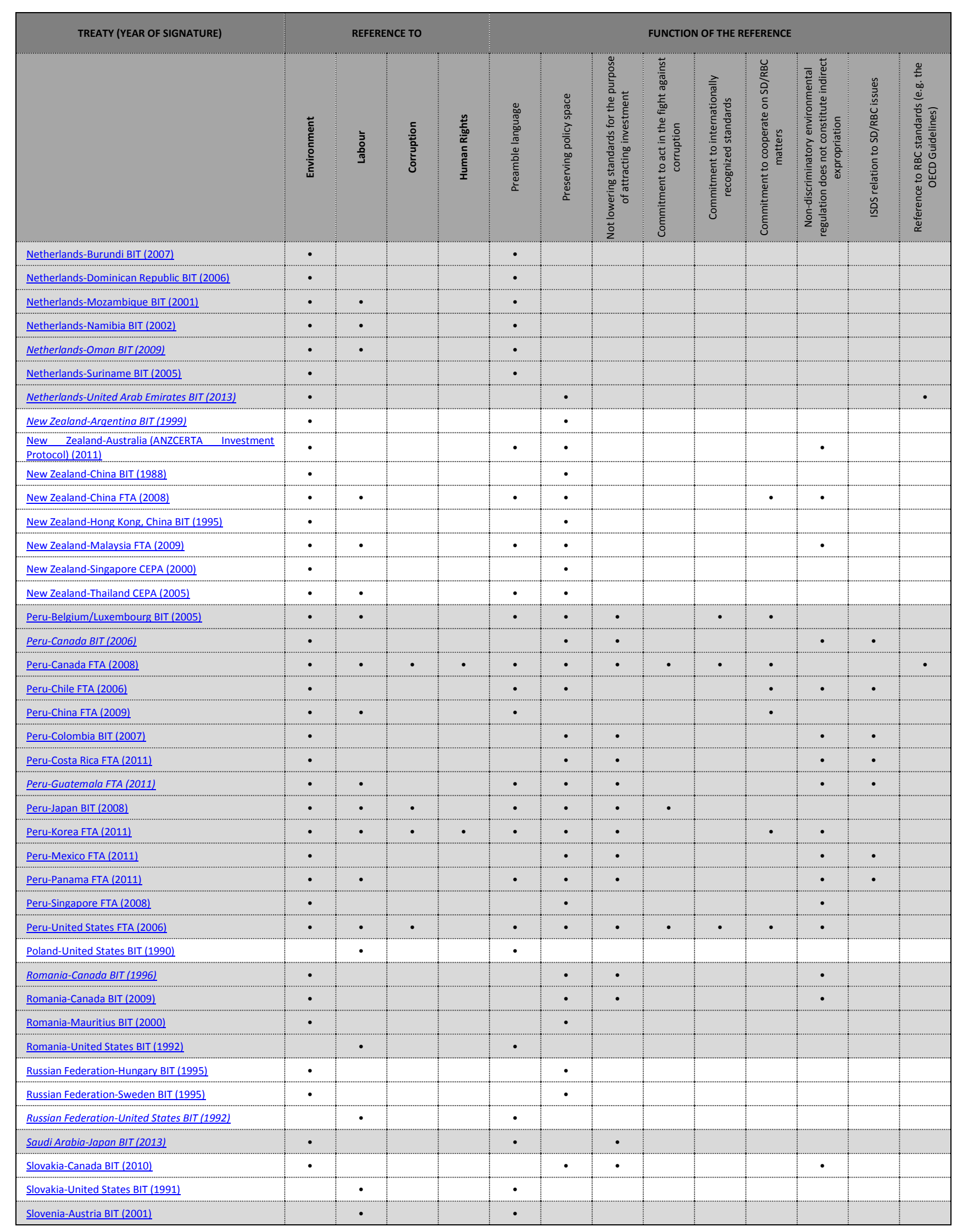




\begin{tabular}{|c|c|c|c|c|c|c|c|c|c|c|c|c|c|}
\hline \multirow[t]{2}{*}{ TREATY (YEAR OF SIGNATURE) } & \multicolumn{4}{|c|}{ REFERENCE TO } & \multicolumn{9}{|c|}{ FUNCTION OF THE REFERENCE } \\
\hline & 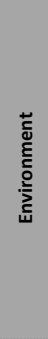 & $\begin{array}{l}\frac{\mathrm{z}}{2} \\
\frac{0}{9}\end{array}$ & 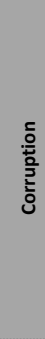 & 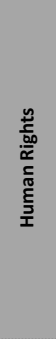 & 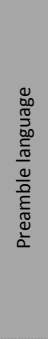 & 迩 & 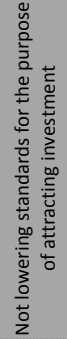 & 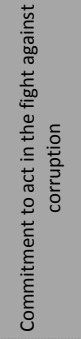 & 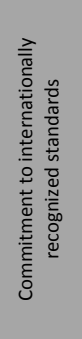 & 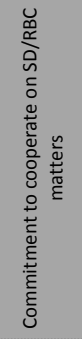 & 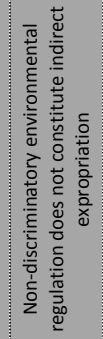 & 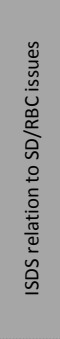 & 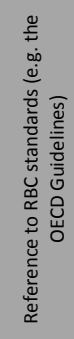 \\
\hline Slovenia-India BIT (2011) & - & & & & & - & & & & & - & & \\
\hline South Africa-Canada BIT (1995) & $\cdot$ & & & & & - & & & & & & & \\
\hline Spain-Libva BIT (2007) & - & & & & - & - & - & & & & & & \\
\hline Sweden-Georgia BIT (2008) & $\cdot$ & & & & $\cdot$ & & & & & & & & \\
\hline Sweden-Mauritius BIT (2004) & $\cdot$ & & & & $\cdot$ & & & & & & & & \\
\hline Sweden-Russian Federation BIT (1995) & $\cdot$ & & & & & $\cdot$ & & & & & & & \\
\hline Switzerland-Egypt BIT (2010) & - & & & & - & & & & & & & & \\
\hline Switzerland-EI Salvador BTT (1994) & - & & & & & - & & & & & & & \\
\hline $\begin{array}{l}\text { Switzerland-Japan EPA (2009) } \\
\end{array}$ & - & - & & $\cdot$ & - & & - & & & & & & \\
\hline Switzerland-Kosovo BIT (2011) & - & - & - & & - & & & & & & & & - \\
\hline Switzerland-Madagascar BIT (2008) & - & & & & - & - & & & & & & & \\
\hline Switzerland-Mauritius BIT (1998) & - & & & & & - & & & & & & & \\
\hline Switzerland-Mexico BIT (1995) & - & & & & . & & - & & & & & & \\
\hline Switzerland-Mozambique BIT (2002) & - & & & & - & & & & & & & & \\
\hline Switzerland-Syria BIT (2007) & $\cdot$ & & & & . & & & & & & & & \\
\hline Switzerland-Trinidad and Tobago BIT (2010) & - & & & & • & . & & & & & & & \\
\hline Switzerland-Tunisia BIT (2012) & . & & & & • & & & & & & & & \\
\hline Tunisia-Switzerland BIT (2012) & - & & & & - & & & & & & & & \\
\hline Turkey-Nigeria BIT (2011) & $\cdot$ & $\cdot$ & & & - & $\cdot$ & & & & & & & \\
\hline United Kingdom-Colombia BIT (2010) & $\cdot$ & & & & . & $\cdot$ & & & & & $\cdot$ & & \\
\hline United Kingdom-Mexico BIT (2006) & - & . & & & 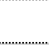 & & & & & & & - & \\
\hline United States-Albania BIT (1995) & . & - & & & - & & & & & & & & \\
\hline United States-Argentina BIT (1991) & & - & & & - & & & & & & & & \\
\hline United States-Armenia BIT (1992) & & - & & & - & & & & & & & & \\
\hline United States-Australia FTA (2004) & - & - & & & - & - & - & & - & - & - & & \\
\hline United States-Azerbaijan BIT (1997) & - & - & & & - & & & & & & & & \\
\hline United States-Bahrain BIT (1999) & - & - & & & . & & & & & & & & \\
\hline United States-Bolivia BIT (1998) & - & - & & & - & & & & & & & & \\
\hline United States-Bulgaria BIT (1992) & & • & & & . & & & & & & & & \\
\hline United States-Chile FTA (2003) & - & - & & & - & - & - & & - & - & - & - & \\
\hline United States-Croatia BIT (1996) & $\cdot$ & $\cdot$ & & & $\cdot$ & & & & & & & & \\
\hline United States-Czech Republic BIT (1991) & & - & & & $\cdot$ & & & & & & & & \\
\hline United States-Ecuador BIT (1993) & & - & & & - & & & & & & & & \\
\hline United States-EI Salvador BIT (1999) & - & - & & & - & & & & & & & & \\
\hline United States-Estonia BIT (1994) & & - & & & - & & & & & & & & \\
\hline United States-Georgia BIT (1994) & - & - & & & - & & & & & & & & \\
\hline United States-Honduras BT (1995) & - & - & & & - & & & & & & & & \\
\hline United States-Jamaica BIT (1994) & & - & & & - & & & & & & & & \\
\hline United States-Jordan BIT (1997) & - & - & & & - & & & & & & & & \\
\hline United States-Kazakhstan BIT (1992) & & - & & & $\cdot$ & & & & & & & & \\
\hline United States-Korea FTA (2007) & • & • & • & & $\cdot$ & • & - & & - & • & - & - & \\
\hline United States-Kyrgyzstan BIT (1993) & & - & & & • & & & & & & & & \\
\hline
\end{tabular}




\begin{tabular}{|c|c|c|c|c|c|c|c|c|c|c|c|c|c|}
\hline \multirow{2}{*}{ TREATY (YEAR OF SIGNATURE) } & \multicolumn{4}{|c|}{ REFERENCE TO } & \multicolumn{9}{|c|}{ FUNCTION OF THE REFERENCE } \\
\hline & 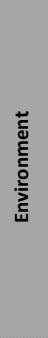 & $\begin{array}{l}\text { 亏 } \\
\frac{0}{\Xi} \\
\text { J }\end{array}$ & $\begin{array}{l}\frac{5}{0} \\
\frac{0}{2} \\
\frac{2}{2}\end{array}$ & 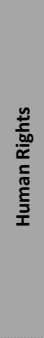 & 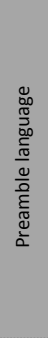 & 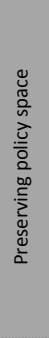 & 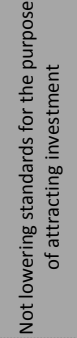 & 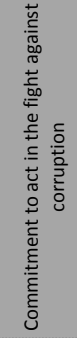 & 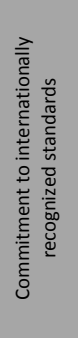 & 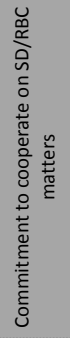 & 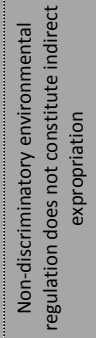 & 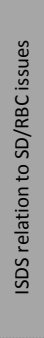 & 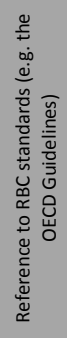 \\
\hline United States-Lithuania BIT (1998) & & - & & & - & & & & & & & & \\
\hline United States-Moldova BIT (1993) & & - & & & • & & & & & & & & \\
\hline United States-Mongolia BIT (1994) & & $\cdot$ & & & - & & & & & & & & \\
\hline United States-Morocco FTA (2004) & $\cdot$ & $\cdot$ & $\cdot$ & & $\cdot$ & • & - & & - & - & & $\bullet$ & \\
\hline United States-Mozambique BIT (1998) & - & - & & & - & & & & & & & & \\
\hline United States-Nicaragua BIT (1995) & - & - & & & • & & & & & & & & \\
\hline United States-Oman FTA (2006) & - & - & - & & - & • & - & & - & - & - & • & \\
\hline United States-Peru FTA (2006) & - & $\cdot$ & - & & - & - & - & - & - & - & $\cdot$ & & \\
\hline United States-Poland BIT (1990) & & $\cdot$ & & & - & & & & & & & & \\
\hline United States-Romania BIT (1992) & & - & & & - & & & & & & & & \\
\hline United States-Russian Federation BIT (1992) & & - & & & - & & & & & & & & \\
\hline United States-Rwanda BIT (2008) & - & - & & & • & • & - & & & & - & • & \\
\hline United States-Singapore FTA (2003) & - & - & - & & - & - & - & & - & - & & $\bullet$ & • \\
\hline United States-Slovakia BIT (1991) & & - & & & • & & & & & & & & \\
\hline United States-Sri Lanka BIT (1991) & & - & & & - & & & & & & & & \\
\hline United States-Trinidad and Tobago BIT (1994) & - & - & & & - & & & & & & & & \\
\hline United States-Ukraine BIT (1994) & & - & & & - & & & & & & & & \\
\hline United States-Uruguay BIT (2005) & - & - & & & • & • & - & & - & - & - & • & \\
\hline United States-Uzbekistan BIT (1994) & - & - & & & • & & & & & & & & \\
\hline
\end{tabular}




\section{ANNEX 2. EXAMPLES OF SD/RBC LANGUAGE IN INTERNATIONAL INVESTMENT AGREEMENTS BY FUNCTION}

This annex presents examples of language relating to responsible business conduct (RBC) inserted in investment treaties - bilateral investment treaties (BIT) and free trade agreements (FTA) -, by its function and purpose in the treaty:

(i) preamble language which serves to clarify the object and purpose of the treaty and sets the broader context relevant for interpreting the treaty;

(ii) language on preserving policy space which aims at preserving policy space for regulating in the public interest;

(iii) not lowering standards language which seeks to discourage loosening of environmental or labour regulations in order to attract investment;

(iv) language establishing that, in general, measures taken in order to protect public welfare objectives do not constitute indirect expropriation which provides that non-discriminatory regulatory actions taken in order to protect public welfare objectives, such as the protection of the environment, do not amount to an indirect expropriation;

(v) language establishing commitment to cooperate on RBC matters by which treaty partners commit to cooperate on such matters as the protection of the environment, the fight against corruption or the implementation of labour standards and the protection of human rights;

(vi) language establishing a relation between $R B C$ matters and the investor-state dispute settlement (ISDS) system which establishes a link between RBC concerns and the ISDS mechanism, providing for special proceedings when RBC issues are at stake ;

(vii) language establishing commitment to maintain or implement certain internationally recognized standards which refers to standards that the treaty partners commit to implement with respect to the fight against corruption or the protection and implementation of labour conditions and standards;

(viii) language establishing commitment to act in the fight against corruption which expresses the treaty partners' commitments to take measures with respect to the fight against corruption; and

(ix) language encouraging the respect of $R B C$ standards by which the treaty partners commit to encouraging enterprises to respect RBC standards. 


\section{(i) Preamble language}

\begin{tabular}{|c|c|c|}
\hline TREATY & $\begin{array}{l}\text { ARTICLE } \\
\end{array}$ & RELEVANT EXTRACT \\
\hline Australia-United States FTA (2004) & Preamble & $\begin{array}{l}\text { "The Government of the United States of America and the Government of Australia [...., resolved to: } \\
{[\ldots]} \\
\text { IMPLEMENT this Agreement in a manner consistent with their commitment to high labour standards, sustainable development and environmental protection; } \\
{[\ldots]} \\
\text { HAVE AGREED as follows: [...]" }\end{array}$ \\
\hline Austria-Tajikistan BIT (2010) & Preamble & $\begin{array}{l}\text { "The REPUBLIC OF AUSTRIA and the REPUBLIC OF TAIIIISTAN, hereinafter referred to as 'Contracting Parties', [...] } \\
\text { REAFFIRMING the commitments under the } 2006 \text { Ministerial declaration of the UN Economic and Social Council of Full Employment and Decent Work, } \\
\text { REFERRING to international obligations and commitments concerning respect for human rights; } \\
\text { RECOGNIIING that investment, as an engine of economic growth, can play a key role in ensuring that economic growth is sustainable; } \\
\text { COMMITTED to achieving these objectives in a manner consistent with the protection of health, safety, and the environment, and the promotion of internationally recognised labour standards; } \\
\text { EXPRESSING their belief that responsible corporate behaviour, as incorporated in the OECD Guidelines for Multinational Enterprises, can contribute to mutual confidence between enterp rises and host } \\
\text { COuntries; } \\
\text { EMPHASIIING the necessity for all governments and civil actors alike to adhere to the UN and OECD anti-corruption efforts, most notably the UN Convention against Corruption (2003); } \\
\text { TAKING note of the principles of the UN Global Compact; } \\
\text { ACKNOWLEDGING that investment agreements and multilateral agreements on the protection of environment, human rights or labour rights are meant to foster global sustainable development and that any } \\
\text { possible inconsistencies there should be resolved without relaxation of standards of protection; } \\
\text { HAVE AGREED AS FOLLOWS [...." }\end{array}$ \\
\hline Chile-United States FTA (2003) & Preamble & $\begin{array}{l}\text { "The Government of the United States of America and the Government of the Republic of Chile, resolved to: } \\
\text { [...] } \\
\text { CREATE new employment opportunities and improve working conditions and living standards in their respective territories; } \\
\text { BUILD on their respective international commitments and strengthen their cooperation on labor matters; } \\
\text { PROTECT, enhance, and enforce basic workers' rights; } \\
\text { IMPLEMENT this Agreement in a manner consistent with environmental protection and conservation; } \\
\text { PROMOTE sustainable development; } \\
\text { CONSERVE, protect, and improve the environment, including through managing natural resources in their respective territories and through multilateral environmental agreements to which they are both } \\
\text { parties; } \\
\text { PRESERVE their flexibility to safeguard the public welfare; [...] } \\
\text { HAVE AGREED as follows: [...]" }\end{array}$ \\
\hline
\end{tabular}




\begin{tabular}{|c|c|c|}
\hline Switzerland-Kosovo BIT (2011) & $\begin{array}{l}\text { Preamble } \\
\end{array}$ & $\begin{array}{l}\text { “The Swiss federal Council and the Government of the Republic of Kosovo, } \\
{[\ldots]} \\
\text { recognising the necessity to encourage and protect foreign investment with a view to promoting economic prosperity and sustainable development in the two States, } \\
\text { convinced that these objectives are achievable without infringing the general norms relating to health, safety, labour and the environment, } \\
\text { aiming to encourage investors to respect the norms and principles of corporate social responsibility internationally recognised, } \\
\text { have agreed as follows: [.... }{ }^{51}\end{array}$ \\
\hline
\end{tabular}

Unofficial translation from French original : «Le Conseil fédéral Suisse et le Gouvernement de la République du Kosovo [...] reconnaissant la nécessité d'encourager et de protéger les investissements étrangers en vue de promouvoir la prospérité économique et le développement durable des deux Etats, convaincus que ces objectifs sont réalisables sans porter atteinte aux normes d'application générale relatives à la santé, à la sécurité, au travail et à l'environnement, visant à encourager les investisseurs au respect des normes et principes de responsabilité sociale des entreprises internationalement reconnus, sont convenus de ce qui suit $[\ldots] »$. 


\section{(ii) Language on preserving policy space}

\begin{tabular}{|c|c|c|}
\hline TREATY & ARTICLE & RELEVANT EXTRACT \\
\hline Finland-Namibia BIT (2002) & $\begin{array}{l}\text { Article } 16 \\
\text { "General } \\
\text { Exceptions" }\end{array}$ & $\begin{array}{l}\text { "2. Provided that such measures are not applied in a manner which would constitute a means of arbitrary or unjustifiable discrimination by a contracting Party, or a disguised investment restriction, nothing } \\
\text { in this Agreement shall be construed as preventing the Contracting Parties from taking any measure necessary for the maintenance of public order or in circumstances of a threat to the life or health of } \\
\text { humans, animals or plants." }\end{array}$ \\
\hline $\begin{array}{l}\text { Hungary-Russian Federation BIT } \\
\underline{(1995)}\end{array}$ & $\begin{array}{l}\text { Article 2 } \\
\text { "Promotion } \\
\text { and Reciprocal } \\
\text { Protection of } \\
\text { Investments" }\end{array}$ & $\begin{array}{l}\text { "3. This Agreement shall not preclude the application of either Contracting Party of measures, necessary for the maintenance of defence, national security and public order, protection of the environment, } \\
\text { morality and public health." }\end{array}$ \\
\hline Jordan-Singapore BIT (2004) & $\begin{array}{l}\text { Article } 18 \\
\text { "General } \\
\text { Exceptions" }\end{array}$ & $\begin{array}{l}\text { "Subject to the requirement that such measures are not applied in a manner which would constitute a means of arbitrary or unjustifiable discrimination, between the Parties where like conditions prevail, or } \\
\text { a disguised restriction on investments in the territory of a Party by investors of the other Party, nothing in this Treaty shall be construed to prevent the adoption or enforcement by a Party of measures: } \\
\text { (a) necessary to protect public morals or to maintain public order; } \\
\text { (b) necessary to protect human, animal or plant life or health; } \\
\text { [1...] } \\
\text { (d) imposed for the protection of national treasures of artistic, historic or archaeological value; } \\
\text { (e) relating to the conservation of exhaustible natural resources if such measures are made effective in conjunction with restrictions on domestic production or consumption." }\end{array}$ \\
\hline NAFTA (1994) & $\begin{array}{l}\text { Article } 1114 \\
\text { "Environmental } \\
\text { measures" }\end{array}$ & $\begin{array}{l}\text { "1. Nothing in this Chapter shall be construed to prevent a Party from adopting, maintaining or enforcing any measure otherwise consistent with this Chapter that it considers appropriate to ensure that } \\
\text { investment activity in its territory is undertaken in a manner sensitive to environmental concerns [...]" }\end{array}$ \\
\hline
\end{tabular}




\section{(iii) Not lowering standards language}

\begin{tabular}{|c|c|c|}
\hline TREATY & ARTICLE & RELEVANT EXTRACT \\
\hline Austria-Kosovo BIT (2010) & $\begin{array}{l}\text { Article } 5 \\
\text { "Investment } \\
\text { and Labour" }\end{array}$ & $\begin{array}{l}\text { "(1) The Contracting Parties recognise that it is inappropriate to encourage an investment by weakening domestic labour laws. } \\
\text { (2) For the purposes of this Article, "labour laws" means each Contracting Party's statutes or regulations, that are directly related to the following internationally recognised labour rights: } \\
\text { (a) the right of association; } \\
\text { (b) the right to organise and to bargain collectively; } \\
\text { (c) a prohibition on the use of any form of forced or compulsory labour; } \\
\text { (d) labour protections for children and young people, including a minimum age for the employment of children and the prohibition and elimination of the worst forms of child labour; } \\
\text { (e) acceptable conditions of work with respect to minimum wages, hours of work, and occupational safety and health. } \\
\text { (f) elimination of discrimination in employment and occupation." }\end{array}$ \\
\hline Finland-Namibia BIT (2002) & Preamble & $\begin{array}{l}\text { "The Government of the Republic of Finland and the Government of the Republic of Namibia, } \\
{[\ldots]} \\
\text { AGREEING that these objectives can be achieved without relaxing health, safety and environmental measures of general application; } \\
{[\ldots]} \\
\text { HAVE AGREED as follows: [... }]^{\prime \prime \prime}\end{array}$ \\
\hline Mexico-Switzerland BIT (1995) & $\begin{array}{l}\text { Addendum No. } \\
3 \text { of the } \\
\text { Protocol }\end{array}$ & $\begin{array}{l}\text { "The Parties recognize that it is inappropriate to encourage investment by relaxing domestic health, safety or environmental measures. Accordingly, neither Party should waive or otherwise derogate from, or } \\
\text { offer to waive or derogate, such measures as an encouragement for the establishment, acquisition, expansion or retention in its territory of an investment of an investor. If either Party considers that the } \\
\text { other Party has offered such an encouragement, it may request consultations. } \\
\text { The Parties recognize that the entry and the expansion of investments in their territory by investors of the other Party shall be subject to relevant instruments of the Organization for Economic Cooperation } \\
\text { and Development (OECD) in the field of international investments." }\end{array}$ \\
\hline Morocco-United States FTA (2004) & $\begin{array}{l}\text { Article } 16.2 \\
\text { "Application } \\
\text { and } \\
\text { Enforcement of } \\
\text { Labor Laws" }\end{array}$ & $\begin{array}{l}\text { "2. Each Party recognizes that it is inappropriate to encourage trade or investment by weakening or reducing the protections afforded in domestic labor laws. Accordingly, each Party shall strive to ensure } \\
\text { that it does not waive or otherwise derogate from, or offer to waive or otherwise derogate from, such laws in a manner that weakens or reduces adherence to the internationally recognized labor rights } \\
\text { referred to in Article } 16.7 \text { as an encouragement for trade with the other Party, or as an encouragement for the establishment, acquisition, expansion, or retention of an investment in its territory." }\end{array}$ \\
\hline
\end{tabular}


(iv) Language establishing that, in general, measures taken in order to protect public welfare objectives do not constitute indirect expropriation

\begin{tabular}{|c|c|c|}
\hline TREATY & ARTICLE & RELEVANT EXTRACT \\
\hline Canada-Romania BIT (2009) & $\begin{array}{l}\text { Annex B } \\
\text { "Clarification of } \\
\text { Indirect } \\
\text { Expropriation" }\end{array}$ & $\begin{array}{l}\text { "Article VIII (Expropriation) of this Agreement states that: } \\
\text { Investments or returns of investors of either Contracting Party shall not be nationalized, expropriated or subjected to measures having an effect equivalent to nationalization or expropriation (hereinafter } \\
\text { referred to as "expropriation") in the territory of the other Contracting Party, except for a public purpose, under due process of law, in a non-discriminatory manner and against prompt, adequate and } \\
\text { effective compensation... } \\
\text { The Contracting Parties confirm their shared understanding that: } \\
\text { [...] } \\
\text { c. Except in rare circumstances, such as when a measure or series of measures are so severe in the light of their purpose that they cannot be reasonably viewed as having been adopted and } \\
\text { applied in good faith, non-discriminatory measures of a Contracting Party that are designed and applied to protect legitimate public welfare objectives, such as health, safety and the environment, } \\
\text { do not constitute indirect expropriation." }\end{array}$ \\
\hline India-Mozambique BIT (2009) & $\begin{array}{l}\text { Article } 3 \text { of the } \\
\text { Annexure } \\
\text { "Interpretation of } \\
\text { 'Expropriation' in } \\
\text { Article } 5 \\
\text { (Expropriation)" }\end{array}$ & $\begin{array}{l}\text { "Except in rare circumstances, non-discriminatory regulatory actions by a Party that are designed and applied to protect legitimate public welfare objectives including health, safety and the environment } \\
\text { concerns do not constitute expropriation or nationalization." }\end{array}$ \\
\hline Korea-Rwanda BIT (2009) & $\begin{array}{l}\text { Article 5.4" } \\
\text { Expropriation" }\end{array}$ & $\begin{array}{l}\text { "Except in rare circumstances, such as, for example, when an action or a series of actions are extremely severe or disproportionate in light of their purposes or effects, non-discriminatory regulatory } \\
\text { actions by a Contracting Party that are designed and applied to protect legitimate public welfare objectives, such as public health, safety, the environment, and real estate price stabilization, do not } \\
\text { constitute indirect expropriations." }\end{array}$ \\
\hline Malaysia-New Zealand FTA (2009) & $\begin{array}{l}\text { Annex } 7 \\
\text { "Expropriation" }\end{array}$ & $\begin{array}{l}\text { "5. Non-discriminatory regulatory actions by a Party that are designed and applied to achieve legitimate public welfare objectives, such as the protection of public health, safety, and the environment do } \\
\text { not constitute indirect expropriation." }\end{array}$ \\
\hline
\end{tabular}




\section{(v) Language establishing commitment to cooperate on RBC matters}

\begin{tabular}{|c|c|c|}
\hline TREATY & $\begin{array}{l}\text { ARTICLE } \\
\end{array}$ & RELEVANT EXTRACT \\
\hline $\begin{array}{l}\text { Belgium/Luxembourg-Mauritius } \\
\text { BIT (2005) }\end{array}$ & $\begin{array}{l}\text { Article } 5 \\
\text { "Environment" }\end{array}$ & $\begin{array}{l}\text { - The Contracting Parties recognise that co-operation between them provides enhanced opportunities to improve environmenta } \\
\text { ntracting Party shall accept to hold expert consultations on any matter falling under the purpose of this Article." }\end{array}$ \\
\hline Chile-Colombia FTA (2006) & $\begin{array}{l}\text { Article } 20.7 \\
\text { "Anti- } \\
\text { corruption" }\end{array}$ & $\begin{array}{l}\text { "Declaration of principles } \\
\text { 1. The Parties affirm their commitment to prevent and combat corruption, including bribery, in international trade and investment. } \\
\text { 2. The Parties commit to promote, facilitate and support international cooperation for the prevention and the fight against corruption. } \\
\text { Cooperation in International Fora } \\
\text { 3. The Parties recognize the importance of regional and multilateral initiatives to prevent and combat corruption, including bribery, in international trade and investment. The Parties shall work jointly to } \\
\text { promote and support appropriate initiatives in relevant international for a. } \\
\text { 4. The Parties reaffirm their existing rights and obligations under the } 1996 \text { Inter-American Convention Against Corruption and shall work toward the implementation of measures to prevent and combat } \\
\text { corruption consistent with the } 2003 \text { United Nations Convention Against Corruption." }\end{array}$ \\
\hline Costa-Rica-Singapore FTA $(2010)$ & $\begin{array}{l}\text { Article } 14.9 \\
\text { "Labour } \\
\text { Cooperation" }\end{array}$ & $\begin{array}{l}\text { "2. The Parties reaffirm their commitment to a high standard of labour laws, policies and practices and to seek to cooperate in the promotion of employment and better understanding and observance of the } \\
\text { principles embodied in the International Labour Organization Declaration of Fundamental Principles and Rights at Work and its Follow-up (1998). Accordingly, the Parties agree to cooperate on labour } \\
\text { matters of mutual interest and benefit, taking into account their national priorities and available resources. Cooperative activities may be in areas including, but not limited to: } \\
\text { (a) skills development and employability; } \\
\text { (b) occupational safety and health; } \\
\text { (c) industrial relations and labour-management cooperation; and } \\
\text { (d) strengthening of institutional capacities." }\end{array}$ \\
\hline Korea-United States FTA (2007) & $\begin{array}{l}\text { Article } 20.8 \\
\text { "Environmental } \\
\text { Cooperation" }\end{array}$ & $\begin{array}{l}\text { 1. The Parties recognize the importance of strengthening their capacity to protect the environment and of promoting sustainable development in concert with strengthening their trade and investment } \\
\text { relations. } \\
\text { 2. The Parties are committed to expanding their cooperative relationship in bilateral, regional, and multilateral fora on environmental matters, recognizing that such cooperation will help them achieve their } \\
\text { shared environmental goals and objectives, including the development and improvement of environmental protection, practices, and technologies. } \\
\text { 3. The Parties are committed to undertaking cooperative environmental activities pursuant to the Agreement between the Government of the United States of America and the Government of the Republic } \\
\text { of Korea on Environmental Cooperation (ECA), including activities related to implementation of this Chapter. Activities that the Parties undertake pursuant to the ECA will be coordinated and reviewed by the } \\
\text { implementation body established under the ECA. The Parties also acknowledge the importance of cooperative environmental activities in other fora. } \\
\text { 4. Each Party shall consider public comments and recommendations it receives regarding cooperative environmental activities undertaken pursuant to this Chapter and the ECA. } \\
\text { 5. Each Party shall, as appropriate, share information with the other Party and the public regarding its experiences in assessing and addressing the positive and negative environmental effects of trade } \\
\text { agreements and policies." }\end{array}$ \\
\hline
\end{tabular}

Unofficial translation from Spanish original: "Declaración de Principios - 1. Las Partes afirman su compromiso de prevenir y combatir la corrupción, incluyendo el soborno, en el comercio y la inversión internacional. 2. Las Partes se comprometen a promover, facilitar y apoyar la cooperación internacional en la prevención y lucha contra la corrupción. Cooperación en Foros Internacionales - 3. Las Partes reconocen la importancia de las iniciativas regionales y multilaterales para prevenir y combatir la corrupción, incluyendo el soborno, en el comercio y la inversión internacional. Las Partes trabajarán conjuntamente para promover y apoyar iniciativas apropiadas en los foros internacionales relevantes. 4. Las Partes reafirman sus derechos y obligaciones existentes bajo la Convención Interamericana contra la Corrupción de 1996 y trabajarán en la implementación de medidas para prevenir y combatir la corrupción de manera consistente con la Convención de las Naciones Unidas contra la Corrupción de 2003.” 


\section{(vi) Language establishing a relation between RBC matters and ISDS}

\begin{tabular}{|c|c|c|}
\hline $\begin{array}{l}\text { TREATY } \\
\end{array}$ & ARTICLE & RELEVANT EXTRACT \\
\hline Austria-Uzbekistan BIT (2000) & $\begin{array}{l}\text { Article 25 } \\
\text { "Nullification" }\end{array}$ & $\begin{array}{l}\text { "(1) Either Party to the dispute may request the annulment of an award, in whole or in part, on one or more of the following grounds, that: (a) the tribunal was not properly constituted; }(b) \text { the tribunal has } \\
\text { manifestly exceeded its powers; (c) there was corruption on the part of a member of the tribunal or on the part of a person providing decisive expertise or evidence; (d) there has been a serious departure } \\
\text { from a fundamental rule of procedure; or (e) the award has failed to state the reasons on which it is based." }\end{array}$ \\
\hline Canada-Peru BIT (2006) & $\begin{array}{l}\text { Article } 42 \\
\text { "Expert } \\
\text { Reports" }\end{array}$ & $\begin{array}{l}\text { "Without prejudice to the appointment of other kinds of experts where authorized by the applicable arbitration rules, a Tribunal, at the request of a disputing party or, unless the disputing parties } \\
\text { disapprove, on its own initiative, may appoint one or more experts to report to it in writing on any factual issue concerning environmental, health, safety or other scientific matters raised by a disputing party } \\
\text { in a proceeding, subject to such terms and conditions as the disputing parties may agree." }\end{array}$ \\
\hline Chile-Japan EPA (2007) & $\begin{array}{l}\text { Article } 100 \\
\text { "Expert" } \\
\text { Report" }\end{array}$ & $\begin{array}{l}\text { "Without prejudice to the appointment of other kinds of experts where authorized by the applicable arbitration rules, a Tribunal, at the request of a disputing party or, except as the disputing parties agree } \\
\text { otherwise, on its own initiative, may appoint one or more experts in the fields of environmental, health, safety or other scientific matters to report to it in writing on any factual issue concerning matters of } \\
\text { their expertise raised by a disputing party in a proceeding, subject to such terms and conditions as the disputing parties may agree.". }\end{array}$ \\
\hline Morocco-United States FTA $(2004)$ & $\begin{array}{l}\text { Article 10.23 } \\
\text { "Expert" } \\
\text { Reports" }\end{array}$ & $\begin{array}{l}\text { "Without prejudice to the appointment of other kinds of experts where authorized by the applicable arbitration rules, a tribunal, at the request of a disputing party or, unless the disputing parties disapprove, } \\
\text { on its own initiative, may appoint one or more experts to report to it in writing on any factual issue concerning environmental, health, safety, or other scientific matters raised by a disputing party in a } \\
\text { proceeding, subject to such terms and conditions as the disputing parties may agree." }\end{array}$ \\
\hline
\end{tabular}




\section{(vii) Language establishing commitment to maintain or implement certain internationally recognized standards}

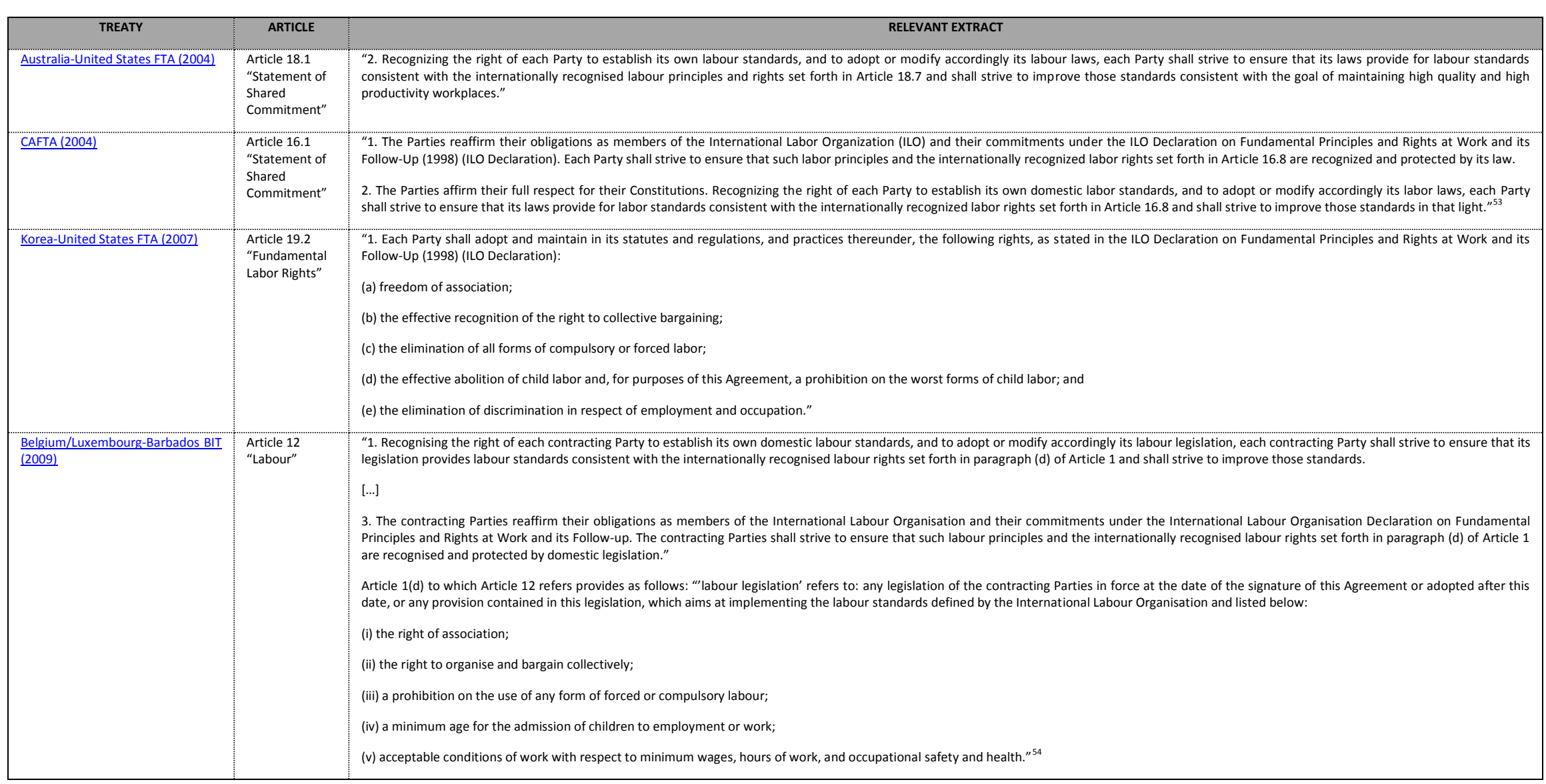

Article 16.8 of CAFTA reads as follows: "For purposes of this Chapter: labor laws means a Party's statutes or regulations, or provisions thereof, that are directly related to the following internationally recognized labor rights: (a) the right of association; (b) the right to organize and bargain collectively; (c) a prohibition on the use of any form of forced or compulsory labor; (d) a minimum age for the employment of children and the prohibition and elimination of the worst forms of child labor; and (e) acceptable conditions of work with respect to minimum wages, hours of work, and occupational safety and health. For greater certainty, the setting of standards and levels in respect of minimum wages by each Party shall not be subject to obligations under this Chapter. Each Party's obligations under this Chapter pertain to enforcing the level of the general minimum wage established by that Party." 


\section{(viii) Language establishing commitment to act in the fight against corruption}

\begin{tabular}{|c|c|c|}
\hline TREATY & ARTICLE & RELEVANT EXTRACT \\
\hline$\underline{\text { Canada-Peru FTA (2008) }}$ & $\begin{array}{l}\text { Article } 1908 \\
\text { "Anti- } \\
\text { Corruption } \\
\text { Measures" }\end{array}$ & $\begin{array}{l}\text { "1. Each Party shall adopt or maintain the necessary legislative or other measures to establish, in matters affecting international trade or investment, as criminal offences when committed intentionally: } \\
\text { (a) the solicitation or acceptance by a public official, directly or indirectly, of an undue advantage for the official himself or another person or entity, in order that the official act or refrain from acting in the } \\
\text { exercise of his official duties; } \\
\text { (b) the promise, offering or giving to a public official, directly or indirectly, of an undue advantage for the official himself or another person or entity, in order that the official act or refrain from acting in the } \\
\text { exercise of his official duties; } \\
\text { (c) the promise, offering or giving to a foreign public official or an official of a public international organization, directly or indirectly, of an undue advantage for the official himself or another person or entity } \\
\text { in order that the official act or refrain from acting in relation to the performance of official duties, in order to obtain or retain business or other undue advantage in relation to the conduct of international } \\
\text { business; and } \\
\text { (d) aiding, abetting or conspiring to commit any of the offences described in subparagraphs (a) through (c). } \\
\text { 2. Each Party shall adopt such measures as may be necessary to establish its jurisdiction over offences committed in its territory. } \\
\text { 3. Each Party shall make the commission of an offence covered by this Agreement liable to sanctions that take into account the gravity of that offence. } \\
\text { 4. Each Party shall adopt such measures as may be necessary, consistent with its legal principles, to establish the liability of enterprises for participation in the offences covered by this Agreement. In } \\
\text { particular, each Party shall ensure that enterprises held liable in accordance with this Article are subject to effective, proportionate and dissuasive criminal or non-criminal sanctions, including monetary } \\
\text { sanctions. } \\
\text { 5. Each Party shall consider incorporating in its domestic legal system at the national level appropriate measures to provide protection against any unjustified treatment for any person who reports in good } \\
\text { faith and on reasonable grounds to the competent authorities any facts concerning offences established in accordance with this Agreement." }\end{array}$ \\
\hline $\begin{array}{l}\text { Japan-Lao People's Democratic } \\
\text { Republic BIT (2008) }\end{array}$ & $\begin{array}{l}\text { Article } 10 \\
\text { "Measures } \\
\text { against } \\
\text { Corruption" }\end{array}$ & "Each Contracting Party shall ensure that measures and efforts are undertaken to prevent and combat corruption regarding matters covered by this Agreement in accordance with its laws and regulations." \\
\hline
\end{tabular}

Unofficial translation from French original: «1. Reconnaissant que chaque Partie contractante a le droit de fixer ses propres normes de protection du travail et d'adopter ou de modifier en conséquence ses lois ad hoc, chacune des Parties contractantes veillera à ce que sa législation fixe des normes de travail conformes aux normes internationales du travail énoncées au paragraphe (d) de l'Article 1 et n'aura de cesse d'améliorer lesdites normes. [...] 3. Les Parties contractantes réaffirment leurs obligations en tant que membres de l'Organisation internationale du Travail ainsi que leurs engagements en vertu de la déclaration de l'OIT relative aux principes et droits fondamentaux du travail et de son suivi. Les Parties contractantes veilleront à ce que lesdits principes et les normes internationales du travail énoncées au paragraphe (d) de l'Article 1 soient reconnus et protégés dans leur législation nationale ».

Article 1(d) to which Article 12 refers provides as follows: « 'législation du travail' désigne: toute législation des Parties contractantes en vigueur á la date de signature du présent Accord ou adoptée après cette date, ou toute disposition contenue dans cette législation, qui vise à mettre en application les normes de protection du travail énumérées ci-dessous telles que définies par l'Organisation internationale du travail: (i) le droit d'association; (ii) le droit d'organisation et de négociation collective; (iii) l'interdiction de recourir à quelque forme de travail forcé ou obligatoire que ce soit; (iv) un âge minimum d'admission des enfants à l'emploi; (v) des conditions de travail acceptables en ce qui concerne le salaire minimum et la durée du travail, ainsi que la sécurité et la santé des travailleurs ». 


\begin{tabular}{|c|c|c|}
\hline Korea-United States FTA (2007) & $\begin{array}{l}\text { Article } 21.6 \\
\text { "Anti- } \\
\text { Corruption" }\end{array}$ & $\begin{array}{l}\text { "1. The Parties reaffirm their resolve to eliminate bribery and corruption in international trade and investment. } \\
\text { 2. Each Party shall adopt or maintain the necessary legislative or other measures to establish that it is a criminal offense under its law, in matters affecting international trade or investment, for: } \\
\text { (a) a public official of the Party or a person who performs public functions for the Party intentionally to solicit or accept, directly or indirectly, any article of monetary value or other benefit, such as a favor, } \\
\text { promise, or advantage, for himself or for another person,, in exchange for any act or omission in the performance of his public functions; } \\
\text { (b) any person subject to the jurisdiction of the Party intentionally to offer or grant, directly or indirectly, to a public official of the Party or a person who performs public functions for the Party any article of } \\
\text { monetary value or other benefit, such as a favor, promise, or advantage, for himself or for another person, in exchange for any act or omission in the performance of his public functions; } \\
\text { (c) any person subject to the jurisdiction of the Party intentionally to offer, promise, or give any undue pecuniary or other advantage, directly or indirectly, to a foreign official, for that official or for another } \\
\text { person, in order that the official act or refrain from acting in relation to the performance of official duties, in order to obtain or retain business or other improper advantage in the conduct of international } \\
\text { business; and } \\
\text { (d) any person subject to the jurisdiction of the Party to aid or abet, or to conspire in, the commission of any of the offenses described in subparagraphs (a) through (c). } \\
\text { 3. Each Party shall adopt or maintain appropriate penalties and procedures to enforce the criminal measures that it adopts or maintains in conformity with paragraph 2. } \\
\text { 4. Each Party shall adopt or maintain appropriate measures to protect persons who, in good faith, report acts of bribery described in paragraph 2. } \\
\text { 5. The Parties recognize the importance of regional and multilateral initiatives to eliminate bribery and corruption in international trade and investment. The Parties shall endeavor to work jointly to } \\
\text { encourage and support appropriate initiatives in relevant international fora." }\end{array}$ \\
\hline United States-Oman FTA (2006) & $\begin{array}{l}\text { Article } 18.5 \\
\text { "Anti- } \\
\text { Corruption" }\end{array}$ & $\begin{array}{l}\text { "1. The Parties reaffirm their resolve to eliminate bribery and corruption in international trade and investment. } \\
\text { 2. Each Party shall adopt or maintain the necessary legislative or other measures to establish that it is a criminal offense under its law, in matters affecting international trade or investment, for: } \\
\text { (a) a public official of the Party or a person who performs public functions for the Party intentionally to solicit or accept, directly or indirectly, any article of monetary value or other benefit, such as a favour, } \\
\text { promise, or advantage, for himself or for another person, in exchange for any act or omission in the performance of his public functions; } \\
\text { (b) any person subject to the jurisdiction of the Party intentionally to offer or grant, directly or indirectly, to a public official of the Party or a person who performs public functions for the Party any article of } \\
\text { monetary value or other benefit, such as a favour, promise, or advantage, for himself or for another person, in exchange for any act or omission in the performance of his public functions; } \\
\text { (c) any person subject to the jurisdiction of the Party intentionally to offer, promise, or give any undue pecuniary or other advantage, directly or indirectly, to a foreign official, for that official or for another } \\
\text { person, in order that the official act or refrain from acting in relation to the performance of official duties, in order to obtain or retain business or other improper advantage in the conduct of international } \\
\text { business; and } \\
\text { (d) any person subject to the jurisdiction of the Party to aid or abet, or to conspire in, the commission of any of the offenses described in subparagraphs (a) through (c). } \\
\text { 3. Each Party shall adopt or maintain appropriate penalties and procedures to enforce the criminal measures that it adopts or maintains in conformity with paragraph 2. } \\
\text { 4. Each Party shall strive to adopt or maintain appropriate measures to protect persons who, in good faith, report acts of bribery described in paragraph 2. } \\
\text { 5. The Parties recognize the importance of regional and multilateral initiatives to eliminate bribery and corruption in international trade and investment. The Parties shall work jointly to encourage and } \\
\text { support appropriate initiatives in relevant international fora." }\end{array}$ \\
\hline
\end{tabular}




\section{(ix) Language encouraging the respect of RBC standards}

\begin{tabular}{|c|c|c|}
\hline $\begin{array}{l}\text { TREATY } \\
\end{array}$ & $\begin{array}{l}\text { ARTICLE } \\
\end{array}$ & RELEVANT EXTRACT \\
\hline Canada-Benin BIT (2013) & $\begin{array}{l}\text { Article } 16 \text { "Corpate } \\
\text { "Cocolal } \\
\text { Socia } \\
\text { Responsibility" }\end{array}$ & $\begin{array}{l}\text { "Each Contracting Party should encourage enterprises operating within its territory or subject to its jurisdiction to voluntarily incorporate internationally recognized standards of corporate social } \\
\text { responsibility in their practices and internal policies, such as statements of principle that have been endorsed or are supported by the Contracting Parties. These principles address issues such as labour, the } \\
\text { environment, human rights, community relations and anti-corruption." }\end{array}$ \\
\hline \multirow[t]{2}{*}{ Canada-Peru FTA (2008) } & Preamble & $\begin{array}{l}\text { "Canada and the Republic of Peru [...] resolved to: } \\
{[\ldots]} \\
\text { ENCOURAGE enterprises operating within their territory or subject to their jurisdiction, to respect internationally recognized corporate social responsibility standards and principles and pursue best practices; } \\
{[\ldots]} \\
\text { Have agreed as follows: [...]" }\end{array}$ \\
\hline & $\begin{array}{l}\text { Article } 810 \\
\text { "Corporate } \\
\text { Social } \\
\text { Responsibility" }\end{array}$ & $\begin{array}{l}\text { "Each Party should encourage enterprises operating within its territory or subject to its jurisdiction to voluntarily incorporate internationally recognized standards of corporate social responsibility in their } \\
\text { internal policices, such as statements of principle that have been endorsed or are supported by the Parties. These principles address issues such as labour, the environment, human rights, community relations } \\
\text { and anti-corruption. The Parties remind those enterprises of the importance of incorporating such corporate social responsibility standards in their internal policies.". }\end{array}$ \\
\hline $\begin{array}{l}\text { Netherlands-United Arab Emirates } \\
\text { BIT (2013) }\end{array}$ & $\begin{array}{l}\text { Article } 2 \\
\text { "Promotion of } \\
\text { Investments" }\end{array}$ & $\begin{array}{l}\text { "2. Both Contracting Parties recognize the right of each Contracting Party to establish its own level of domestic environmental protection and its own sustainable development policy and priorities, and to } \\
\text { adopt or modify its environmental laws and regulations and shall strive as far as possible to continue to improve their laws and regulations. } \\
\text { 3. Each Contracting Party shall promote as far as possible and in accordance with their domestic laws the application of the OECD Guidelines for Multinational Enterprises to the extent that is not contrary to } \\
\text { their domestic laws." }\end{array}$ \\
\hline
\end{tabular}




\section{ANNEX 3. USE OF RBC-RELATED INTERNATIONAL AGREEMENTS IN INVESTMENT ARBITRATION CASES}

This annex presents the international agreements relating to (i) environmental; (ii) human rights; (iii) anti-corruption and (iv) miscellaneous issues relevant to SD/RBC, referenced in investment arbitration cases. No labour-related international agreement is included in the table as no such agreement seems to have been referred to in investment arbitration cases to date.

\section{(i) Environmental Agreements}

\begin{tabular}{|c|c|c|c|}
\hline $\begin{array}{l}\text { REFERENCE OF } \\
\text { DOCUMENT }\end{array}$ & $\begin{array}{l}\text { JURISDICTIONAL } \\
\text { BASIS }\end{array}$ & $\begin{array}{l}\text { ARTICLES OF THE AGREEMENT } \\
\text { CITED }\end{array}$ & RELEVANT EXTRACT \\
\hline \multicolumn{4}{|c|}{ AARHUS PROTOCOL ON PERSISTENT ORGANIC POLLUTANTS TO THE UNECE CONVENTION ON LONG-RANGE TRANSBOUNDARY AIR POLLUTION OF 1979 (1998) } \\
\hline 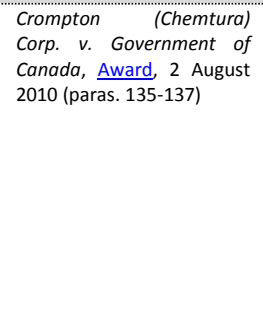 & NAFTA & $\begin{array}{l}\text { General reference to the } \\
\text { Protocol as a whole and to its } \\
\text { annex II }\end{array}$ & 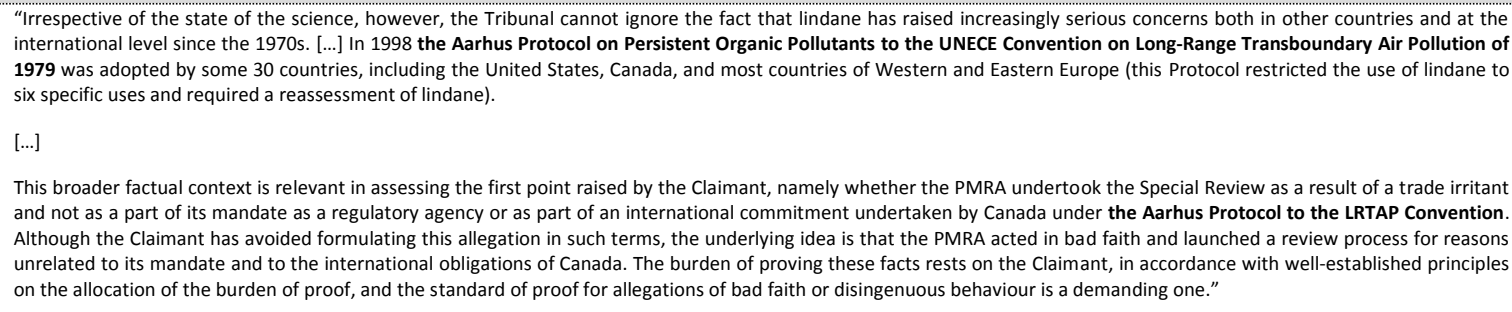 \\
\hline \multicolumn{4}{|c|}{ BASEL CONVENTION ON THE CONTROL OF TRANS-BOUNDARY MOVEMENTS OF HAZARDOUS WASTES AND THEIR DISPOSAL (1989) } \\
\hline $\begin{array}{l}\text { S.D. Myers, Inc. v. } \\
\text { Government of Canada, } \\
\text { UNCITRAL, Partial Award, } \\
13 \text { November } 2000 \text { (parass. } \\
105-109, \quad 201-215, \quad 221 \text {, } \\
\text { 255) }\end{array}$ & NAFTA & $\begin{array}{l}\text { General reference to the } \\
\text { Convention as a whole }\end{array}$ & 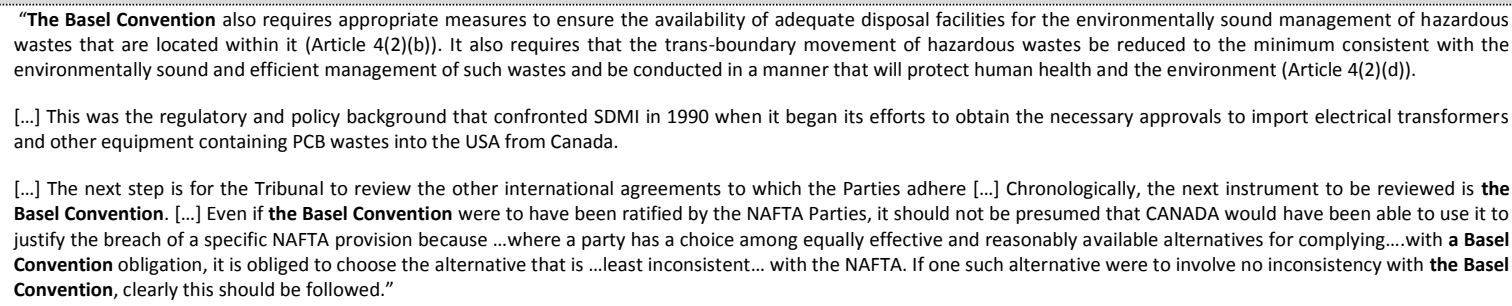 \\
\hline
\end{tabular}




\begin{tabular}{|c|c|c|c|}
\hline $\begin{array}{l}\text { REFERENCE OF } \\
\text { DOCUMENT }\end{array}$ & $\begin{array}{l}\text { JURISDICTIONAL } \\
\text { BASIS }\end{array}$ & $\begin{array}{c}\text { ARTICLES OF THE AGREEMENT } \\
\text { CITED }\end{array}$ & RELEVANT EXTRACT \\
\hline 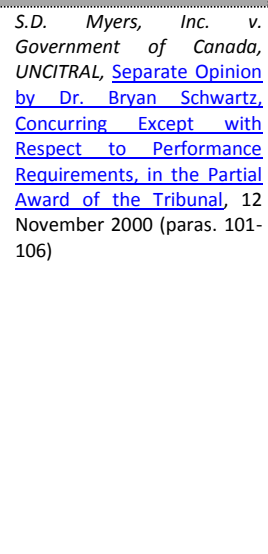 & NAFTA & $\begin{array}{l}\text { General reference to the } \\
\text { Convention as a whole }\end{array}$ & $\begin{array}{l}\text { "The Basel Convention on the Control of Transboundary Movements of Hazardous Wastes and Their Disposal was signed by } 105 \text { states in } 1989 \text {. It came into force in May } 1992 \text {, } \\
\text { when twenty states had ratified it. Canada has become a party to it. The United States had not. } \\
\text { [...] } \\
\text { It would be fair to say that the Basel Convention is not as strong as the Transboundary Agreement in emphasizing the potential that transboundary movement has for achieving } \\
\text { economies and better protecting the environment. Article } 4(2) \text { (d) of Basel does, however, acknowledge that the environmentally sound and efficient management of waste is } \\
\text { not necessarily accomplished by avoiding transbooundary shipments. } \\
\text { Furthermore, Article } 11 \text { expressly allows parties to enter into bilateral or multilateral agreements for the transboundary movement of waste, provided that these agreements } \\
\text { do not undermine Basel's own insistence on environmentally sound management of waste. As far as Canada and the United States were concerned, Article } 11 \text { "made room" for } \\
\text { the continuation of the Transboundary Convention with its clear emphasis on including transboundary movements as a means to be considered in achieving the most cost- } \\
\text { effective and environmentally-friendly solution to hazardous waste problems. } \\
\text { The framers of NAFTA considered which earlier environmental treaties would prevail over the specific rules of NAFTA in case of conflict. Article } 104 \text { provided that the Basel } \\
\text { Convention would have priority if and when it was ratified by all the NAFTA parties. The United States had not done at the time of the export ban by Canada. The United States } \\
\text { was not, therefore, required to comply with Basel rules as such and Canada could not, in a NAFTA dispute, argue that a particular NAFTA rule must be subordinate to Basel. } \\
\text { Even if Basel had been ratified by all three NAFTA parties, Canada would not be able to use it freely as a shield against a specific NAFTA obligation. Rather, according to Article } \\
104 \text { of NAFTA, 'where a party has a choice among equally effective and reasonable available alternatives for complying' with a Basel obligation, it must choose the one which is } \\
\text { least inconsistent with NAFTA. If a party can find a way to comply with both NAFTA and Basel at the same time - as it appears Canada likely could have done here - it must do } \\
\text { so." }\end{array}$ \\
\hline \multicolumn{4}{|r|}{ ESPOO CONVENTION ON ENVIRONMENTAL IMPACT ASSESSMENT IN A TRANS-BOUNDARY CONTEXT (1991) } \\
\hline $\begin{array}{l}\text { Emilio Agustin Maffezini }, \\
\text { Kingdom of Spain, ICSID } \\
\text { Case No. ARB/97/7, Award } \\
\text { (Merits), } 13 \text { November } \\
2000 \text { (fn. } 17 \text { and related } \\
\text { para. 67) }\end{array}$ & $\begin{array}{l}\text { Argentina-Spain } \\
\text { BIT }\end{array}$ & $\begin{array}{l}\text { General reference to the } \\
\text { Convention as a whole }\end{array}$ & $\begin{array}{l}\text { "The Tribunal has carefully examined these contentions, since the Environmental Impact Assessment procedure is basic for the adequate protection of the environment and the } \\
\text { application of appropriate preventive measures. This is true, not only under Spanish and EEC law, but also increasingly so under international law [See for example the } \\
\text { Convention on Environmental Impact Assessment in a Trans-boundary Context, Espoo, February 25, 1991]]." }\end{array}$ \\
\hline \multicolumn{4}{|r|}{ NORTH AMERICAN AGREEMENT ON ENVIRONMENTAL COOPERATION (1993) } \\
\hline $\begin{array}{l}\text { S.D. Myers, Inc. v. } \\
\text { Government of Canada, } \\
\text { UNCITRAL, Partial Award, } \\
\text { 13 November } 2000 \text { (paras. } \\
\text { 217-221) }\end{array}$ & NAFTA & $\begin{array}{l}\text { General reference to the } \\
\text { Agreement as a whole }\end{array}$ & $\begin{array}{l}\text { "The NAAEC's Statement of Objectives include both: } \\
\text {-Article } 1 \text { (d) - support for the environmental goals and objectives of the NAFTA, and } \\
\text {-Article } 1 \text { (e) - avoidance of new barriers of distortions in cross-border trade. } \\
\text { Article } 3 \text { of the NAAEC states that: } \\
\text { Recognizing the right of each Party to establish its own levels of domestic environmental protection and environmental development policies and priorities, and to adopt or } \\
\text { modify accordingly its environmental laws and regulations, each Party shall ensure that its laws and regulations provide for high levels of environmental protection and shall } \\
\text { strive to continue to improve those laws and regulations. } \\
\text { The NAAEC mandates the creation of a Commission for Environmental Cooperation. The Council of the Commission is authorized to strengthen cooperation on environmental } \\
\text { laws and regulations. Without reducing levels of environmental protections, the Council is to consider ways to render technical requirements more compatible (NAAEC, Article } \\
\text { 93). } \\
\text { The Preamble to the NAFTA, the NAAEC and the international agreements affirmed in the NAAEC suggest that specific provisions of the NAFTA should be interpreted in light of } \\
\text { the following general principles: } \\
\text { - Parties have the right to establish high levels of environmental protection. They are not obliged to compromise their standards merely to satisfy the political or economic } \\
\text { interests of other states; } \\
\text { - Parties should avoid creating distortions to trade; environmental protection and economic development can and should be mutually supportive. } \\
\text { In the Tribunal's view, these principles are consistent with the express provisions of the Transboundary Agreement and the Basel Convention. A logical corollary of them is that } \\
\text { where a state can achieve its chosen level of environmental protection through a variety of equally effective and reasonable means, it is obliged to adopt the alternative that is }\end{array}$ \\
\hline
\end{tabular}




\begin{tabular}{|c|c|c|c|}
\hline $\begin{array}{l}\text { REFERENCE OF } \\
\text { DOCUMENT }\end{array}$ & $\begin{array}{l}\text { JURISDICTIONAL } \\
\text { BASIS }\end{array}$ & $\begin{array}{l}\text { ARTICLES OF THE AGREEMENT } \\
\text { CITED }\end{array}$ & RELEVANT EXTRACT \\
\hline & & & most consistent with open trade. This corollary also is consistent with the language and the case law arising out of the WTO family of agreements." \\
\hline 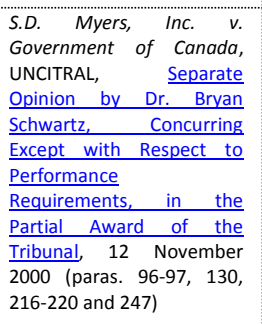 & NAFTA & $\begin{array}{l}\text { General reference to the } \\
\text { Agreement as a whole }\end{array}$ & $\begin{array}{l}\text { "The NAAEC was entered into by the parties as one of the conditions that President Clinton stipulated for approval by the United States of the main NAFTA agreement. The } \\
\text { side-by-side creation of the two agreements in itself suggests that the parties viewed open trade and environmental protection as compatible goals, and the reference to the } \\
\text { Rio Declaration makes it clearer that the goals can be viewed as mutually supportive. } \\
\text { The Vienna Convention on the Law of Treaties confirms the importance of the NAAEC to the interpretation of the provisions of NAFTA. } \\
{[\text { [...] The NAAEC's Statement of Objectives include [...]: Article 1(d) - support for the environmental goals and objectives of the NAFTA [...] }} \\
{[\text { [..] In my view, the legal context for Article } 1102 \text { (National Treatment) includes the various provisions of NAFTA, its companion agreement NAAEC and principles, including }} \\
\text { those of the Rio Declaration, that are affirmed by the NAAEC." }\end{array}$ \\
\hline \multicolumn{4}{|c|}{ OSPAR CONVENTION - CONVENTION FOR THE PROTECTION OF THE MARINE ENVIRONMENT OF THE NORTH-EAST ATLANTIC (1992) } \\
\hline $\begin{array}{l}\text { Grand River Enterprises Six } \\
\text { Nations, Ltd., et al. } v \text {. } \\
\text { United States of America, } \\
\text { UNCITRAL, Award, } 12 \\
\text { January } 2011 \text { (para. } 71 \text { and } \\
\text { fn. 8) }\end{array}$ & NAFTA & $\begin{array}{l}\text { Reference to a decision } \\
\text { rendered in application of the } \\
\text { Convention }\end{array}$ & 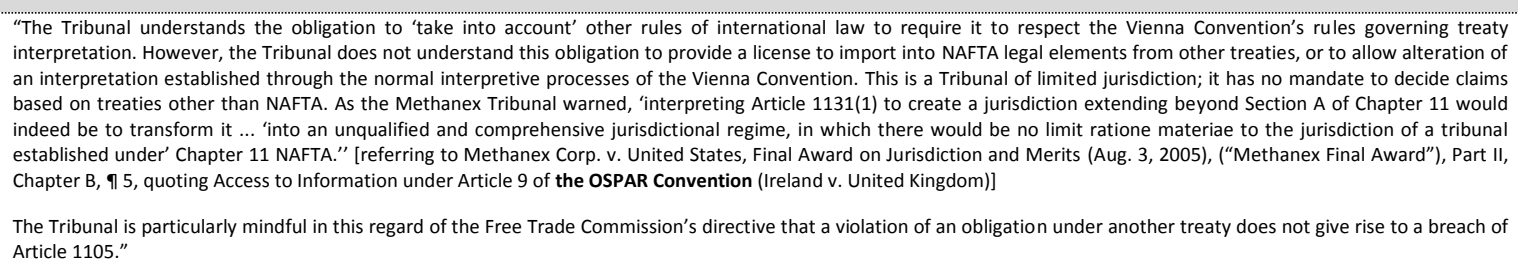 \\
\hline $\begin{array}{l}\text { Crompton (Chemtura) } \\
\text { Corp. v. Government of } \\
\text { Canada, Award, } 2 \text { August } \\
2010 \text { (para. 135) }\end{array}$ & NAFTA & $\begin{array}{l}\text { General reference to the } \\
\text { agreement as a whole }\end{array}$ & $\begin{array}{l}\text { "IIrespective of the state of the science, however, the Tribunal cannot ignore the fact that lindane has raised increasingly serious concerns both in other countries and at the } \\
\text { international level since the } 1970 \text {. [...] At the same time, a number of European countries added lindane to the List of Chemicals for Priority Action under the OSPAR } \\
\text { Convention for the Protection of the Marine Environment of the North-East Atlantic, further signalling international concern about the human health and environmental } \\
\text { effects of lindane." }\end{array}$ \\
\hline $\begin{array}{l}\text { Compañia de Aguas del } \\
\text { Aconquija S.A. and Vivendi } \\
\text { Universal S.A. v. Argentine } \\
\text { Republic, ICSID Case No. } \\
\text { ARB/97/3, Award, } 20 \\
\text { August 2007 (para. } 7.4 .3 \\
\text { and fn. 323) }\end{array}$ & $\begin{array}{l}\text { Argentine- } \\
\text { France BIT }\end{array}$ & $\begin{array}{l}\text { Reference to a decision } \\
\text { rendered in application of the } \\
\text { Convention }\end{array}$ & 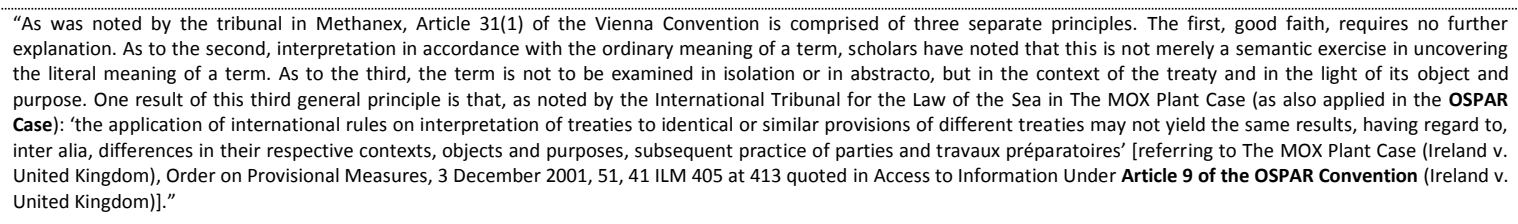 \\
\hline $\begin{array}{l}\text { Methanex Corporation v. } \\
\text { United States of America, } \\
\text { UNCITRAL, Final Award, } 3 \\
\text { August 2005 (Part II, } \\
\text { Chapter B, para. 5) }\end{array}$ & NAFTA & $\begin{array}{l}\text { General reference to the } \\
\text { Convention as a whole }\end{array}$ & 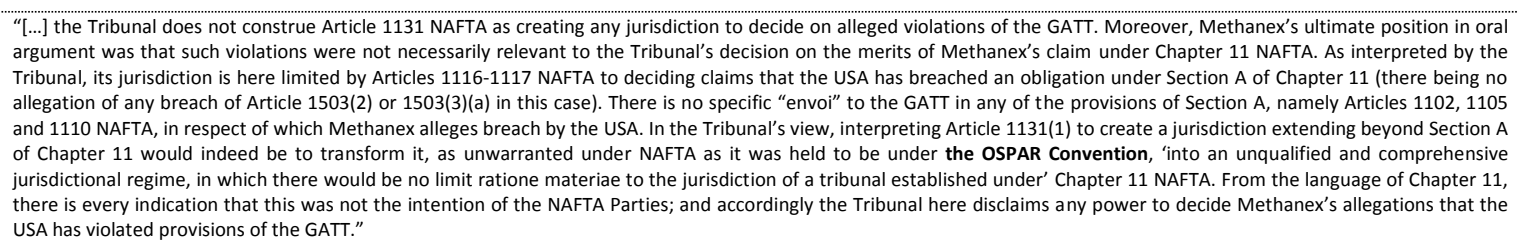 \\
\hline \multicolumn{4}{|c|}{ RESOLUTION ADOPTED BY THE GENERAL ASSEMBLY: 1803 (XVII). PERMANENT SOVEREIGNTY OVER NATURAL RESOURCES (1962) } \\
\hline $\begin{array}{l}\text { Desert Line Projects LLC v. } \\
\text { Republic of Yemen, ICSID } \\
\text { Case No. ARB/05/17, } \\
\text { Award, } 6 \text { February } 2008\end{array}$ & $\begin{array}{l}\text { Oman-Yemen } \\
\text { BIT }\end{array}$ & $\begin{array}{l}\text { General reference to the } \\
\text { Resolution as a whole }\end{array}$ & $\begin{array}{l}\text { "Although the present case doess not involve an investment in natural resources, it seems relevant to observe that the } 1962 \text { United Nations General Assembly Resolution on } \\
\text { Permanent Sovereignty over Natural Resources provides that agreements with foreign investors should be respected insofar as they are 'freely' concluded (...] The drafters } \\
\text { may have been particularly concerned with asymmetrical agreements in favour of prior colonial powers, but the principle is naturally applicable without discrimination. Indeed, } \\
\text { it should hardly be necessary to point out that where consent is vititeted, it is a universal norm that the agreement cannot be enforced against the victim of coercion." }\end{array}$ \\
\hline
\end{tabular}




\begin{tabular}{|c|c|c|c|}
\hline $\begin{array}{l}\text { REFERENCE OF } \\
\text { DOCUMENT }\end{array}$ & $\begin{array}{c}\text { JURISDICTIONAL } \\
\text { BASIS }\end{array}$ & $\begin{array}{l}\text { ARTICLES OF THE AGREEMENT } \\
\text { CITED }\end{array}$ & RELEVANT EXTRACT \\
\hline \multicolumn{4}{|l|}{ (para. 157) } \\
\hline $\begin{array}{l}\text { Yaung Chi Oo Trading PTE } \\
\text { Ltd. v. Government of the } \\
\text { Union of Myanmar, ASEAN } \\
\text { I.D. Case No. ARB/01/1, } \\
\text { Award, } 31 \text { March } 2003 \\
\text { (para. 21) }\end{array}$ & $\begin{array}{l}\text { ASEAN } \\
\text { Agreement for } \\
\text { the Promotion } \\
\text { and Protection } \\
\text { of Investments }\end{array}$ & $\begin{array}{l}\text { General reference to the } \\
\text { Resolution as a whole }\end{array}$ & $\begin{array}{l}\text { "It may be recalled that, whereas all the original ASEAN Members voted in favour of General Assembly Resolution } 1803(\mathrm{XVIII),} \mathrm{proclaiming} \mathrm{the} \mathrm{principle} \mathrm{of} \mathrm{Permanent} \\
\text { Sovereignty over Natural Resources, they all abstained on Resolution } 3281 \text { (XXIX), the Charter of Economic Rights and Duties of States, in view of its Article } 2(2) \text {, which } \\
\text { effectively denies the existence of any international standard of compensation for expropriation. ASEAN States from the beginning appear to have taken a more moderate } \\
\text { collective position with regard to the protection of foreign investments, at any rate as concerns direct foreign investments coming from within ASEAN. Hence the purpose of the } \\
1987 \text { ASEAN Agreement, which applied specifically to investments among ASEAN Member States." }\end{array}$ \\
\hline \multicolumn{4}{|r|}{ RIO DECLARATION ON ENVIRONMENT AND DEVELOPMENT (1992) } \\
\hline $\begin{array}{l}\text { LG\&E Energy Corp., LG\&E } \\
\text { Capital Corp. and LG\&E } \\
\text { International Inc. V. } \\
\text { Argentine Republic, ICSID } \\
\text { Case No. ARB/02/1, } \\
\text { Decision on Liability, } 3 \\
\text { October } 2006 \text { (paras. 252- } \\
253 \text { and fn. } 74 \text { ) }\end{array}$ & $\begin{array}{l}\text { US-Argentine } \\
\text { BIT }\end{array}$ & $\begin{array}{l}\text { Reference to Principle } 15: \text { "In } \\
\text { order to protect the } \\
\text { environment, the precautionary } \\
\text { approach shall be widely applied } \\
\text { by States according to their } \\
\text { capabilities. Where there are } \\
\text { threats of serious or irreversible } \\
\text { damage, lack of full scientific } \\
\text { certainty shall not be used as a } \\
\text { reason for postponing cost- } \\
\text { effective measures to prevent } \\
\text { environmental degradation." }\end{array}$ & $\begin{array}{l}\text { "James Crawford has stated that no opinion may be offered a priori of 'essential interest', but one should understand that it is not the case of the State's 'existence', since the } \\
\text { 'purpose of the positive law of self-defense is to safeguard that existence.' Thus, an interest's greater or lesser essential, must be determined as a function of the set of } \\
\text { conditions in which the State finds itself under specific situations. The requirement is to appreciate the conditions of each specific case where an interest is in play, since what is } \\
\text { essential cannot be predetermined in the abstract. } \\
\text { The interest must be threatened by a serious and imminent danger. The threat, according to Roberto Ago, 'must be 'extremely grave' and 'imminent."' In this respect, James } \\
\text { Crawford has opined that the danger must be established objectively and not only deemed possible. } \\
\text { [...] } \\
\text { In fact, this is so reflected in Principle } 15 \text { of the Rio Declaration on Environment and Development, adopted by the United Nations' Conference on Environment and } \\
\text { Development in 1992." }\end{array}$ \\
\hline $\begin{array}{l}\text { S.D. Myers, Inc. v. } \\
\text { Government of Canada, } \\
\text { UNCITRAL, Partial Award, } \\
13 \text { November } 2000 \text { (para. } \\
\text { 247) }\end{array}$ & NAFTA & $\begin{array}{l}\text { General reference to the } \\
\text { Declaration as a whole }\end{array}$ & $\begin{array}{l}\text { "The Tribunal considers that the legal context of Article } 1102 \text { includes the various provisions of the NAFTA, its companion agreement the NAAEC and principles that are affirmed } \\
\text { by the NAAEC (including those of the Rio declaration). The principles that emerge from that context, to repeat, are as follows: } \\
\text { - states have the right to establish high levels of environmental protection. They are not obliged to compromise their standards merely to satisfy the political or economic } \\
\text { interests of other states; } \\
\text { - states should avoid creating distortions to trade; } \\
\text { - environmental protection and economic development can and should be mutually supportive." }\end{array}$ \\
\hline $\begin{array}{l}\text { S.D. Myers, Inc. v. } \\
\text { Government of Canada, } \\
\text { UNCITRAL, } \text { Separate } \\
\text { Opinion by Dr. Bryan } \\
\text { Schwartz, Concurring } \\
\text { Except with Respect to } \\
\text { Performance } \\
\text { Requirements, in the } \\
\text { Partial Award of the } \\
\text { Tribunal, } 12 \text { November } \\
\text { 2000 (paras. } 94-96 \text { and } \\
\text { 130) }\end{array}$ & NAFTA & $\begin{array}{l}\text { General reference to the } \\
\text { Declaration as a whole }\end{array}$ & 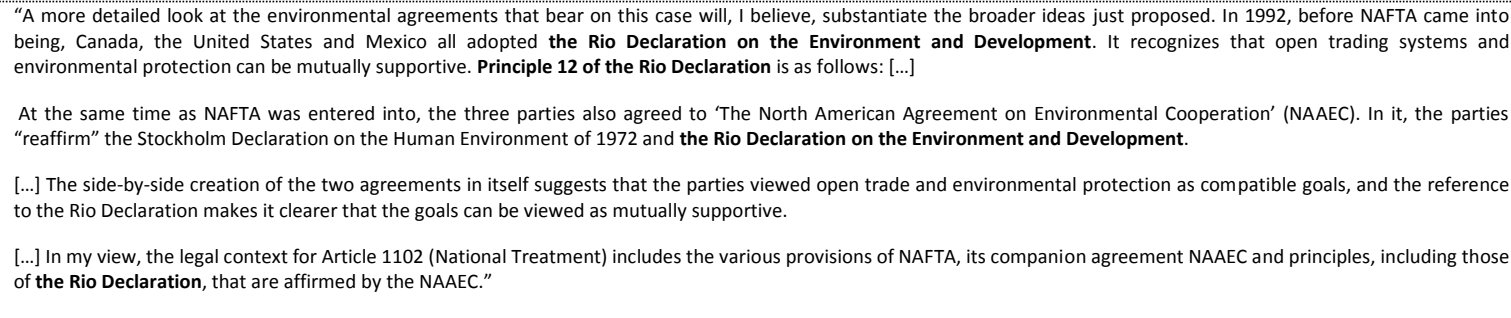 \\
\hline \multicolumn{4}{|r|}{ STOCKHOLM CONVENTION ON PERSISTENT ORGANIC POLLUTANTS (2001) } \\
\hline $\begin{array}{l}\text { Crompton (Chemtura) } \\
\text { Corp. v. Government of } \\
\text { Canada, Award, } 2 \text { August } \\
2010 \text { (paras. 135-137) }\end{array}$ & NAFTA & $\begin{array}{l}\text { General reference to the } \\
\text { Convention as a whole }\end{array}$ & $\begin{array}{l}\text { "Irrespective of the state of the science, however, the Tribunal cannot ignore the fact that lindane has raised increasingly serious concerns both in other countries and at the } \\
\text { international level since the 1970s. [...] Moreover, in May 2009, lindane was included in the list of chemicals designated for elimination under the Stockholm Convention on } \\
\text { Persistent Organic Pollutants or POPS." }\end{array}$ \\
\hline
\end{tabular}




\begin{tabular}{|c|c|c|c|}
\hline $\begin{array}{l}\text { REFERENCE OF } \\
\text { DOCUMENT }\end{array}$ & $\begin{array}{l}\text { JURISDICTIONAL } \\
\text { BASIS }\end{array}$ & $\begin{array}{l}\text { ARTICLES OF THE AGREEMENT } \\
\text { CITED }\end{array}$ & RELEVANT EXTRACT \\
\hline & & & STOCKHOLM DECLARATION ON THE HUMAN ENVIRONMENT (1972) \\
\hline 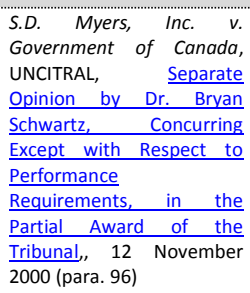 & NAFTA & $\begin{array}{l}\text { General reference to the } \\
\text { Declaration as a whole }\end{array}$ & $\begin{array}{l}\text { "At the same time as NAFTA was entered into, the three parties also agreed to 'The North American Agreement on Environmental Cooperation' (NAAEC). In it, the parties } \\
\text { "reaffirm" the Stockholm Declaration on the Human Environment of } 1972 \text { and the Rio Declaration on the Environment and Development." }\end{array}$ \\
\hline \multicolumn{4}{|c|}{ UNESCO CONVENTION CONCERNING THE PROTECTION OF THE WORLD CULTURAL PROPERTY AND NATURAL HERITAGE (1972) } \\
\hline $\begin{array}{l}\text { Glamis Gold, Ltd. v. The } \\
\text { United States of America, } \\
\text { UNCITRAL, Final Award, } 8 \\
\text { June } 2009 \text { (paras. 83-84) }\end{array}$ & NAFTA & $\begin{array}{l}\text { General reference to the } \\
\text { Convention as a whole }\end{array}$ & 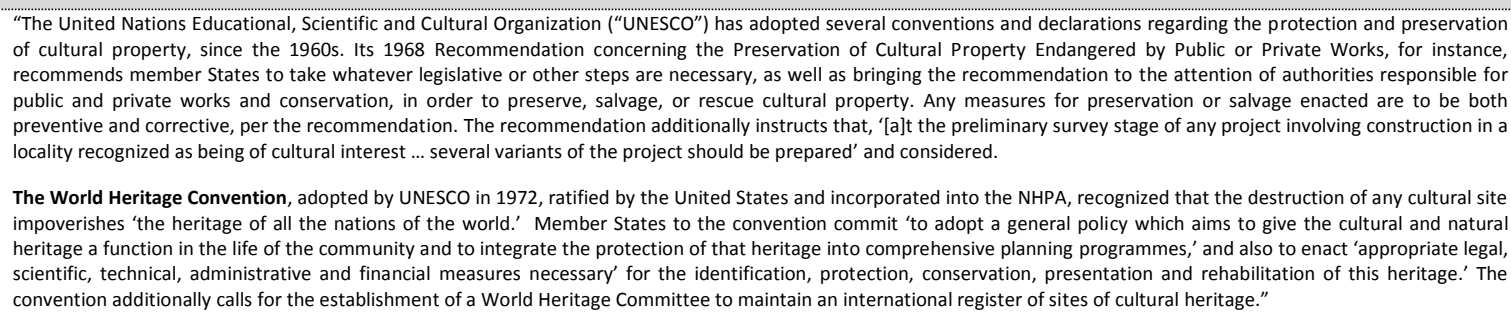 \\
\hline \multicolumn{4}{|r|}{ UNITED NATIONS CONVENTION ON THE LAW OF THE SEA (1982) } \\
\hline $\begin{array}{l}\text { Abaclat and Others (Case } \\
\text { formerly known as } \\
\text { Giovanna a Beccara and } \\
\text { Others) V. Argentine } \\
\text { Republic, ICSID Case No. } \\
\text { ARB/07/5, Dissenting } \\
\text { Opinion, Georges Abi-Saab, } \\
28 \text { October } 2011 \text { (fn. } 36 \text { ) }\end{array}$ & $\begin{array}{l}\text { Argentina-Italy } \\
\text { BIT }\end{array}$ & $\begin{array}{l}\text { General reference to the } \\
\text { Convention as a whole }\end{array}$ & $\begin{array}{l}\text { "The argument raised at one point by the Claimants, but not taken up by the majority award (though occasionally it seems to imply it), that collective mass claims actions are } \\
\text { mere multi-iparty actions as there is no recognized threshold that separates them, is extremely tenuous, verging on the absurd. International law knows several such situations. } \\
\text { For example, up to now there is no agreed or generally recognized threshold that separates air space, which is part of the territory of the State, from outer-space which is a res } \\
\text { communis. Similarly, until the Montego Bay UN Convention on the Law of the Sea of } 1982 \text {, there was no general agreement on the width of the territorial sea, i.e. on the } \\
\text { threshold that separates that sea, which his part of the territory of the State, from the high seas. But here again, the absence of an agreed threshold did not mean that these two } \\
\text { areas did not have, or prevented them from having two radically different legal status. In any case, whatever the threshold that separates, or the criterion for distinguishing, } \\
\text { multi-party actions from collective mass claims actions, it is obvious that } 60.000 \text { claims fall on the side of collective mass claims actions." }\end{array}$ \\
\hline $\begin{array}{l}\text { Mobil Corporation and } \\
\text { others v. Bolivarian } \\
\text { Republic of Venezuela, } \\
\text { ICSID Case No. ARB/07/27, } \\
\text { Decision on Jurisdiction, } 10 \\
\text { June } 2010 \text { (paras. 169-171 } \\
\text { and related fn. 107) }\end{array}$ & $\begin{array}{l}\text { Netherlands- } \\
\text { Venezuela BIT } \\
\text { (and investment } \\
\text { law) }\end{array}$ & 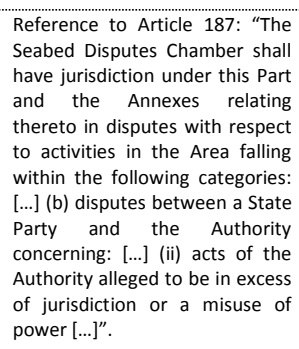 & $\begin{array}{l}\text { "The Tribunal first observes that in all systems of law, whether domestic or international, there are concepts framed in order to avoid misuse of the law. Reference may be } \\
\text { made in this respect to 'good faith' ('bonne foi'), 'détournement de pouvoir' (misuse of power) or 'abus de droit' (abuse of right). } \\
\text { The principle of good faith has been recognized by the International Court of Justice as 'one of the basic principles governing the creation and performance of legal obligations'. } \\
\text { It has been recognized in the law of treaties and has been referred to by a number of courts and tribunals including the Appellate Body of the World Trade Organisation and } \\
\text { ICSID tribunals. } \\
\text { The concept of détournement de pouvoir (misuse of power) has also been relied upon in international law, in particular in the law of the sea, the law of international } \\
\text { organisations, and in European Community law." }\end{array}$ \\
\hline $\begin{array}{l}\text { Waste Management Inc. v. } \\
\text { United Mexican States [II], } \\
\text { ICSID Case No. } \\
\text { ARB(AF)/00/3, Decision on }\end{array}$ & NAFTA & $\begin{array}{l}\text { Reference to Article 294(1): "A } \\
\text { court or tribunal provided for in } \\
\text { article } 287 \text { to which an } \\
\text { application is made in respect of }\end{array}$ & 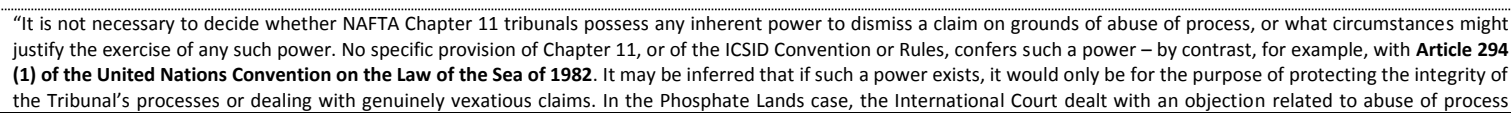 \\
\hline
\end{tabular}




\begin{tabular}{|c|c|c|c|}
\hline $\begin{array}{l}\text { REFERENCE OF } \\
\text { DOCUMENT }\end{array}$ & \multirow[t]{2}{*}{$\begin{array}{l}\text { JURISDICTIONAL } \\
\text { BASIS }\end{array}$} & \multirow[b]{2}{*}{$\begin{array}{l}\text { ARTICLES OF THE AGREEMENT } \\
\text { CITED } \\
\text { a dispute referred to in article } \\
297 \text { shall determine at the } \\
\text { request of a party, or may } \\
\text { determine proprio motu, } \\
\text { whether the claim constitutes an } \\
\text { abuse of legal process or } \\
\text { whether prima facie it is well } \\
\text { founded. If the court or tribunal } \\
\text { determines that the claim } \\
\text { constitutes an abuse of legal } \\
\text { process or is prima facie } \\
\text { unfounded, it shall take no } \\
\text { further action in the case" }\end{array}$} & RELEVANT EXTRACT \\
\hline $\begin{array}{l}\frac{\text { Mexico's } \quad \text { Preliminary }}{\text { Objection concerning the }} \\
\text { Previous Proceedings, } 26 \\
\text { June 2002 (para. 49) }\end{array}$ & & & rather summarily, although without denying that there might be some inherent power in the matter." \\
\hline \multicolumn{4}{|r|}{ UNITED NATIONS FRAMEWORK CONVENTION ON CLIMATE CHANGE (1992) } \\
\hline $\begin{array}{l}\text { Guaracachi America, Inc. } \\
\text { and Rurelec PLC V } \\
\text { Plurinational State of } \\
\text { Bolivia, PCA Case No. } 2011- \\
1 \text { 17, Award, } 31 \text { January } 2014 \\
\text { (para. 128) }\end{array}$ & $\begin{array}{l}\text { Bolivia-United } \\
\text { Kingdom BIT } \\
\text { Bolivia-United } \\
\text { States BIT }\end{array}$ & $\begin{array}{l}\text { General reference to the } \\
\text { Convention as a whole }\end{array}$ & $\begin{array}{l}\text { "The last technological project undertaken by EGSA was the CCGT. This project began in } 2007 \text { and was scheduled to start operations in May } 2010 \text {. However, it was then } \\
\text { postponed to November, which deadline was not met either. The purpose of the project- - apart from obtaining better economic and financial results-to enhance the } \\
\text { sustainable development of Bolivia through the development of state-of-the-art combined cycle technology, in accordance with the United Nations Framework Convention on } \\
\text { Climate Change. This project resulted in a series of financial benefits for GSSA, which, according to the Claimants, would be shared with the State (through the Vice-Ministry of } \\
\text { Environment and Territorial Planning) in 2007, in accordance with the applicable rules." }\end{array}$ \\
\hline \multicolumn{4}{|r|}{ UNITED STATES - MEXICO TREATY RELATING TO THE UTILIZATION OF WATER (1944) } \\
\hline $\begin{array}{l}\text { Bayview Irrigation District } \\
\text { and others v. United } \\
\text { Mexican States, ICSID Case } \\
\text { No. ARB(AF)/05/l, Award, } \\
\text { 19 June } 2007 \text { (paras. 120- } \\
\text { 122) }\end{array}$ & NAFTA & $\begin{array}{l}\text { General reference to the Treaty } \\
\text { as a whole }\end{array}$ & 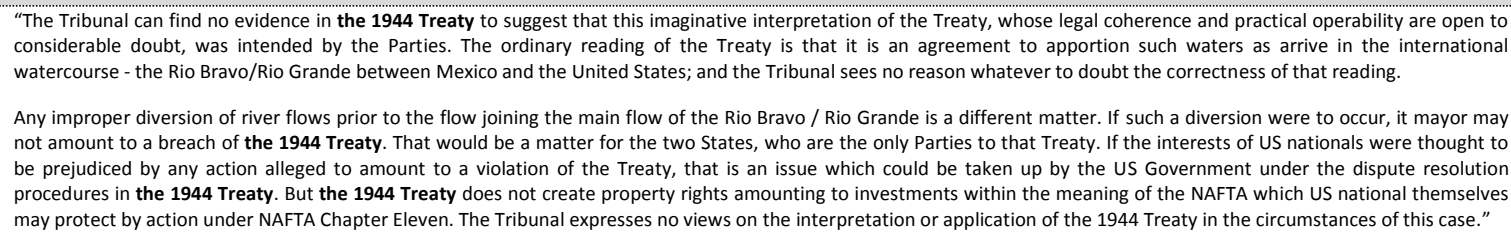 \\
\hline
\end{tabular}




\section{(ii) Human Rights Agreements}

\begin{tabular}{|c|c|c|c|}
\hline $\begin{array}{l}\text { REFERENCE OF } \\
\text { DOCUMENT }\end{array}$ & $\begin{array}{l}\text { JURISDICTIONAL } \\
\text { BASIS }\end{array}$ & $\begin{array}{l}\text { ARTICLES OF THE AGREEMENT } \\
\text { CITED }\end{array}$ & RELEVANT EXTRACT \\
\hline \multicolumn{4}{|r|}{ CHARTER OF FUNDAMENTAL RIGHTS OF THE EUROPEAN UNION (2000) } \\
\hline 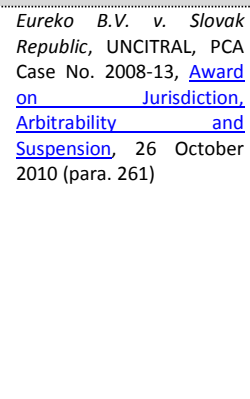 & $\begin{array}{l}\text { Netherlands- } \\
\text { Slovak Republic } \\
\text { BIT }\end{array}$ & $\begin{array}{l}\text { Reference to Article } 17(1): \\
\text { "Everyone has the right to own, } \\
\text { use, dispose of and bequeath his } \\
\text { or her lawfully acquired } \\
\text { possessions. No one may be } \\
\text { deprived of his or her } \\
\text { possessions, except in the public } \\
\text { interest and in the cases and } \\
\text { under the conditions provided } \\
\text { for by law, subject to fair } \\
\text { compensation being paid in good } \\
\text { time for their loss. The use of } \\
\text { property may be regulated by } \\
\text { law in so far as is necessary for } \\
\text { the general interest" }\end{array}$ & $\begin{array}{l}\text { "Similarly, the protection in Article } 5 \text { of the BIT against expropriation is by no means covered by the EU freedom of establishment. While it certainly overlaps with the right to to } \\
\text { property secured by Article } 17 \text { of the EU Charter of Fundamental Rights (and the First Protocol to the ECHR, as applied under EU law), the BIT provision on expropriation is not } \\
\text { obviously co-extensive with it. Both the considerable body of jurisprudence on indirect takings that has emerged in the context of BITs, and also the fact that the BIT protects } \\
\text { "assets" and "investments"s" rather than the argaubly narrower concepts o "possessions" and "property" protected by the EU Charter on Fundamental Rights, give rise to the } \\
\text { possibility of wider protection under the BIT than is enjoyed under EU law." }\end{array}$ \\
\hline \multicolumn{4}{|r|}{ CONVENTION ON THE PREVENTION AND PUNISHMENT OF THE CRIME OF GENOCIDE (1948) } \\
\hline 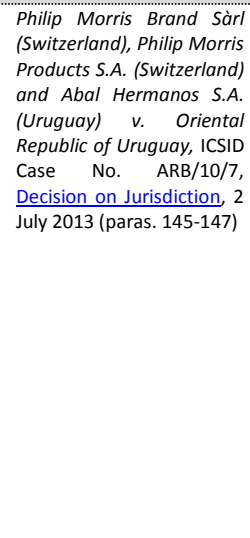 & & $\begin{array}{l}\text { Reference to a decision rendered } \\
\text { in application of the Convention }\end{array}$ & 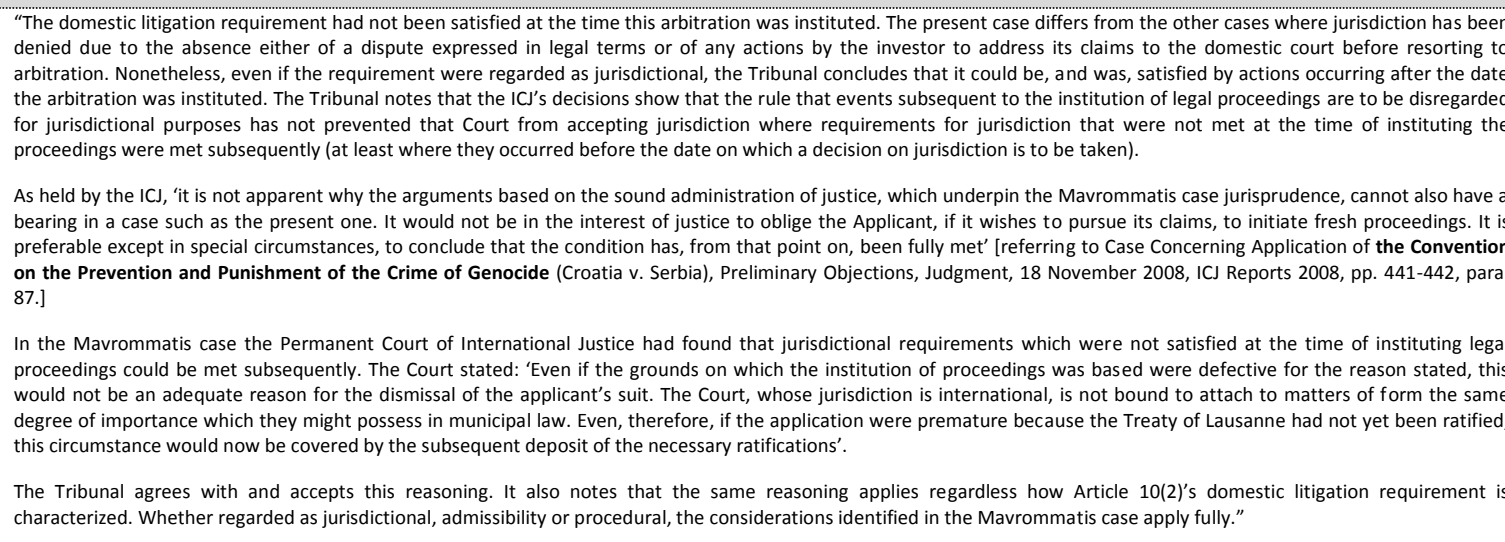 \\
\hline $\begin{array}{l}\text { Teinver S.A., Transportes } \\
\text { de Cercanias S.A. and } \\
\text { Autobuses Urbanos del Sur } \\
\text { S.A. v. Argentine Republic, } \\
\text { ICSID Case No. ARB/09/1, } \\
\text { Decision on Jurisdiction, } \\
21 \text { December } 2012 \text { (para. } \\
135 \text { and fn. 133) }\end{array}$ & $\begin{array}{l}\text { Argentina-Spain } \\
\text { BIT }\end{array}$ & $\begin{array}{l}\text { Reference to a decision rendered } \\
\text { in application of the Convention }\end{array}$ & 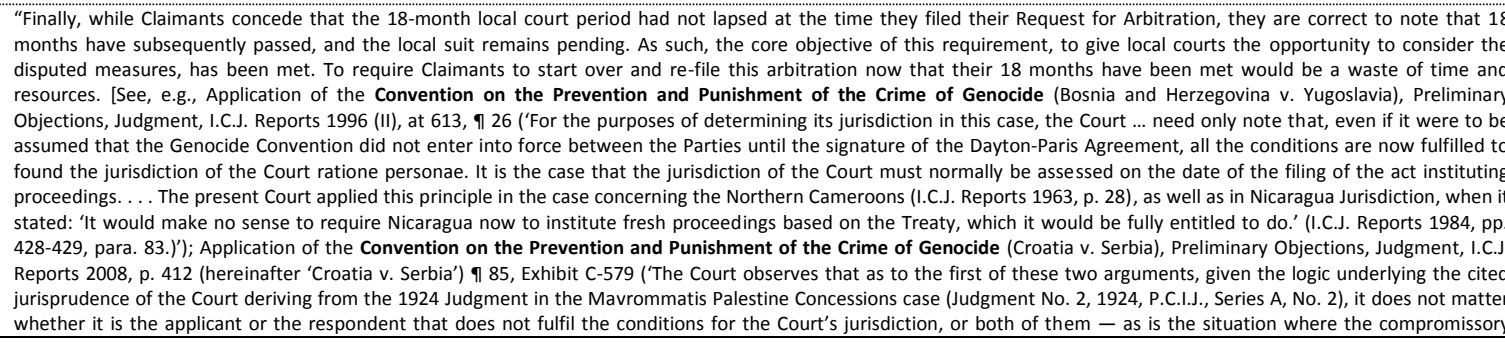 \\
\hline
\end{tabular}




\begin{tabular}{|c|c|c|c|}
\hline $\begin{array}{l}\text { REFERENCE OF } \\
\text { DOCUMENT }\end{array}$ & $\begin{array}{l}\text { JURISDICTIONAL } \\
\text { BASIS }\end{array}$ & $\begin{array}{c}\text { ARTICLES OF THE AGREEMENT } \\
\text { CITED }\end{array}$ & RELEVANT EXTRACT \\
\hline & & & $\begin{array}{l}\text { clause invoked as the basis for jurisdiction only enters into force after the proceedings have been instituted. What matters is that, at the latest by the date when the Court } \\
\text { decides on its jurisdiction, the applicant must be entitled, if it so wishes, to bring fresh proceedings in which the initially unmet condition would be fulfilled. In such a situation, it } \\
\text { is not in the interests of the sound administration of justice to compel the applicant to begin the proceedings anew - or to initiate fresh proceedings - and it is preferable, } \\
\text { except in special circumstances, to conclude that the condition has, from that point on, been fulfilled.') I)". }\end{array}$ \\
\hline $\begin{array}{l}\text { ICS Inspection and Control } \\
\text { Services Limited (United } \\
\text { Kingdom) v. Argentine } \\
\text { Republic, PCA Case No. } \\
2010-9, \text { Award on } \\
\text { Jurisdiction, } 10 \text { February } \\
2012 \text { (para. } 281 \text { and fn. } \\
308 \text { ) }\end{array}$ & $\begin{array}{l}\text { Argentina- } \\
\text { United Kingdom } \\
\text { BIT }\end{array}$ & $\begin{array}{l}\text { Reference to decisions rendered } \\
\text { with regard to the Convention }\end{array}$ & 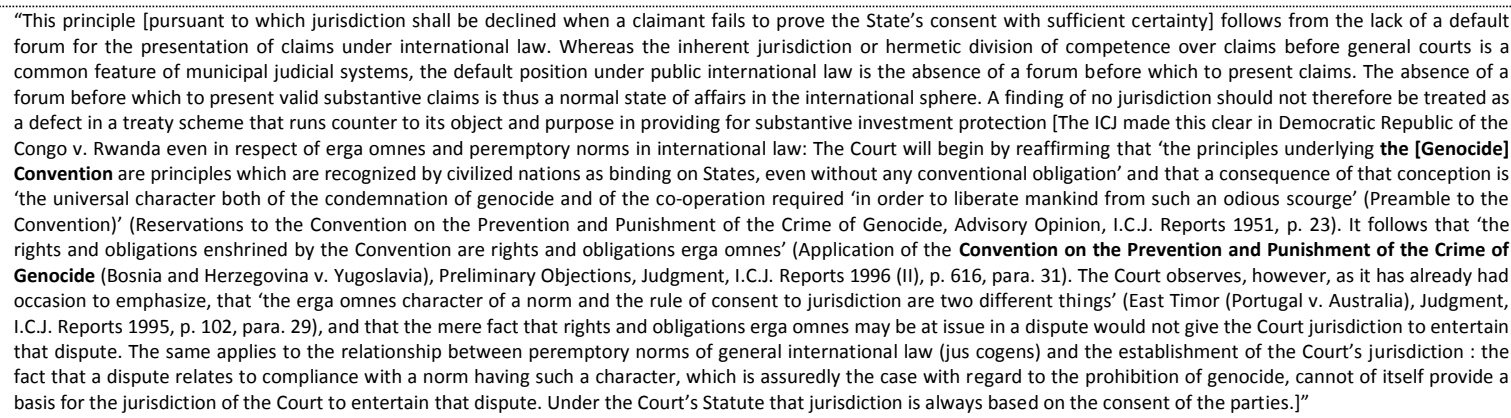 \\
\hline 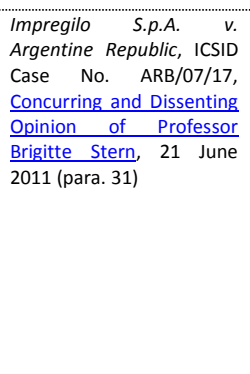 & $\begin{array}{l}\text { Argentina-Italy } \\
\text { BIT }\end{array}$ & $\begin{array}{l}\text { General reference to the } \\
\text { Convention as a whole and to its } \\
\text { Article IX: "Disputes between the } \\
\text { Contracting Parties relating to } \\
\text { the interpretation, application or } \\
\text { fulfiliment of the present } \\
\text { Convention, including those } \\
\text { relating to the responsibility of a } \\
\text { State for genocide or any of the } \\
\text { other acts enumerated in Article } \\
3 \text {, shall be submitted to the } \\
\text { linternational Court of ustitie at } \\
\text { the request of any of the parties } \\
\text { to the dispute." }\end{array}$ & 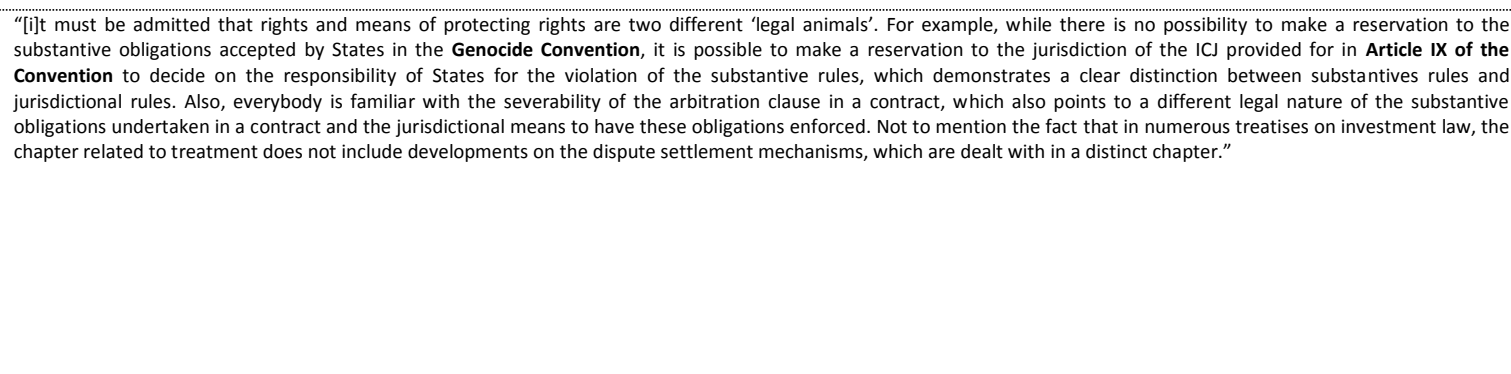 \\
\hline $\begin{array}{l}\text { Industria } \text { Nacional de } \\
\text { Alimentos, S.A. and } \\
\text { Indalsa Perú, S.A. v. v. } \\
\text { Republic of Peru, ICSID } \\
\text { Case No. ARB/03/4, } \\
\text { Decision on Annulment, } 5 \\
\text { September } 2007 \text { (para. } 86 \\
\text { and fn. 11) }\end{array}$ & Chile-Peru BIT & $\begin{array}{l}\text { Reference to a decision rendered } \\
\text { in application of the Convention }\end{array}$ & 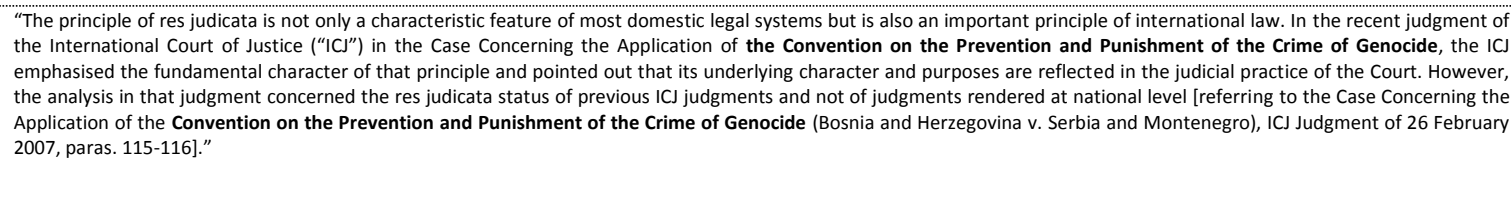 \\
\hline $\begin{array}{l}\text { United Parcel Service of } \\
\text { America Inc. } \quad \text {. } \\
\text { Government of Canada, } \\
\text { UNCITRAL, Award on the } \\
\text { Merits, } 24 \text { May } 2007 \\
\text { (para. 43) }\end{array}$ & NAFTA & $\begin{array}{l}\text { Reference to a decision rendered } \\
\text { in application of the Convention }\end{array}$ & $\begin{array}{l}\text { "The essential differences between the parties relate to the application to particular provisions of NAFTA of the law reflected in article } 31 \text { of the vienna Convention rather than } \\
\text { to the authority, relevance and understanding of that statement which, as the International Court of Justice has recently affirmed, is well recognized as part of customary } \\
\text { international law: Case Concerning the Application of the Convention on the Prevention and Punishment of the Crime of Genocide (Bosnia and Herzegovina v. Serbia and } \\
\text { Montenegro), Judgment (26 February 2007), paragraph } 160 . \text {. }\end{array}$ \\
\hline $\begin{array}{l}\text { Mondev International Ltd. } \\
v . \quad \text { United States of } \\
\text { America, ICSID Case No. } \\
\text { ARB(AF)/99/2, Award, } 11 \\
\text { October 2002 (para. } 86\end{array}$ & NAFTA & $\begin{array}{l}\text { Reference to a decision rendered } \\
\text { in application of the Convention }\end{array}$ & $\begin{array}{l}\text { "Having regard to the distinctions drawn between claims brought tunder Articles } 1116 \text { and } 11117 \text {, a NAFTA tribunal should be careful not to allow any recovery, in a claim that } \\
\text { should have been brought under Article } 1117 \text {, to be paid directly to the envestor. There are various ways of achieving this, most simply by treating such a claim as in truth } \\
\text { brought under Article } 1117 \text {, provided there has been clear disclosure in the Article } 1119 \text { notice of the substance of the claim, compliance with Article } 1121 \text { and no prejudice to } \\
\text { the Respondent State or third parties. International law does not place emphasis on merely formal considerations, nor does it require new proceedings to be commenced where } \\
\text { a merely procedural defect is involved (referring to Cf. Mavrommatis Palestine Concessions (Jurisdiction), PCIJ Ser. A No. } 2 \text { (1924) at p. 34; Case concerning Application of the }\end{array}$ \\
\hline
\end{tabular}




\begin{tabular}{|c|c|c|c|}
\hline $\begin{array}{l}\text { REFERENCE OF } \\
\text { DOCUMENT }\end{array}$ & $\begin{array}{l}\text { JURISDICTIONAL } \\
\text { BASIS }\end{array}$ & $\begin{array}{l}\text { ARTICLES OF THE AGREEMENT } \\
\text { CITED }\end{array}$ & RELEVANT EXTRACT \\
\hline and fn. 22) & & & $\begin{array}{l}\text { Convention on the Prevention and Punishment of the Crime of Genocide (Bosnia \& Herzegovina v. Yugoslavia) (Preliminary Objections) ICJ Reports } 1996 \text { p. } 595 \text { at pp. } 613-614 \\
\text { (para. 26)]." }\end{array}$ \\
\hline \multicolumn{4}{|r|}{ EUROPEAN CONVENTION FOR THE PROTECTION OF HUMAN RIGHTS AND FUNDAMENTAL FREEDOMS } \\
\hline $\begin{array}{l}\text { The Rompetrol Group N.V. } \\
\text { v. Romania, ICSID Case No. } \\
\text { ARB/06/3, Award, } 6 \text { May } \\
2013 \text { (paras. 154, 168-170, } \\
172,206-261 \text { ) }\end{array}$ & $\begin{array}{l}\text { Netherlands- } \\
\text { Romania BIT }\end{array}$ & $\begin{array}{l}\text { General reference to the } \\
\text { Convention as a whole }\end{array}$ & 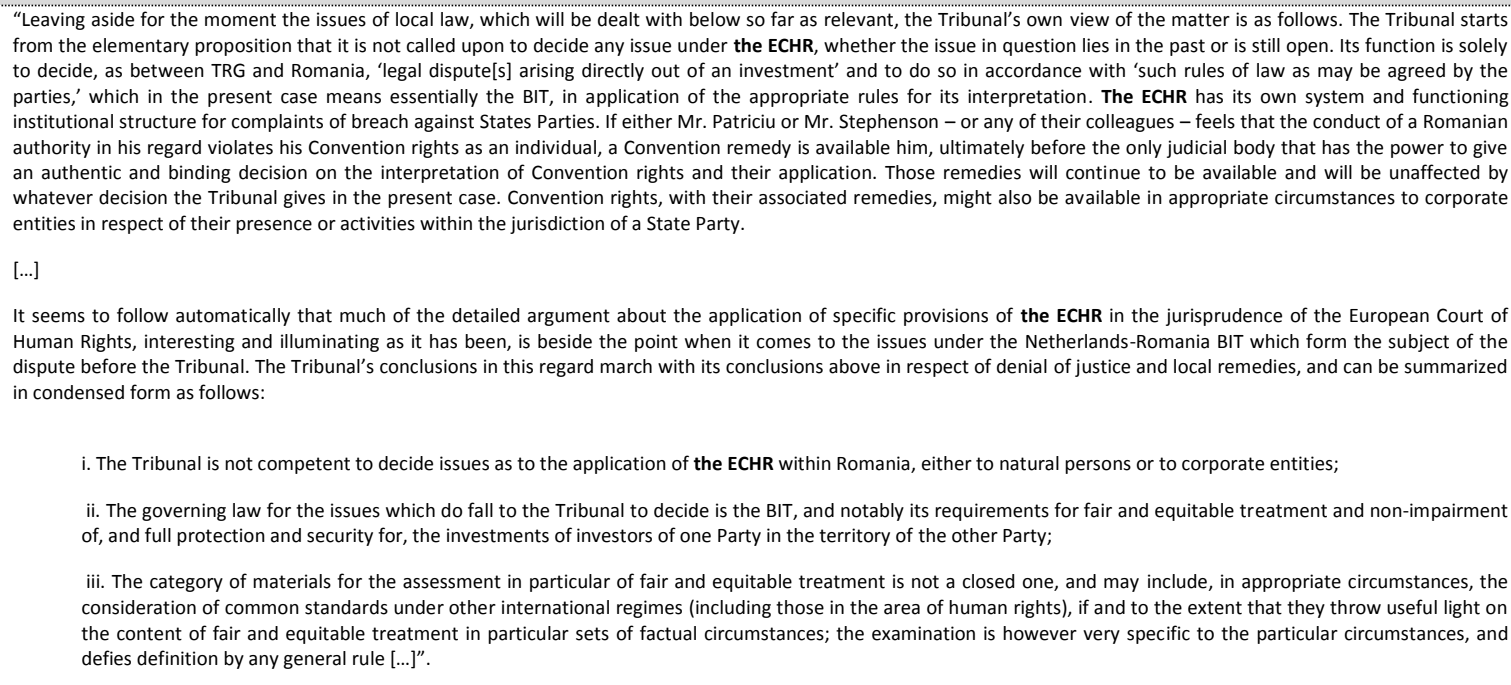 \\
\hline $\begin{array}{l}\text { Teinver S.A., Transportes } \\
\text { de Cercanias S.A. and } \\
\text { Autobuses Urbanos del Sur } \\
\text { S.A. v. Argentine Republic, } \\
\text { ICSID Case No. ARB/O9/1, } \\
\text { Decision on Jurisdiction, } \\
21 \text { December } 2012 \text { (fn. } \\
285 \text { ) }\end{array}$ & $\begin{array}{l}\text { Argentina-Spain } \\
\text { BIT }\end{array}$ & $\begin{array}{l}\text { General reference to the } \\
\text { Convention as a whole }\end{array}$ & $\begin{array}{l}\text { "Respondents also cite to European Court of Human Rights case law. [...] However, these cases involve an adjudication of a shareholder's rights under a specific instrument -the } \\
\text { ECHR-that is simply not comparable to an investment treaty." }\end{array}$ \\
\hline $\begin{array}{l}\text { Quasar de valors SICAV } \\
\text { S.A. et al. (Formerly Renta } \\
\text { 4 S.V.S.A et al.) v. Russian } \\
\text { Federation, SCC Case No. } \\
240200 \text {, Award, } 20 \text { July } \\
2012 \text { (paras. 42, 158) }\end{array}$ & $\begin{array}{l}\text { Russian } \\
\text { Federation- } \\
\text { Spain BIT }\end{array}$ & $\begin{array}{l}\text { General reference to the } \\
\text { Convention as a whole and to its } \\
\text { Protocol No. } 1\end{array}$ & 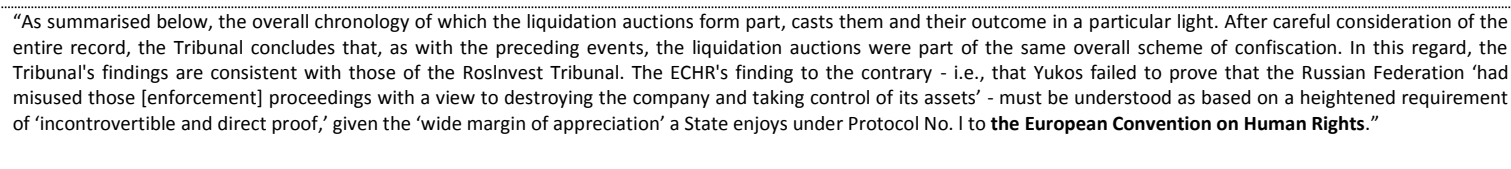 \\
\hline 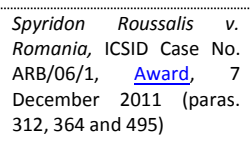 & $\begin{array}{l}\text { Greece-Romania } \\
\text { BIT }\end{array}$ & $\begin{array}{l}\text { General reference to the } \\
\text { Convention as a whole and to its } \\
\text { Protocol No. } 1\end{array}$ & $\begin{array}{l}\text { "The Tribunal does not exclude the possibility that the international obligations of the Contracting States mentioned at Article } 10 \text { of the BIT could include obligations deriving } \\
\text { from multilateral instruments to which h those states are parties, including, possibly, the European Convention of Human Rights and its Additional Protocol No.1. But the issue is } \\
\text { moot in the present case and does not require decision by the Tribunal, given the higher and more specific level of protection offered by the BIT to the investors compared to } \\
\text { the more general protections offered to them by the human rights instruments referred above. Consequently Article } 10 \text { of the BIT cannot, in its own terms and in the instant } \\
\text { case, serve as a useful instrument for enlarging the protections available to the Claimant from the Romanian State under the BIT." }\end{array}$ \\
\hline $\begin{array}{l}\text { EI } \quad \text { Paso } \quad \text { Energy } \\
\text { International Company v. } \\
\text { Argentine Republic, ICSID } \\
\text { Case No. ARB/03/15, }\end{array}$ & $\begin{array}{l}\text { Argentina-US } \\
\text { BIT }\end{array}$ & $\begin{array}{l}\text { Reference to Article } 15: \text { " }(1) \text { In } \\
\text { time of war or other public } \\
\text { emergency threatening the life of } \\
\text { the nation any High Contracting }\end{array}$ & 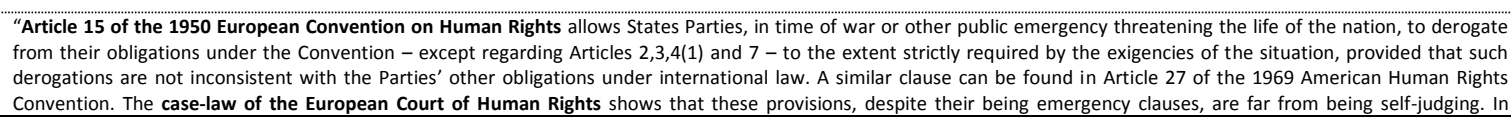 \\
\hline
\end{tabular}




\begin{tabular}{|c|c|c|c|}
\hline $\begin{array}{l}\text { REFERENCE OF } \\
\text { DOCUMENT }\end{array}$ & $\begin{array}{l}\text { JURISDICTIONAL } \\
\text { BASIS }\end{array}$ & $\begin{array}{l}\text { ARTICLES OF THE AGREEMENT } \\
\text { CITED }\end{array}$ & RELEVANT EXTRACT \\
\hline $\begin{array}{l}\text { Award, } 31 \text { October } 2011 \\
\text { (para. 598, fn. 164) }\end{array}$ & & $\begin{array}{l}\text { Party may take measures } \\
\text { derogating from its obligations } \\
\text { under this Convention to the } \\
\text { extent strictly required by the } \\
\text { exigencies of the situation, } \\
\text { provided that such masures are } \\
\text { not inconsistent with its other } \\
\text { obligations under international } \\
\text { law [...]". }\end{array}$ & $\begin{array}{l}\text { concrete cases brought before the Court and involving derogations formulated on the basis of those provisions, it is the European Court which determines whether they meet } \\
\text { the conditions provided for in Article 15." }\end{array}$ \\
\hline $\begin{array}{l}\text { loannis Kardassopoulos v. } \\
\text { Georgia, ICSID Case No. } \\
\text { ARB/05/18, Decision of } \\
\text { the ad hoc Committee to } \\
\text { Suspend the Annulment } \\
\text { Proceeding, 21 March } \\
2011 \text { (para. 16) }\end{array}$ & $\begin{array}{l}\text { Georgia-Greece } \\
\text { BIT } \\
\text { Energy Charter } \\
\text { Treaty }\end{array}$ & $\begin{array}{l}\text { General reference to the } \\
\text { Convention as a whole }\end{array}$ & $\begin{array}{l}\text { "The admissibility of the Application for Revision, much less its outcome, are no questions for the Committee to consider in light of the above developments on the distinct } \\
\text { character of the two post-award remedies offered by the ICSID Convention. The alleged violation of the European Convention on Human Rights by Georgia in relation to Mr. } \\
\text { Fuchs' arrest is a matter of no relevance, in spite of Georgaia's assertions to the contrart, in the context of deciding whether to suspend the annulment proceeding pending the } \\
\text { revision proceeding under the ICSID Convention system, and Georgia's suggestions to introduce evidence in this regard are not accepted." }\end{array}$ \\
\hline $\begin{array}{l}\text { Ron Fuchs V. Georgia, } \\
\text { ICSID Case No. ARB/07/15, } \\
\text { Decision of the ad hoc } \\
\text { Committee to Suspend the } \\
\text { Annulment Proceeding, } 21 \\
\text { March } 2011 \text { (para. 16) }\end{array}$ & $\begin{array}{l}\text { Georgia-Israel } \\
\text { BIT }\end{array}$ & $\begin{array}{l}\text { General reference to the } \\
\text { Convention as a whole }\end{array}$ & $\begin{array}{l}\text { "The admissibility of the Application for Revision, much less its outcome, are no questions for the Committee to consider in light of the above developments on the distinct } \\
\text { character of the two post-award remedies offered by the ICSID Convention. The alleged violation of the European Convention on Human Rights by Georgia in relation to Mr. } \\
\text { Fuchs' arrest is a matter of no relevance, in spitite of Georgia's sassertions to the contrar,y, in the context of deciding whether to suspend the annulment proceeding pending the } \\
\text { revision proceeding under the ICSID Convention system, and Georgia's suggestions to introduce evidence in this regard are not accepted." }\end{array}$ \\
\hline $\begin{array}{l}\text { Total S.A. V. Argentine } \\
\text { Republic, ICSID Case No. } \\
\text { ARB/04/01, Decision on } \\
\text { Liability, } 27 \text { December } \\
2010 \text { (paras. } 128-129 \text { and } \\
\text { 163) }\end{array}$ & $\begin{array}{l}\text { Argentina- } \\
\text { France BIT }\end{array}$ & $\begin{array}{l}\text { General reference to the } \\
\text { Convention as a whole and to its } \\
\text { Protocol No. } 1\end{array}$ & 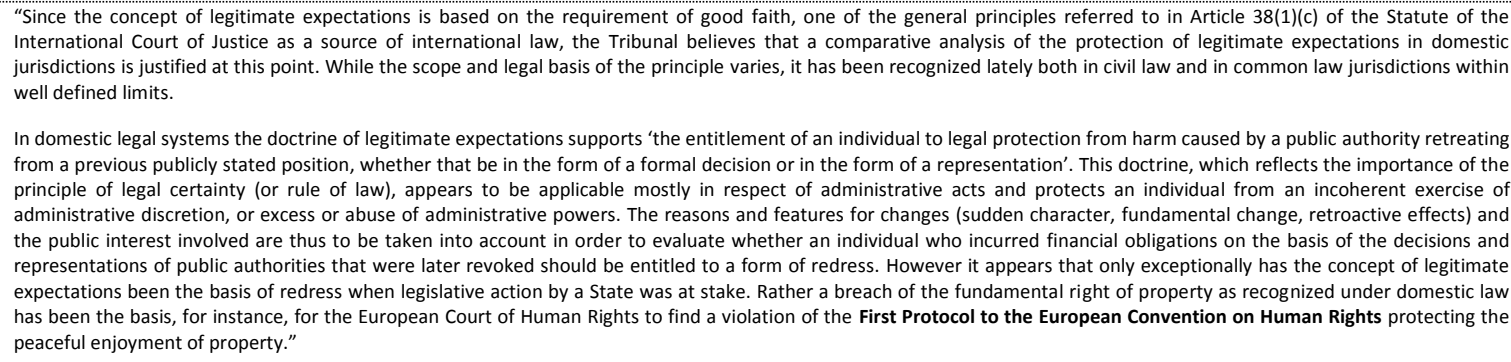 \\
\hline $\begin{array}{l}\text { Fraport AG } \begin{array}{r}\text { Frankfurt } \\
\text { Airport } \\
\text { Services }\end{array} \\
\text { Worldwide v. Republic of } \\
\text { the Philippines, ICSID Case } \\
\text { No. ARB/03/25, Decision } \\
\text { on the Application for } \\
\text { Annulment of Fraport AG } \\
\text { Frankfurt Airport Services } \\
\text { Worldwide, 23 December } \\
2010 \text { (para. 202) }\end{array}$ & $\begin{array}{l}\text { Germany- } \\
\text { Philippines BIT }\end{array}$ & $\begin{array}{l}\text { Reference to Article } 6 \text { of the } \\
\text { Convention: } \\
\text { determination of his civil rights } \\
\text { and obligations or of any criminal } \\
\text { charge against him, everyone is } \\
\text { entitled to a fair and public } \\
\text { hearing within a reasonable time } \\
\text { by an independent and impartial } \\
\text { tribunal established by law [...." }\end{array}$ & $\begin{array}{l}\text { "The right to present one's case is also accepted as an essential element of the requirement to afford a fair hearing accorded in the principal human rights instruments } \\
\text { [referring to Article } 10 \text { of the Universal Declaration of Human Rights; Article } 14 \text { of the International Covenant on Civil and Political Rights, Article } 6 \text { of the European Convention } \\
\text { for the Protection of Human Rights and Fundamental Freedoms]. This principle requires both equality of arms and the proper participation of the contending parties in the } \\
\text { procedure, these being separate but related fundamental elements of a fair trial. The principle will require the tribunal to afford both parties the opportunity to make } \\
\text { submissions where new evidence is received and considered by the tribunal to be relevant to its final deliberations. It is no answer to a failure to accord such a right that both } \\
\text { parties were equally disadvantaged." }\end{array}$ \\
\hline $\begin{array}{l}\text { loannis Kardassopoulos v. } \\
\text { Georgia, ICSID Case No. } \\
\text { ARB/05/18, Decision of } \\
\text { the ad hoc Committee on } \\
\text { the Stay of Enforcement of } \\
\text { the Award, } 12 \text { November }\end{array}$ & $\begin{array}{l}\text { Georgia-Greece } \\
\text { BIT } \\
\text { Energy Charter } \\
\text { Treaty }\end{array}$ & $\begin{array}{l}\text { Reference to Article } 6 \text { of the } \\
\text { Convention (see above) }\end{array}$ & $\begin{array}{l}\text { "The object and purpose of the Enforcement Law of } 16 \text { April } 1999 \text { are chiefly the modalities concerning execution against assets of court judgments and awards in Georgia and } \\
\text { the authority of enforcement agents. This analysis is buttressed by the Recommendations of the Council of Europe which, as an introduction, call for the necessity of the } \\
\text { implementation of judicial decisions to conform with the fair trial standards of Article } 6 \text { of the European Convention on Human Rights, a concern which does not fall within the } \\
\text { obligations undertaken by Georgia under the ICSID Convention." }\end{array}$ \\
\hline
\end{tabular}




\begin{tabular}{|c|c|c|c|}
\hline $\begin{array}{l}\text { REFERENCE OF } \\
\text { DOCUMENT }\end{array}$ & $\begin{array}{l}\text { JURISDICTIONAL } \\
\text { BASIS }\end{array}$ & $\begin{array}{l}\text { ARTICLES OF THE AGREEMENT } \\
\text { CITED }\end{array}$ & RELEVANT EXTRACT \\
\hline \multicolumn{4}{|l|}{2010 (para. 30) } \\
\hline $\begin{array}{l}\text { Ron Fuchs v. Georgia, } \\
\text { ICSID Case No. ARB/07/15, } \\
\text { Decision of the ad hoc } \\
\text { Committee on the Stay of } \\
\text { Enforcement of the } \\
\text { Award, } 12 \text { November } 2010 \\
\text { (para. 30) }\end{array}$ & $\begin{array}{l}\text { Georgia-Israel } \\
\text { BIT }\end{array}$ & $\begin{array}{l}\text { Reference to Article } 6 \text { of the } \\
\text { Convention (see above) }\end{array}$ & $\begin{array}{l}\text { "The object and purpose of the Enforcement Law of } 16 \text { April } 1999 \text { are chiefly the modalities concerning execution against assets of court judgments and awards in Georgia and } \\
\text { the authority of enforcement agents. This analysis is buttressed by the Recommendations of the Council of Europe which, as an introduction, call for the necessity of the } \\
\text { implementation of judicial decisions to conform with the fair trial standards of Article } 6 \text { of the European Convention on Human Rights, a concern which does not fall within the } \\
\text { obligations undertaken by Geoggia under the ICSID Convention." }\end{array}$ \\
\hline 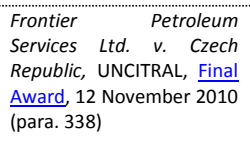 & $\begin{array}{l}\text { Canada-CZech } \\
\text { Republic BIT }\end{array}$ & $\begin{array}{l}\text { General reference to the } \\
\text { Convention as a whole }\end{array}$ & $\begin{array}{l}\text { "With respect to Claimant's argument that by operation of Articles IIII(3) and IIII) of the BIT, Claimant was entitled to the same right to expeditious proceedings before a court } \\
\text { in the Czech Republic as are persons entitled to such treatment under the ECHR, the Tribunal notes that rights under the ECHR accrue to everyone, regardless of nationality. } \\
\text { This obviates Claimant's need to rely on the BIT to invoke such rights. The Parties have not pleaded the jurisprudence of the ECHR in these proceedings, therefore this Tribunal } \\
\text { makes no finding as to whether any standard set by the ECHR is applicable here and has been breached." }\end{array}$ \\
\hline 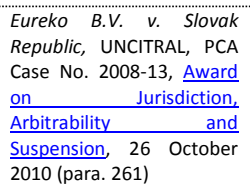 & $\begin{array}{l}\text { Netherlands- } \\
\text { Slovak Republic } \\
\text { BIT }\end{array}$ & $\begin{array}{l}\text { General reference to the first } \\
\text { protocol of the Convention }\end{array}$ & $\begin{array}{l}\text { "Similarly, the protection in Article } 5 \text { of the BIT against expropriation is by no means covered by the EU freedom of establishment. While it certainly overlaps with the right to } \\
\text { property secured by Article } 17 \text { of the EU Charter of fundamental Rights (and the First Protocol to the ECRR, as applied under EU law), the BIT provision on expropriation is not } \\
\text { obviously co-extensive with it. Both the considerable body of jurisprudence on indirect takings that has emerged in the context of BITs, and also the fact that the BIT protects } \\
\text { "assets" and "investments" rather than the arguably narrower concepts of "possessions" and "property" protected by the EU Charter on Fundamental Rights, give rise to the } \\
\text { possibility of wider protection under the BIT than is enjoyed under EU law." }\end{array}$ \\
\hline $\begin{array}{l}\text { RosInvestCo UK Ltd. V. } \\
\text { Russian Federation, SCC } \\
\text { Case No. V079/2005, Final } \\
\text { Award, } 12 \text { September } \\
2010 \text { (para. 614) }\end{array}$ & $\begin{array}{l}\text { Russian } \\
\text { Federation- } \\
\text { United Kingdom } \\
\text { BIT }\end{array}$ & $\begin{array}{l}\text { General reference to the } \\
\text { Convention as a whole }\end{array}$ & 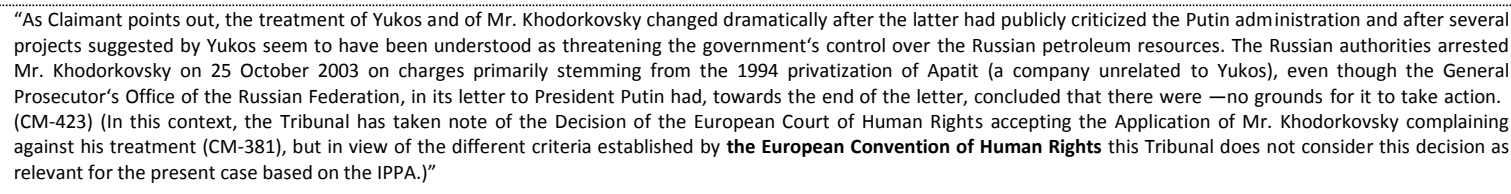 \\
\hline $\begin{array}{l}\text { The Rompetrol Group N.V. } \\
\text { v. Romania, ICSID Case No. } \\
\text { ARB/06/3, Decision of the } \\
\text { Tribunal on the } \\
\text { Participation of a Counsel, } \\
14 \text { January } 2010 \text { (paras. } \\
\text { 14-20) }\end{array}$ & $\begin{array}{l}\text { Netherlands- } \\
\text { Romania BIT }\end{array}$ & $\begin{array}{l}\text { Reference to Article } 6 \text { of the } \\
\text { Convention (see above) }\end{array}$ & 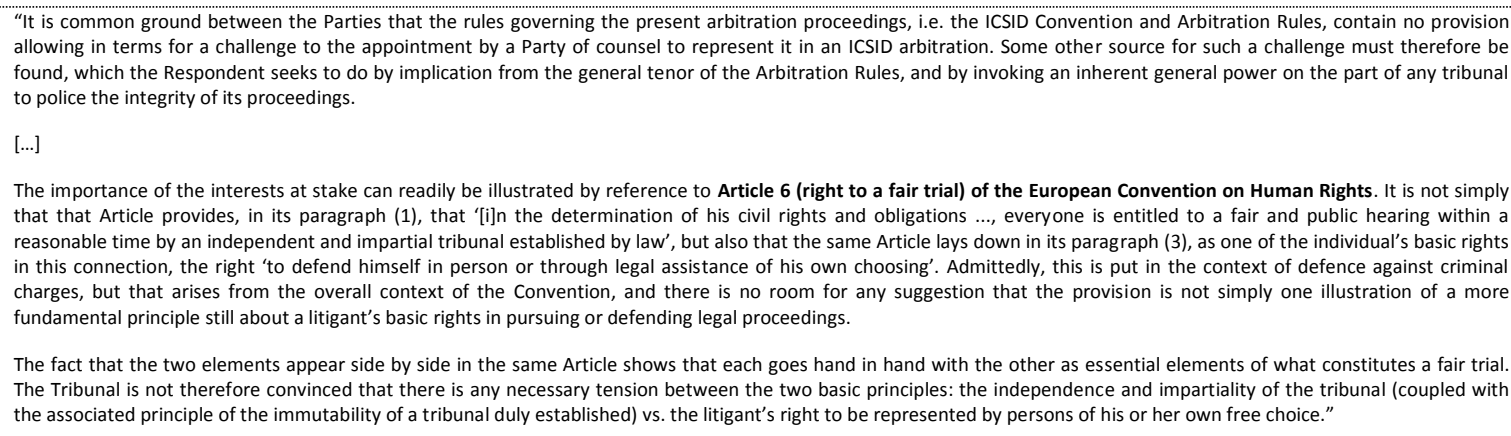 \\
\hline $\begin{array}{l}\text { Cementownia } \text { "Nowa } \\
\text { Huta" S.A. v. Republic of } \\
\text { Turkey, ICSID Case No. } \\
\text { ARB(AF)/06/2, Award, } 17 \\
\text { September 2009 (para. 98) }\end{array}$ & $\begin{array}{l}\text { Poland-Turkey } \\
\text { BIT }\end{array}$ & $\begin{array}{l}\text { General reference to the } \\
\text { Convention as a whole }\end{array}$ & $\begin{array}{l}\text { "Furthermore, CEAS and Kepez together with Kemal Uzan and Rumeli Elektrik have brought an action against the Republic of Turkey before the European Court of Human Rights } \\
\text { (ECHR) for breach of the European Convention for Human Rights and seeking damages therefor in relation to CEAS and Kepez [...] These proceedings are legally independent of } \\
\text { each other. However, the Arbitral Tribunal reserves the right to consider declarations made in such other proceedings if they are adduced as evidence in the present one." }\end{array}$ \\
\hline $\begin{array}{l}\text { Toto Costruzioni Generali } \\
\text { S.p.A. v. Republic of } \\
\text { Lebanon, ICSID Case No. }\end{array}$ & $\begin{array}{l}\text { Italy-Lebanon } \\
\text { BIT }\end{array}$ & $\begin{array}{l}\text { Reference to Article } 6 \text { of the } \\
\text { Convention (see above) }\end{array}$ & $\begin{array}{l}\text { "The Treaty sanctions not only breaches of specific Treaty provisions, such as Article 3.1, but also breaches of any rule of international law (Article 7.3). The Treaty thus covers } \\
\text { also a denial of justice under international law. }\end{array}$ \\
\hline
\end{tabular}




\begin{tabular}{|c|c|c|c|}
\hline $\begin{array}{l}\text { REFERENCE OF } \\
\text { DOCUMENT }\end{array}$ & $\begin{array}{l}\text { JURISDICTIONAL } \\
\text { BASIS }\end{array}$ & $\begin{array}{l}\text { ARTICLES OF THE AGREEMENT } \\
\text { CITED }\end{array}$ & RELEVANT EXTRACT \\
\hline $\begin{array}{l}\text { ARB } / 07 / 12 \text {, Decision on } \\
\text { Jurisdiction, } 11 \text { September } \\
2009 \text { (paras. 154-157) }\end{array}$ & & & $\begin{array}{l}\text { It has to be conceded that international law has no strict standards to assess whether court delays are a denial of justice. } \\
\text { As a matter of principle, the failure to render justice within a reasonable period of time may constitute a breach of international customary law [...] } \\
\text { Article } 6 \text { of the ECHR certainly covers the question to which extent lengthy court proceedings are a breach of the right to due process and to a fair and equitable trial. This } \\
\text { matter has been extensively subject of decisions from domestic courts and from the European Court of Human Rights. However, as Lebanon is not party to the ECHR and lies } \\
\text { outside the territorial scope of the ECHR, these decisions are not relevant in this case." }\end{array}$ \\
\hline $\begin{array}{l}\text { Azurix Corp. ve the } \\
\text { Argentine Republic, ICSID } \\
\text { Case No. ARB } / 01 / 12, \\
\text { Decision on the } \\
\text { Application for Annulment } \\
\text { of the Argentine Republic, } \\
\text { 1 September } 2009 \text { (para. } \\
\text { 128) }\end{array}$ & $\begin{array}{l}\text { Argentina- } \\
\text { United } \\
\text { BIT }\end{array}$ & $\begin{array}{l}\text { General reference to the } \\
\text { Convention as a whole and to } \\
\text { Article } 1 \text { of its Protocol No. } 1: \\
\text { "Every natural or legal person is } \\
\text { entitled to the peaceful } \\
\text { enjoyment of his possessions. No } \\
\text { one shall be deprived of his } \\
\text { possessions except in the public } \\
\text { interest and subject to the } \\
\text { conditions provided for by law } \\
\text { and by the general principles of } \\
\text { international law." }\end{array}$ & $\begin{array}{l}\text { "Argentina also has referred by analogy to the European Convention on Human Rights and NAFTA. As the extent of the protections afforded by an investment protection treaty } \\
\text { depends in each case on the specific terms of the treaty in question, the Committee regards comparison with differently-worded treaties as of limited utility, especially treaties } \\
\text { outside the field of investment protection. It is noted that the European Court of Human Rights has held that (subject to possible exceptions) a shareholder in a company does } \\
\text { not have standing to bring a claim for violation of the company's rights under Article } 1 \text { of Protocol No. } 1 \text { of the European Convention on Human Rights, and that the mere fact } \\
\text { that there has been a violation of the company's rights under Article } 1 \text { of Protocol No. 1, does not of itself mean that there has been a violation of the shareholders rights under } \\
\text { that provision. However, such an approach does not inform the situation where a law or a treaty might confer certain rights directly on a shareholder which would be violated } \\
\text { by an injury to the company, or answer the question whether the shareholder could have standing to bring a claim in that event." }\end{array}$ \\
\hline 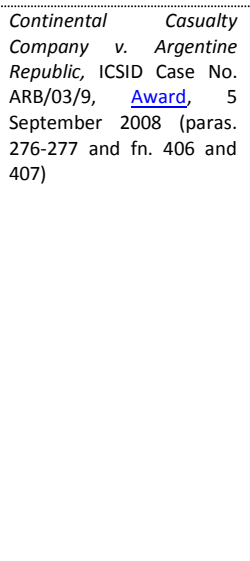 & $\begin{array}{l}\text { Argentina- } \\
\text { United } \\
\text { BIT }\end{array}$ & $\begin{array}{l}\text { Reference to Article } 1 \text { of Protocol } \\
\text { No. } 1 \text { (see above) }\end{array}$ & 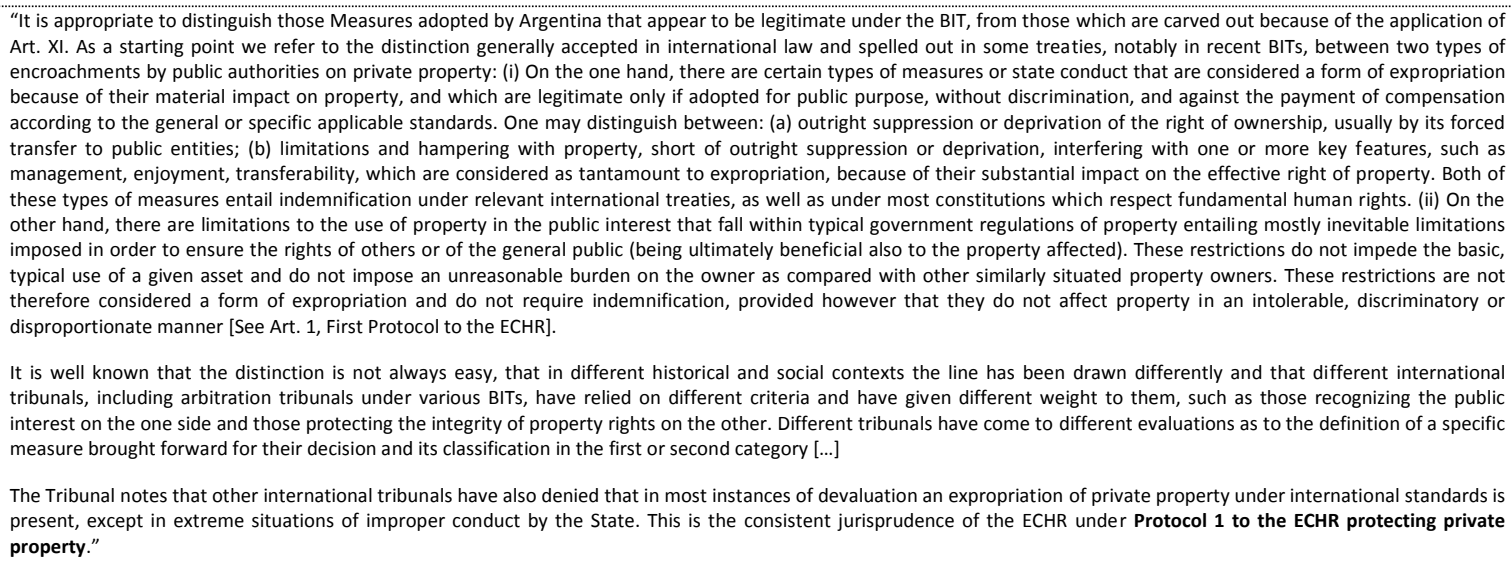 \\
\hline
\end{tabular}




\begin{tabular}{|c|c|c|c|}
\hline $\begin{array}{l}\text { REFERENCE OF } \\
\text { DOCUMENT }\end{array}$ & $\begin{array}{l}\text { JURISDICTIONAL } \\
\text { BASIS }\end{array}$ & $\begin{array}{l}\text { ARTICLES OF THE AGREEMENT } \\
\text { CITED }\end{array}$ & RELEVANT EXTRACT \\
\hline $\begin{array}{l}\text { Perenco Ecuador Limited } v \text {. } \\
\text { Republic of Ecuador and } \\
\text { Empresa Estatal Petróleos } \\
\text { del Ecuador, ICSID Case } \\
\text { No. ARB/08/6, Decision on } \\
\text { Provisional Measures, } 8 \\
\text { May } 2009 \text { (paras. 69-70) }\end{array}$ & $\begin{array}{l}\text { Ecuador-France } \\
\text { BIT }\end{array}$ & $\begin{array}{l}\text { General reference to the } \\
\text { Convention as a whole }\end{array}$ & 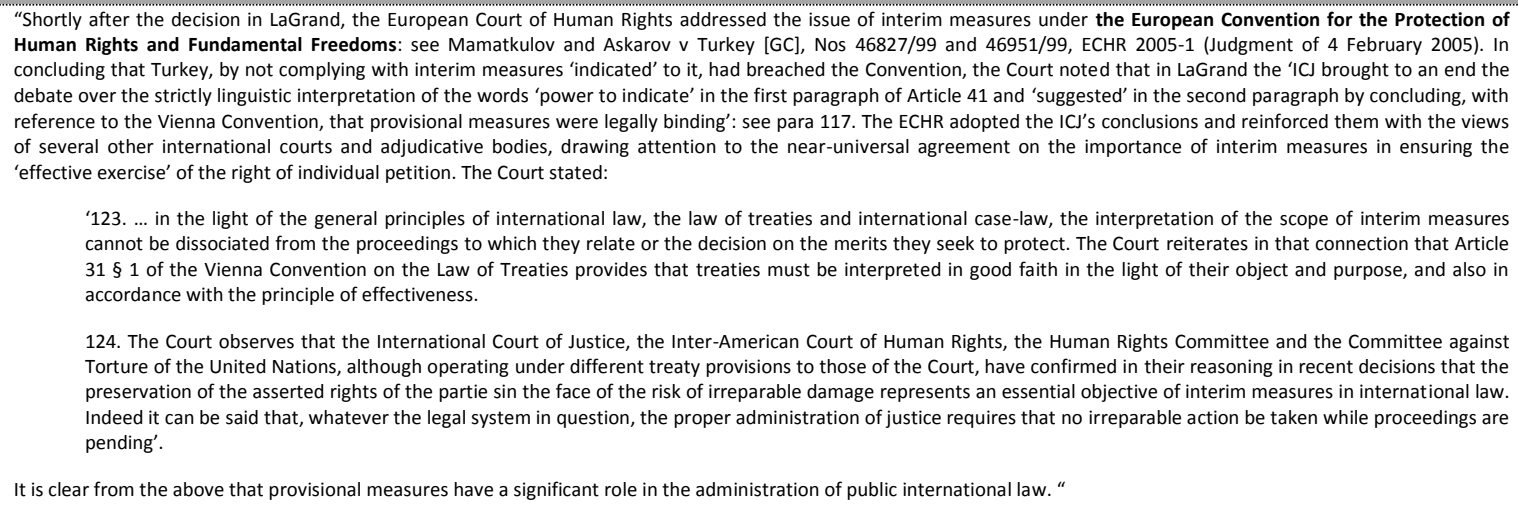 \\
\hline $\begin{array}{l}\text { Victor Pey Casado and } \\
\text { President Allende } \\
\text { Foundation v. Republic of } \\
\text { Chile, ICSID Case No. } \\
\text { ARB/98/2, Award, } 8 \text { May } \\
\text { 2008 (paras. 659-662) }\end{array}$ & Chile-Spain BIT & $\begin{array}{l}\text { Reference to Article } 6 \text { of the } \\
\text { Convention (see above) }\end{array}$ & 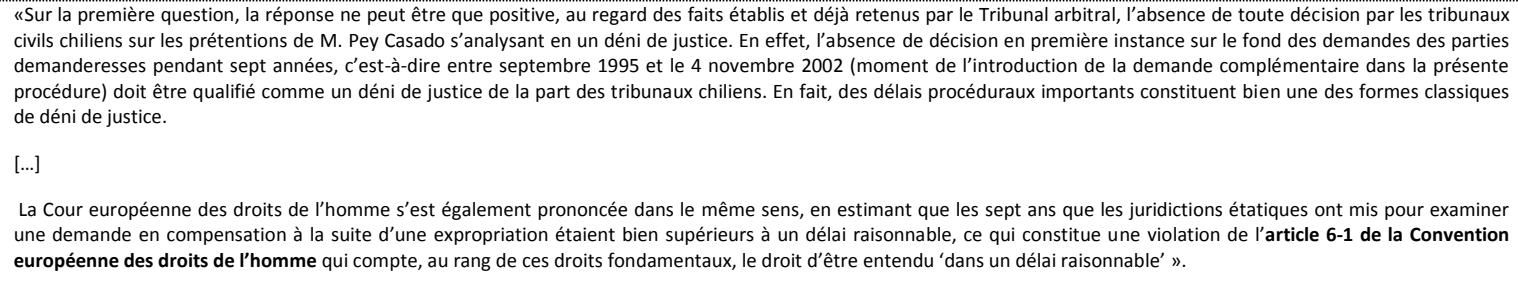 \\
\hline $\begin{array}{l}\text { Limited Liability Company } \\
\text { Amto V. Ukraine, } \\
\text { Arbitration No. 080/2005, } \\
\text { Final Award, } 26 \text { March } \\
2008 \text { (para. } 71 \text { ) }\end{array}$ & $\begin{array}{l}\text { Energy } \\
\text { Treaty }\end{array}$ & $\begin{array}{l}\text { General reference to the } \\
\text { Convention as a whole and to } \\
\text { Article } 1 \text { of Protocol No. } 1 \text { (see } \\
\text { above) }\end{array}$ & $\begin{array}{l}\text { "This is a case of an international tribunal and a supra-national court having concurrent jurisdiction over a dispute arising out of similar facts. However, the parties and the } \\
\text { causes of action are different in these two proceedings. With regard to the parties, EYUM-10 is not a party to the present arbitration and AMTO is not a party to the ECHR } \\
\text { proceedings. With respect to the causes of action, the present arbitration is based on alleged breaches of the ECT, while proceedings before the ECHR are based on Article 6(1) } \\
\text { of the European Convention and its Protocol No. 1, Article 1. These circumstances are sufficient to disqualify the Respondent's lis pendens objection." }\end{array}$ \\
\hline 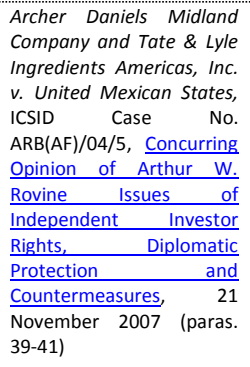 & NAFTA & $\begin{array}{l}\text { Reference to Article } 1 \text { of Protocol } \\
\text { No. } 1 \text { (see above) }\end{array}$ & $\begin{array}{l}\text { "Mention should also be made of human rights treaties which, of course, differ in significant ways from Chapter Eleven and BITs, but nevertheless are further examples of direct } \\
\text { grants of individual rights by treaty to be enforced against the States Parties to the treaty [...] } \\
\text { There are some respects in which a human rights treaty may be analogous to Chapter Eleven or to a BIT. Claimants point out, as an example, that Article } 1 \text { of Protocol } 1 \text { of the } \\
\text { European Convention on Human Rights protects both individuals and companies from an unlawful expropriation of property by a contracting government. A private party may } \\
\text { bring a claim against a breaching government before the European Court of Human Rights, challenging the expropriation. Governments may also challenge the actions of } \\
\text { another State Party to the European Convention. So there exists within the European Convention a dual system of government and private party enforcement, somewhat } \\
\text { similar to NAFTA." }\end{array}$ \\
\hline $\begin{array}{l}\text { Siemens A.G. V. Argentine } \\
\text { Republic, ICSID Case No. } \\
\text { ARB } 02 / 8, \quad \text { Award, } \quad 6 \\
\text { February 2007 (para. 354) }\end{array}$ & Germany BIT & $\begin{array}{l}\text { Reference to Article } 1 \text { of Protocol } \\
\text { No. } 1 \text { (see above) }\end{array}$ & 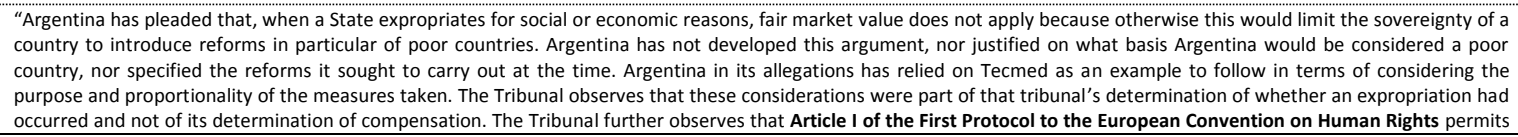 \\
\hline
\end{tabular}




\begin{tabular}{|c|c|c|c|}
\hline $\begin{array}{l}\text { REFERENCE OF } \\
\text { DOCUMENT }\end{array}$ & $\begin{array}{l}\text { JURISDICTIONAL } \\
\text { BASIS }\end{array}$ & $\begin{array}{l}\text { ARTICLES OF THE AGREEMENT } \\
\text { CITED }\end{array}$ & RELEVANT EXTRACT \\
\hline & & & a margin of appreciation not found in customary international law or the Treaty." \\
\hline $\begin{array}{l}\text { International Thunderbird } \\
\text { Gaming Corporation v. } \\
\text { United Mexican States, } \\
\text { UNCITAL, } \quad \text { Separate } \\
\text { Opinion, } 01 \text { December } \\
2005 \text { (para. 141) }\end{array}$ & NAFTA & $\begin{array}{l}\text { General reference to the } \\
\text { Convention as a whole }\end{array}$ & $\begin{array}{l}\text { "The judicial practice most comparable to treaty-based investor-sate arbitration is the judicial recourse available to individuals against states under the European Convention } \\
\text { on Human Rights; again, states have to defray their own legal representation expenditures, even if they prevail." }\end{array}$ \\
\hline $\begin{array}{l}\text { Mondev International Ltd. } \\
\text { v. United States of } \\
\text { America, ICSID Case No. } \\
\text { ARB(AF)/99/2, Award, } 11 \\
\text { October 2002 (paras. } 138, \\
144 \text { and 150) }\end{array}$ & NAFTA & $\begin{array}{l}\text { Reference to Article } 7 \text { of the } \\
\text { Convention: "No one shall be } \\
\text { held guilty of any criminal } \\
\text { offence on account of any act or } \\
\text { omission which did not } \\
\text { constitute a criminal offence } \\
\text { under national or international } \\
\text { law at the time when it was } \\
\text { committed. Nor shall a heavier } \\
\text { penalty be imposed than the one } \\
\text { that was applicable at the time } \\
\text { the criminal offence was } \\
\text { committed [...]" }\end{array}$ & 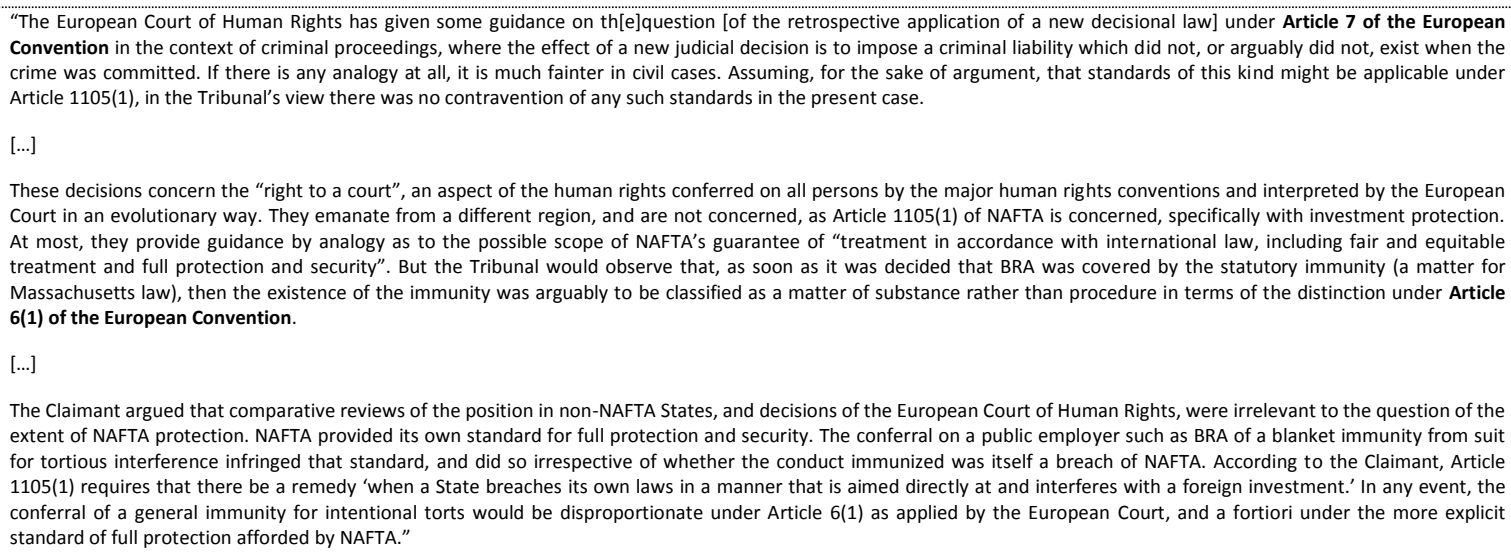 \\
\hline 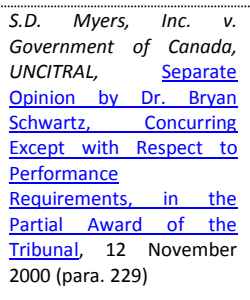 & NAFTA & $\begin{array}{l}\text { General reference to the } \\
\text { Convention as a whole }\end{array}$ & $\begin{array}{l}\text { "In the last fifty years, international law has increasingly recognized the right of individuals to complain about mistreatment by their own governments. Under some } \\
\text { arrangements, like the European Convention of Human Rights or the Optional Protocol to the International Covenant on Civil and Political Rights, individuals have been given } \\
\text { standing to make claims against their own governments. In many situations, however, nationals remain without international remedies in the face of domestic injustice." }\end{array}$ \\
\hline \multicolumn{4}{|r|}{ INDIGENOUS AND TRIBAL PEOPLES CONVENTION NO. 169 (1989) } \\
\hline $\begin{array}{l}\text { Grand River Enterprises Six } \\
\text { Nations, Ltd., et al. } \quad \text {. } \\
\text { United States of America, } \\
\text { UNCITRAL, Award, } 12 \\
\text { January } 2011 \text { (para. 59) }\end{array}$ & NAFTA & $\begin{array}{l}\text { General reference to the } \\
\text { Convention as a whole }\end{array}$ & $\begin{array}{l}\text { "Pursuant to NAFTA Article 1128, Canada submitted a statement of its views regarding the interpretetation of NAFTA's Article } 1105 \text { on January } 19,2009 \text {. Canada's submission } \\
\text { stated, inter alia, that (1) pursuant to the Free Trade Commissions July } 31,2001 \text { Notes of Interpretation, a violation of the Jay Treaty as alleged by the Claimants does not } \\
\text { establish a violation of NAFTA A Atricle } 1105(1) \text {; and (2) IL Convention } 169 \text { and the U.N. Declaration on the Rights of Indigenous Peoples do not constitute customary } \\
\text { international law, and so do not fall within the ambit of Article } 1105(1) \text {." }\end{array}$ \\
\hline \multicolumn{4}{|r|}{ INTER-AMERICAN CONVENTION ON HUMAN RIGHTS (1969) } \\
\hline $\begin{array}{l}\text { El Paso Energy } \\
\text { International Company v. } \\
\text { Argentine Republic, ICSID } \\
\text { Case No. ARB/03/15, } \\
\text { Award, } 31 \text { October } 2011\end{array}$ & $\begin{array}{l}\text { Argentina-US } \\
\text { BIT }\end{array}$ & $\begin{array}{l}\text { Reference to Article 27: "(1) In } \\
\text { time of war, public danger, or } \\
\text { other emergency that threatens } \\
\text { the independence or security of a } \\
\text { State Party, it may take measures }\end{array}$ & $\begin{array}{l}\text { "Treaty provisions allowing for exceptions to the rights guaranteed in the same treaty must be attributed the ordinary meaning resulting from their text, without reading self- } \\
\text { judging clauses into them, especially when the treaty contains compromissory clauses, as is the case here. This clearly results from the case-law and from international practice. } \\
{[\ldots . .]}\end{array}$ \\
\hline
\end{tabular}




\begin{tabular}{|c|c|c|c|}
\hline $\begin{array}{l}\text { REFERENCE OF } \\
\text { DOCUMENT }\end{array}$ & $\begin{array}{l}\text { JURISDICTIONAL } \\
\text { BASIS }\end{array}$ & $\begin{array}{l}\text { ARTICLES OF THE AGREEMENT } \\
\text { CITED }\end{array}$ & RELEVANT EXTRACT \\
\hline (paras. 592-598) & & $\begin{array}{l}\text { derogating from its obligations } \\
\text { under the present Convention to } \\
\text { the extent and for the period of } \\
\text { time strictly required by the } \\
\text { exigencies of the situation, } \\
\text { provided that such measures are } \\
\text { not inconsistent with its other } \\
\text { obligations under international } \\
\text { law and do not involve } \\
\text { discrimination on the ground of } \\
\text { race, color, sex, language, } \\
\text { religion, or social origin [....". }\end{array}$ & $\begin{array}{l}\text { Article } 15 \text { of the } 1950 \text { European Convention on Human Rights allows States Parties, in time of war or other public emergency threatening the life of the nation, to derogate from } \\
\text { their obligations under the Convention - except regarding Articles } 2,3,4(1) \text { and } 7-\text { to the extent strictly required by the exigencies of the situation, provided that such } \\
\text { derogations are not inconsistent with the Parties' other obligations under international law. A similar clause can be found in Article } 27 \text { of the } 1969 \text { American Human Rights } \\
\text { Convention. The case-law of the European Court of Human Rights shows that these provisions, despite their being emergency clauses, are far from being self-judging. In } \\
\text { concrete cases brought before the court and involving derogations formulated on the basis of those provisions, it is the European Court which determines whether they meet } \\
\text { the conditions provided for in Article 15." }\end{array}$ \\
\hline $\begin{array}{l}\text { Sempra } \\
\text { International v. Argergy } \\
\text { Republic, ICSID Case No. } \\
\text { ARB/02/16, } \quad \text { Award, } 28 \\
\text { September } 2007 \text { (paras. } \\
\text { 331-332) }\end{array}$ & $\begin{array}{l}\text { Argentina- } \\
\text { United States } \\
\text { BIT }\end{array}$ & $\begin{array}{l}\text { General reference to the } \\
\text { Convention as a whole }\end{array}$ & 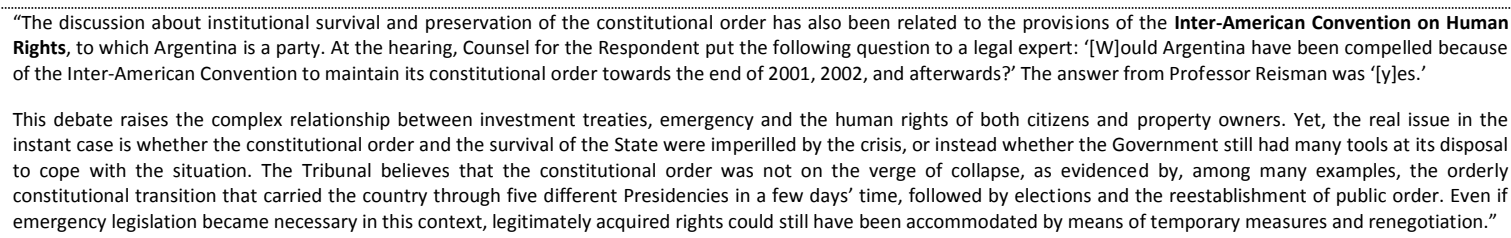 \\
\hline \multicolumn{4}{|r|}{ ITIONAL CONVENTION ON THE ELIMINATION OF ALL FORMS OF RACIAL DISCRIMINATION (1965) } \\
\hline $\begin{array}{l}\text { Philip Morris Brand Sàrl } \\
\text { (Switzerland), Philip Morris } \\
\text { Products S.A. (Switzerland) } \\
\text { and Abal Hermanos S.A. } \\
\text { (Uruguay) V. Oriental } \\
\text { Republic of Uruguay, ISSID } \\
\text { Case No. ARB I/107, } \\
\text { Decision on Jurisdiction, 2 } \\
\text { July 2013 (paras. 141-142) }\end{array}$ & $\begin{array}{l}\text { Uruguay- } \\
\text { Switzerland BIT }\end{array}$ & $\begin{array}{l}\text { Reference to a decision rendered } \\
\text { in application of the Convention }\end{array}$ & $\begin{array}{l}\text { "The position in international law generally is stated by the ICJ. In Georgia v. Russia, the Court explained the legal character of procedural preconditions as follows: } \\
\text { 'To the extent that the procedural requirements of [a dispute settlement clause] may be conditions, they must be conditions precedent to the seisin of the court even when the } \\
\text { term is not qualified by a temporal element' 'referring to Case Concerning Application of the International Convention on the Elimination of all Forms of Racial Discrimination } \\
\text { (Georgia v. Russian Federation), Judgment on Preliminary Objections, } 1 \text { Aprii 2011, para. 130] } \\
\text { [...] } \\
\text { In the present case, the Tribunal does not consider it necessary to characterize the 18-month domestic litigation requirement as pertaining to jurisdiction or to admissibility. } \\
\text { Even if that requirement were considered as pertaining to admissibility, its compulsory character would be evident. This conclusion is confirmed by the object and purpose of } \\
\text { the requirement in question which is aimed at offering the host State the opportunity to redress the violatations of the BIT allleged by the investor. The objective pursued by the } \\
\text { Respondent when negotiating the domestic litigation requirement was made clear during the Uruguavan Parliamentary debate leading to the approval of the BIT. The Claimants } \\
\text { do not dispute that this was the Respondent's objective when providing for this requirement in the BIT." }\end{array}$ \\
\hline 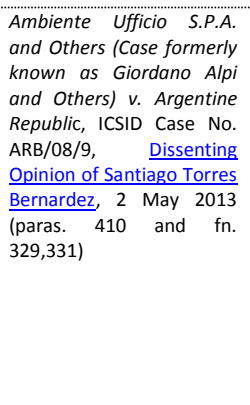 & $\begin{array}{l}\text { Argentina-Italy } \\
\text { BIT }\end{array}$ & $\begin{array}{l}\text { Reference to Article 22: "Any } \\
\text { dispute between two or more } \\
\text { States Parties with respect to the } \\
\text { interpretation or application of } \\
\text { this Convention, which is not } \\
\text { settled by negotiation or by the } \\
\text { procedures expressly provided } \\
\text { for in this Convention, shall, at } \\
\text { the request of any of the parties } \\
\text { to the dispute, be referred to the } \\
\text { lnternational Court of Justice for } \\
\text { decision, unless the disputants } \\
\text { agree to another mode of } \\
\text { settlement." }\end{array}$ & $\begin{array}{l}\text { "The fact that Article } 22 \text { of the Convention on the Elimination of All Forms of Racial Discrimination (CERD) is not drafted in mandatory terms did not prevent the Court to } \\
\text { dismiss the case for non-compliance by claimant of the two alternative preconditions to judicial settlement set out in the said Article 22, namely negotiations or referral to } \\
\text { procedures expressly provided for in CERD. } \\
\text { [...] } \\
\text { I conclude, therefore, that the extent of consent to international arbitration contained in the Argentine Republic's offer of the BIT does not cover the international arbitration } \\
\text { proceeding instituted by Claimants in the instant case. This conclusion of mine is based upon the text of Article } 8(1) \text { of the BIT in the context of paragraphs (1)-(3) of the Article } \\
\text { as a whole. It is furthermore conformed to the established jurisprudence of the ICJ on the matter, as well as to a number of arbitral decisions in ICSID case-law. As declared by } \\
\text { the IIJ in its Judgment in the Case concerning Application of the CERD (Georgia v. Russian Federation): 'Manifiestly, in the absence of evidence of a genuine attempt to to } \\
\text { negotiate, the precondition of negotiation is not met. However, where negotiations are attempted or have commenced the jurisprudence of this Court and of the Permanent } \\
\text { Court of International Justice clearly reveals that the precondition of negotiation is met only when there has been a failure of negotiations, or when negotiations have become } \\
\text { futile or deadlocked'. } \\
\text { The ICJ dismissed the above case by lack of jurisdiction because Georgia was unable to prove that in fact it sought to commence good faith negotiation or the other settlement } \\
\text { method provided for in Article } 22 \text { of CERD as preconditions for the seisin of the Court." }\end{array}$ \\
\hline $\begin{array}{l}\text { Tulip Real Estate and } \\
\text { Development Netherlands } \\
\text { B.V. v. Republic of Turkey, }\end{array}$ & $\begin{array}{l}\text { Netherlands- } \\
\text { Turkey BIT }\end{array}$ & $\begin{array}{l}\text { Reference to a decision rendered } \\
\text { in application of the Convention }\end{array}$ & $\begin{array}{l}\text { "In Case Concerning Application of the International Convention on the Elimination of All Forms of Racial Discrimination (Georgia v Russian Federation) the ICJ addressed the } \\
\text { function of a 'compromissory' provision of this sort in terms : }\end{array}$ \\
\hline
\end{tabular}




\begin{tabular}{|c|c|c|c|}
\hline $\begin{array}{l}\text { REFERENCE OF } \\
\text { DOCUMENT }\end{array}$ & $\begin{array}{c}\text { JURISDICTIONAL } \\
\text { BASIS }\end{array}$ & $\begin{array}{l}\text { ARTICLES OF THE AGREEMENT } \\
\text { CITED }\end{array}$ & RELEVANT EXTRACT \\
\hline $\begin{array}{l}\text { ICSID Case No. ARB/11/28, } \\
\text { Decision on } \quad \text { Bifurcated } \\
\text { Jurisdictional Issue, } 5 \\
\text { March 2013 (paras. 61-62 } \\
\text { and 84-87) }\end{array}$ & & & $\begin{array}{l}\text { '[IIt is not unusual in compromissory clauses conferring jurisdiction on the Court and other international jurisdictions to refer to resort to negotiations. Such resort fulfills } \\
\text { three distinct functions. In the first place, it gives notice to the respondent State that a dispute exists and delimits the scope of the dispute and its subject-matter.. In the } \\
\text { second place, it encourages the Parties to attempt to settle their dispute by mutual agreement, thus avoiding recourse to binding third-party adjudication. In the third } \\
\text { place, prior resort to negotiations or other methods of peaceful dispute settlement performs an important function in indicating the limit of consent given by States.' } \\
\text { The Tribunal adds a fourth aspect, namely, that it sees that such a requirement also fulfils the policy function of conferring upon the State Party an opportunity to address a } \\
\text { potential claimant's complaint before it becomes a respondent in an international investment dispute. } \\
\text { [...] } \\
\text { The second requirement in Article } 8(2) \text { is that the parties seek to engage in consultations and negotiations in good faith. Respondent relies on decisions by the ICJ in Armed } \\
\text { Activities (DRC v. Rwanda) case and Case Concerning Application of the International Convention on the Elimination of All Forms of Racial Discrimination (Georgia v Russian } \\
\text { Federation) to emphasize that negotiations must be referable to the treaty dispute. In the latter case, the ICJ said: } \\
\text {... to meet the precondition of negotiation in the compromissory clause of a treaty, these negotiations must relate to the subject-matter of the treaty containing the } \\
\text { compromissory clause. In other words, the subject-matter of the negotiations must relate to the subject-matter of the dispute which, in turn, must concern the } \\
\text { substantive obligations contained in the treaty in question. } \\
\text { [...] } \\
\text { The Tribunal agrees with the above statement of the ICJ and considers that the subject matter of the consultations and negotiations to be engaged must relate to the subject } \\
\text { matter of the investment dispute brought before this Tribunal under the BIT. It is not necessary for the parties to make express reference to the treaty in their consultations or } \\
\text { negotiations." }\end{array}$ \\
\hline $\begin{array}{l}\text { Ambiente Ufficio S.P.A.A } \\
\text { and Others (Case formerly } \\
\text { known as Giordano Alpi } \\
\text { and Others) v. Argentine } \\
\text { Republic, ICSID Case No. } \\
\text { ARB/80/9, Decision on on } \\
\text { Jurisdiction and } \\
\text { Admissibility, } 8 \text { andruary } \\
2013 \text { (para. 570, fn. 288) }\end{array}$ & $\begin{array}{l}\text { Argentina-Italy } \\
\text { BIT }\end{array}$ & $\begin{array}{l}\text { Reference to Article 22: "Any } \\
\text { dispute between two or more } \\
\text { States Parties with respect to the } \\
\text { interpretation or application of } \\
\text { this Convention, which is not } \\
\text { settled by negotiation or by the } \\
\text { procedures expressly provided } \\
\text { for in this Convention, shall, at } \\
\text { the request of any of the partitis } \\
\text { to the dispute, be referred to the } \\
\text { International Court of Justice for } \\
\text { decision, unless the disputants } \\
\text { agree to another mode of } \\
\text { settlement." } \\
\text { The tribunal also refers to article } \\
29 \text { of the Convention on the } \\
\text { Elimination of all Forms of } \\
\text { Discrimination Against Women }\end{array}$ & $\begin{array}{l}\text { "In Application of the International Convention on the Elimination of all Forms of Racial Discrimination (Georgia v. Russia), Preliminary objections, Judgment, } 1 \text { April } 2011 \text {, } \\
\text { para. } 141, \text { the negotiation requirement in Art. } 22 \text { of the Convention was considered a precondition to be fulfilled before the seisin of the Court, i.e. a precondition to the } \\
\text { exercise of the Court's jurisdiction. } \\
\text { [...] } \\
\text { Both Parties have drawn the Tribunal's attention to numerous authorities and cases in which legal issues which they deemed comparable to those in the present dispute were } \\
\text { at stake. In particular, the International Court of Justice, relying on its case-law on the matter, recently qualified negotiation requirements stemming from Art. } 29 \text { of the } \\
\text { Convention on the Elimination of all Forms of Discrimination against Women as affecting its jurisdiction. In contrast, the Tribunal in the Abaclat case - which had the same BIT } \\
\text { before it as the present Tribunal - concluded that Art. } 8(1)-(3) \text { of the Argentina-ltaly BIT were requirements of admissibility rather than jurisdiction. } \\
\text { Further examples could be added at will. The major conclusion to be drawn for them, however, is that there has not been a consistent approach on these matters by investment } \\
\text { treaty tribunals, let alone in international law more generally." }\end{array}$ \\
\hline $\begin{array}{l}\text { ICS Inspection and Control } \\
\text { Services Limited (United } \\
\text { Kingdom) v. Argentine } \\
\text { Republic, PCA Case No. } \\
2010-9, \text { Award on } \\
\text { Jurisdiction, } 10 \text { February } \\
2012 \text { (para. 250) }\end{array}$ & $\begin{array}{l}\text { Argentina- } \\
\text { United Kingdom } \\
\text { BIT }\end{array}$ & $\begin{array}{l}\text { General reference to the } \\
\text { Convention as a whole }\end{array}$ & $\begin{array}{l}\text { "Moreover, the trend in public international law has clearly favoured the strict application of procedural prerequisites. For example, in the recent case of Georgia v. Russia } \\
\text { before the ICJ, despite the absence of mandatory language, a majority of the ICJ found that the phrase 'dispute... which is not settled by negotiation or by the procedures } \\
\text { expressly provided for in this Convention' established a precondition to resort to negotiations or to the procedures expressly provided for under the International Convention } \\
\text { on the Elimination of All Forms of Racial Discrimination (CERD), prior to the seisin of the IJ." }\end{array}$ \\
\hline $\begin{array}{l}\text { Daimler Financial Services } \\
\text { AG v. Argentine Republic, } \\
\text { ICSID Case No. ARB/05/1, } \\
\text { Award, } 22 \text { August } 2012 \\
\text { (para. } 194 \text { and fn. 348) }\end{array}$ & $\begin{array}{l}\text { Argentina- } \\
\text { Germany BIT }\end{array}$ & $\begin{array}{l}\text { Reference to a decision rendered } \\
\text { in application of the Convention }\end{array}$ & $\begin{array}{l}\text { "Since the 18-month domestic courts provision constitutes a treaty-based pre-condition to the Host State's consent to arbitrate, it cannot be bypassed or otherwise waived by } \\
\text { the Tribunal as a mere 'procedural' or 'admissibility-related' matter [referring to Case Concerning Application of the International Convention on the Elimination of All Forms } \\
\text { of Racial Discrimination (Georgia v. Russian Federation), Preliminary Objections (Decision of } 1 \text { April } 2011),[\ldots] \text { ( Ifinding that the relevant treaty's requirement of good faith } \\
\text { negotiations between the parties constituted a procedural condition for the seisin of the Court and further finding that the Court had no jurisdiction because this precondition } \\
\text { had not been met)]." }\end{array}$ \\
\hline HOCHTIEF & Argentina- & Reference to a decision rendered & rior recourse' provision are jurisdictional in nature] has been reaffirmed as recently as April of 2011 , when the ICJ found that the preconditions established in \\
\hline
\end{tabular}




\begin{tabular}{|c|c|c|c|}
\hline $\begin{array}{l}\text { REFERENCE OF } \\
\text { DOCUMENT }\end{array}$ & $\begin{array}{l}\text { JURISDICTIONAL } \\
\text { BASIS }\end{array}$ & $\begin{array}{l}\text { ARTICLES OF THE AGREEMENT } \\
\text { CITED }\end{array}$ & RELEVANT EXTRACT \\
\hline $\begin{array}{l}\text { Aktiengesellschaft } \\
\text { Argentine Republic, ICSID } \\
\text { Case No. ARB/07/31, } \\
\text { Separate and Dissenting } \\
\text { Opinion of J. Christopher } \\
\text { Thomas, Q.C., } 24 \text { October } \\
2011 \text { (para. } 77 \text { and related } \\
\text { fn. 48) }\end{array}$ & Germany BIT & in application of the Convention & $\begin{array}{l}\text { Article } 22 \text { of the International Convention on the Elimination of All Forms of Racial Discrimination 'stablish preconditions before the seisin of the Court' (Article } 22 \text { of the } \\
\text { Convention states: 'Any dispute between two or more States Parties with respect to the interpretation or application of this Convention, which is not settled by negotiation or } \\
\text { by the procedures expressly provided for in this Convention, shall, at the request of any of the parties to the dispute, be referred to the International Court of Justice for } \\
\text { decision, unless the disputants agree to another mode of settlement.' Case concerning Application of the International Convention on the Elimination of All Forms of Racial } \\
\text { Discrimination (Georgia v. Russian Federation), Judgment of } 1 \text { April 2011]." }\end{array}$ \\
\hline $\begin{array}{l}\text { Impregilo S.P.A. } \\
\text { Argentine Republic, ICSID } \\
\text { Case No. AR/DT/17, } \\
\text { Concurring and Dissenting } \\
\text { Opinion of Professor } \\
\text { Brigitte Stern, } 21 \text { June } \\
2011 \text { (paras. } 82-83 \text { and fn. } \\
54 \text { ) }\end{array}$ & $\begin{array}{l}\text { Argentina-Italy } \\
\text { BIT }\end{array}$ & $\begin{array}{l}\text { Reference to a decision rendered } \\
\text { in application of the Convention }\end{array}$ & $\begin{array}{l}\text { "Are all conditions shaping the State's consent to be treated in the same manner or is there a distinction to be made between conditions of admissibility and conditions of } \\
\text { jurisdiction? } \\
\text { A delicate question needs however to be raised here, i.e. whether a distinction should be made between the different conditions shaping the State's consent to international } \\
\text { arbitration. This raises the issue of a possible distinction between conditions of admissibility and conditions of jurisdiction. } \\
\text { There appears to be no legal reason to treat differently these two types of requirements that condition the State's consent [This has been confirmed less than a month ago by by } \\
\text { the ICJ in the case concerning Application of the International Convention on the Elimination of All Forms of Racial Discrimination (Georgia v. Russian Federation), Judgment of } \\
1 \text { April } 2011 \text {. The Court had to interpret Article } 22 \text { of the International Convention on the Elimination of All Forms of Racial Discrimination ('CERD') of } 21 \text { December } 1965 \text {, which } \\
\text { reads : 'Any dispute between two or more States Partites with respect to the interpretation or application of this Convention, which is not settled by negotiation or by the } \\
\text { procedures expressly provided for in this Convention, shall, at the request of any of the parties to the dispute, be referred to the International Court of Justice for decision, } \\
\text { unless the disputants agree to another mode of settlement.' The Court considered that the terms of Article } 22 \text { 'establish preconditions before the seisin of the Court.']". }\end{array}$ \\
\hline \multicolumn{4}{|r|}{ INTERNATIONAL COVENANT ON CIVIL AND POLITICAL RIGHTS (1966) } \\
\hline 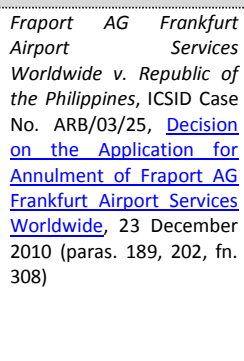 & $\begin{array}{l}\text { Germany- } \\
\text { Philippines BIT }\end{array}$ & $\begin{array}{l}\text { General reference to the } \\
\text { Covenant as a whole }\end{array}$ & 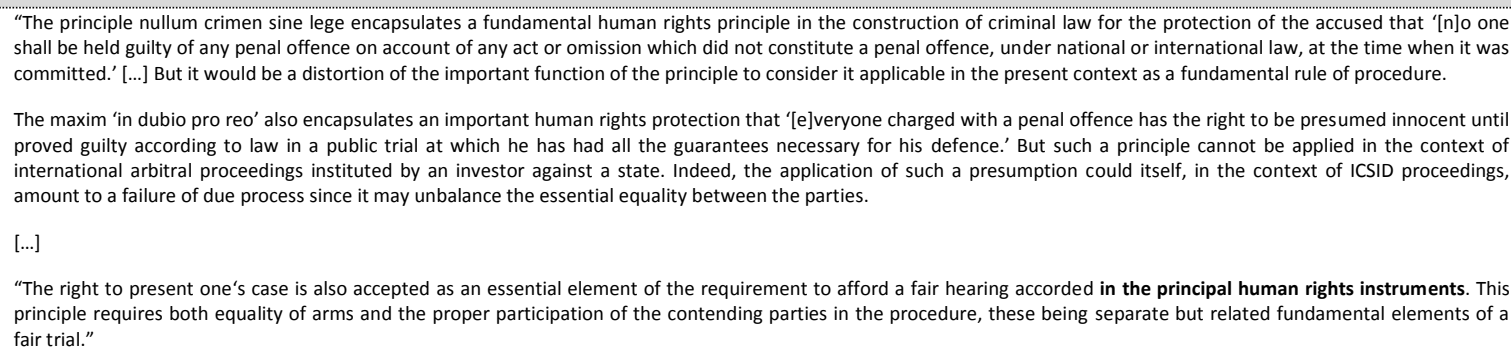 \\
\hline $\begin{array}{l}\text { The Rompetrol Group N.V. } \\
\text { v. Romania, ICSI Case No. } \\
\text { ARB/06/3, Decision of the } \\
\text { Tribunal on the } \\
\text { Participation of a Counsel, } \\
14 \text { January } 2010 \text { (paras. } \\
14-20 \text { and related fn. } 7 \text { ) }\end{array}$ & $\begin{array}{l}\text { Netherlands- } \\
\text { Romania BIT }\end{array}$ & $\begin{array}{l}\text { Reference to Article 14: (1) "All } \\
\text { persons shall be equal before the } \\
\text { courts and tribunals. In the } \\
\text { determination of any criminal } \\
\text { charge against him, or of his } \\
\text { rights and obligations in a suit at } \\
\text { law, everyone shall be entitled to } \\
\text { a fair and public hearing by a } \\
\text { competent, independent and } \\
\text { impartial tribunal established by } \\
\text { law. The press and the public } \\
\text { may be excluded from all or part } \\
\text { of a trial for reasons of morals, } \\
\text { public order (ordre public) or } \\
\text { national security in a democratic } \\
\text { society, or when the interest of } \\
\text { the private lives of the parties so } \\
\text { requires, or to the extent tstrictly } \\
\text { necessary in the opinion of the } \\
\text { court in special circumstances }\end{array}$ & 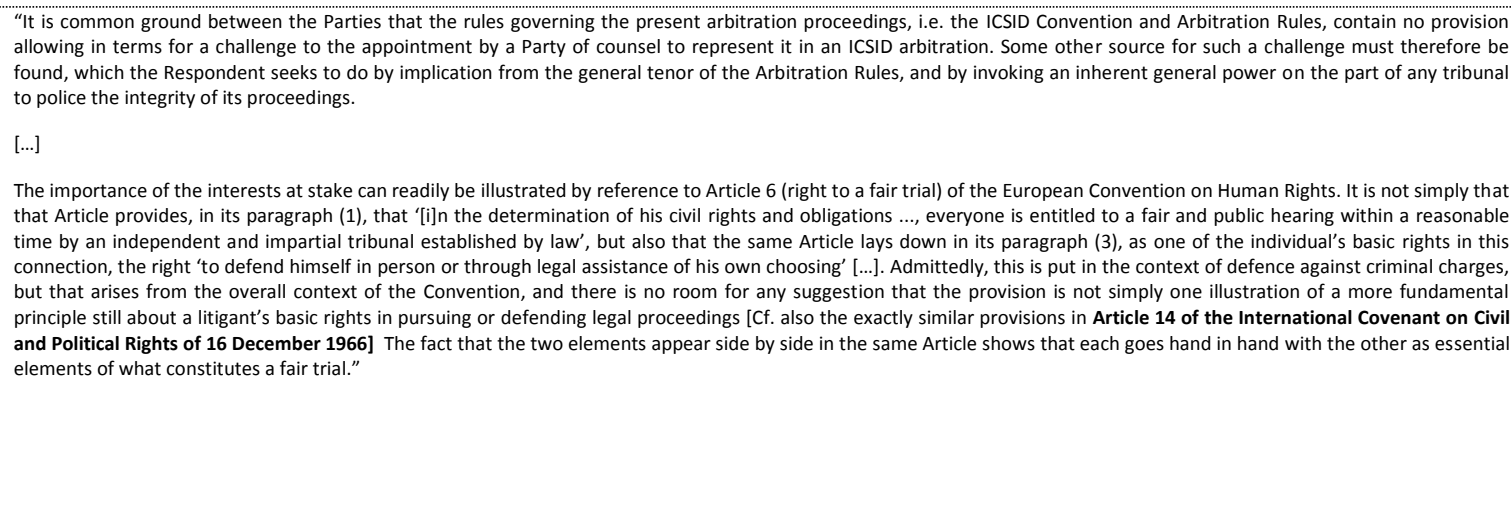 \\
\hline
\end{tabular}




\begin{tabular}{|c|c|c|c|}
\hline $\begin{array}{l}\text { REFERENCE OF } \\
\text { DOCUMENT }\end{array}$ & $\begin{array}{l}\text { JURISDICTIONAL } \\
\text { BASIS }\end{array}$ & $\begin{array}{c}\text { ARTICLES OF THE AGREEMENT } \\
\text { CITED }\end{array}$ & RELEVANT EXTRACT \\
\hline & & $\begin{array}{l}\text { where publicity would prejudice } \\
\text { the interests of justice; but any } \\
\text { judgement rendered in a criminal } \\
\text { case or in a suit at law shall be } \\
\text { made public except where the } \\
\text { interest of juvenile persons } \\
\text { otherwise requires or the } \\
\text { proceedings concern matrimonial } \\
\text { disputes or the guardianship of } \\
\text { children [...]". }\end{array}$ & \\
\hline $\begin{array}{l}\text { Toto Costruzioni Generali } \\
\text { S.p.A. v. Republic of } \\
\text { Lebanon, ICSID Case No. } \\
\text { ARB/O07/12, Decision on } \\
\text { Jurisdiction, } 11 \text { September } \\
2009 \text { (paras. 158-160) }\end{array}$ & $\begin{array}{l}\text { Italy-Lebanon } \\
\text { BIT }\end{array}$ & $\begin{array}{l}\text { Reference to Article } 14 \text { of the } \\
\text { Covenant (see above) and to its } \\
\text { Optional Protocol }\end{array}$ & $\begin{array}{l}\text { "The Treaty sanctions not only breaches of specific Treaty provisions, such as Article 3.1, but also breaches of any rule of international law (Article } 7.3 \text { ). The Treaty thus covers } \\
\text { also a denial of justice under international law. } \\
\text { It has to be conceded that international law has no strict standards to assess whether court delays are a denial of justice. } \\
\text { As a matter of principle, the failure to render justice within a reasonable period of time may constitute a breach of international customary law [...] } \\
\text { On the other hand, Lebanon is a party to the ICCPR, Article } 14.1 \text { which requires the right to a fair hearing: 'All persons shall be equal before the courts and tribunals. In the } \\
\text { determination of... his rights and obligations in a suit at law, everyone shall be entitled to a fair and public hearing by a competent, independent and impartial tribunal } \\
\text { established by law ...' } \\
\text { The right to a fair hearing entails a number of requirements, including the requirement that the procedure before the national tribunals be conducted expeditiously. } \\
\text { Under the Optional Protocol to the ICCPR, a State may accept that individual persons file a complaint against the State before the ICCPR Commission, which then gives its } \\
\text { opinion. However, Lebanon has not ratified this Protocol and thus cannot be summoned before the Commission. Nevertheless, the decisions of the Commission are relevant to } \\
\text { interpret the scope of Article } 14 \text { of the ICCPR. } \\
\text { To assess whether court delays are in breach of the requirement of a fair hearing, the ICCPR Commission takes into account the complexity of the matter, whether the } \\
\text { Claimants availed themselves of the possibilities of accelerating the proceedings, and whether the Claimants suffered from the delay. The ICCPR commission thus decided that a } \\
\text { two-and-a-half-year delay in the proceedings to annul an administrative order was acceptable. Likewise, a two-year period to obtain a judgment from an administrative tribunal } \\
\text { against a dismissal was equally acceptable. On the other hand, a delay of seven years to obtain a judgment for someone who asked to be reinstated in his position and an } \\
\text { additional delay of two-and-a-half years to get this judgment implemented was considered unacceptable. Likewise, eleven years of proceedings to obtain a final judgment } \\
\text { regarding custody of and access to the claimant's children was unreasonable." }\end{array}$ \\
\hline 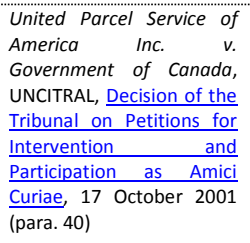 & NAFTA & $\begin{array}{l}\text { Reference to Article } 14 \text { of the } \\
\text { Covenant (see above) }\end{array}$ & $\begin{array}{l}\text { "We do not consider that the broader international law arguments assist the Petitioners. As they indeed acknowledge, international law and practice and related national law } \\
\text { and practice have either ignored or given very low priority to third party intervention [...]. Of the treaty provisions they cite, the one which is nearest to being applicable - article } \\
14 \text { of the International Covenant on civi and Political Rights - is about persons whose rights and obligations in a suit at law are being determined by a court or tribunal. That is } \\
\text { not the present case. The Petitioners' rights and obligations are not engaged in that way or indeed at all." }\end{array}$ \\
\hline 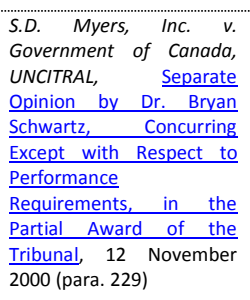 & NAFTA & $\begin{array}{l}\text { General reference to the } \\
\text { Covenant as a whole and to its } \\
\text { optional protocol }\end{array}$ & $\begin{array}{l}\text { "In the last fifty years, international law has increasingly recognized the right of individuals to complain about mistreatment by their own governments. Under some } \\
\text { arrangements, like the European Convention of Human Rights or the Optional Protocol to the International Covenant on Civil and Political Rights, individuals have been given } \\
\text { standing to make claims against their own governments. In many situations, however, nationals remain without international remedies in the face of domestic injustice." }\end{array}$ \\
\hline
\end{tabular}




\begin{tabular}{|c|c|c|c|}
\hline $\begin{array}{l}\text { REFERENCE OF } \\
\text { DOCUMENT }\end{array}$ & $\begin{array}{l}\text { JURISDICTIONAL } \\
\text { BASIS }\end{array}$ & $\begin{array}{l}\text { ARTICLES OF THE AGREEMENT } \\
\text { CITED }\end{array}$ & RELEVANT EXTRACT \\
\hline 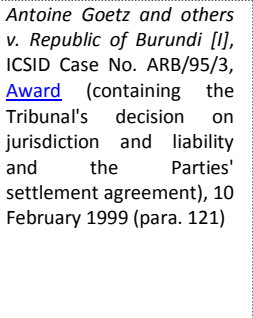 & $\begin{array}{l}\text { Belgium- } \\
\text { Luxembourg- } \\
\text { Burundi BIT }\end{array}$ & $\begin{array}{l}\text { Reference to Article 2: (2) "The } \\
\text { States Parties to the present } \\
\text { Covenant undertake to } \\
\text { guarantee that the rights } \\
\text { enunciated in the present } \\
\text { Covenant will be exercised } \\
\text { without discrimination of any } \\
\text { kind as to race, colour, sex, } \\
\text { language, religion, political or } \\
\text { other opinion, national or social } \\
\text { origin, property, birth or other } \\
\text { status." }\end{array}$ & 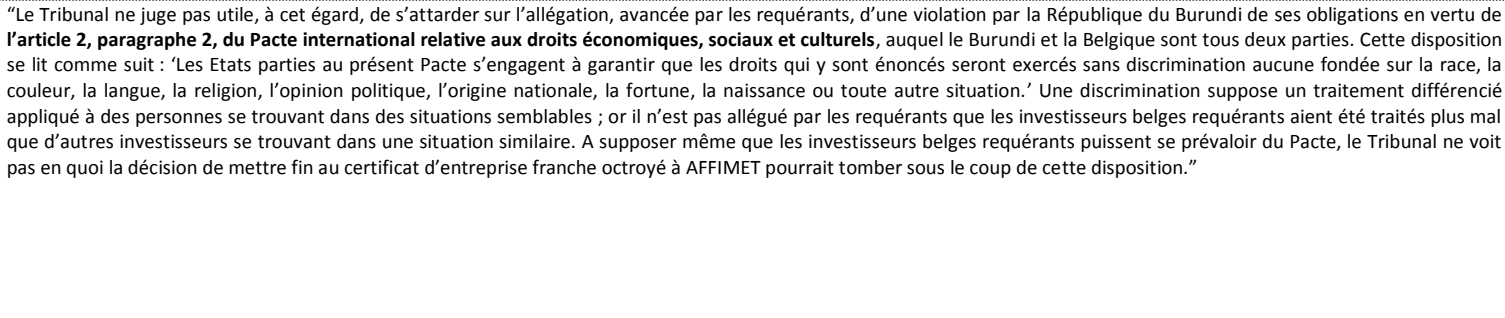 \\
\hline \multicolumn{4}{|c|}{ RESOLUTION ADOPTED BY THE GENERAL ASSEMBLY: $61 / 295$ UNITED NATIONS DECLARATION ON THE RIGHTS OF INDIGENOUS PEOPLES (2007) } \\
\hline $\begin{array}{l}\text { Grand River Enterprises Six } \\
\text { Nations, Ltd., et al. v. } \\
\text { United States of America, } \\
\text { UNCIRAL, Award, } 12 \\
\text { January 2011 (paras. } 59 \\
\text { and 210-211) }\end{array}$ & NAFTA & $\begin{array}{l}\text { General reference to the } \\
\text { Declaration as a whole and to its } \\
\text { Article 19: "States shall consult } \\
\text { and cooperate in good faith with } \\
\text { the indigenous peoples } \\
\text { concerned through their own } \\
\text { representative institutions in } \\
\text { order to obtain their free, prior } \\
\text { and informed consent before } \\
\text { adopting and implementing } \\
\text { legislative or administrative } \\
\text { measures that may affect them." }\end{array}$ & $\begin{array}{l}\text { "It may well be, as the Claimants urged, that there does exist a principle of customary international law requiring governmental authorities to consult indigenous peoples on } \\
\text { governmental policies or actions significantly affecting them. [...] As pointed out by the Claimants, the duty of states to consult with indigenous peoples is featured in the UN } \\
\text { Declaration of the Rights of Indigenous Peoples, particularly in its Article } 19 \text { as well as in several other articles. In its Counter-Memorial the Respondent maintained in } \\
\text { sweeping terms that the Declaration does not represent customary international law, as did Canada in its non-disputing party submission. However, when questioned by the } \\
\text { Tribunal on this point at the hearing, the Respondents' counsel stated that some parts of the Declaration could reflect fundamental human rights principles and emerging } \\
\text { customary law. } \\
\text { In any event, any obligations requiring consultation run between the state and indigenous peoples as such, that is, as collectivities bound in community. Article } 19 \text { of the U.N. } \\
\text { Declaration provides that 'States shall consult with indigenous peoples throught their own representativin institutions.'. It would go well beyond any articiulation of the indigenous } \\
\text { consultation norm, as well as far beyond its conceptual foundations as understood by the Tribunal, to hold that the norm obliges consultations with individual investors such as } \\
\text { Arthur Montour [...]." }\end{array}$ \\
\hline \multicolumn{4}{|r|}{ UNIVERSAL DECLARATION OF HUMAN RIGHTS (1948) } \\
\hline 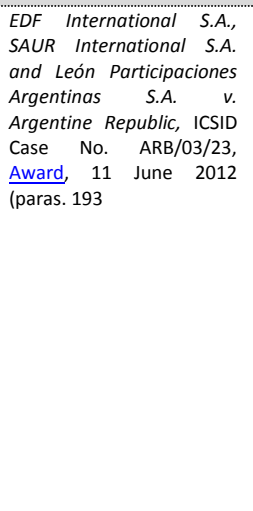 & $\begin{array}{l}\text { Argentina- } \\
\text { France BIT } \\
\text { Argentina- } \\
\text { Belgium- } \\
\text { Luxembourg BIT }\end{array}$ & $\begin{array}{l}\text { General reference to the } \\
\text { Declaration as a whole }\end{array}$ & 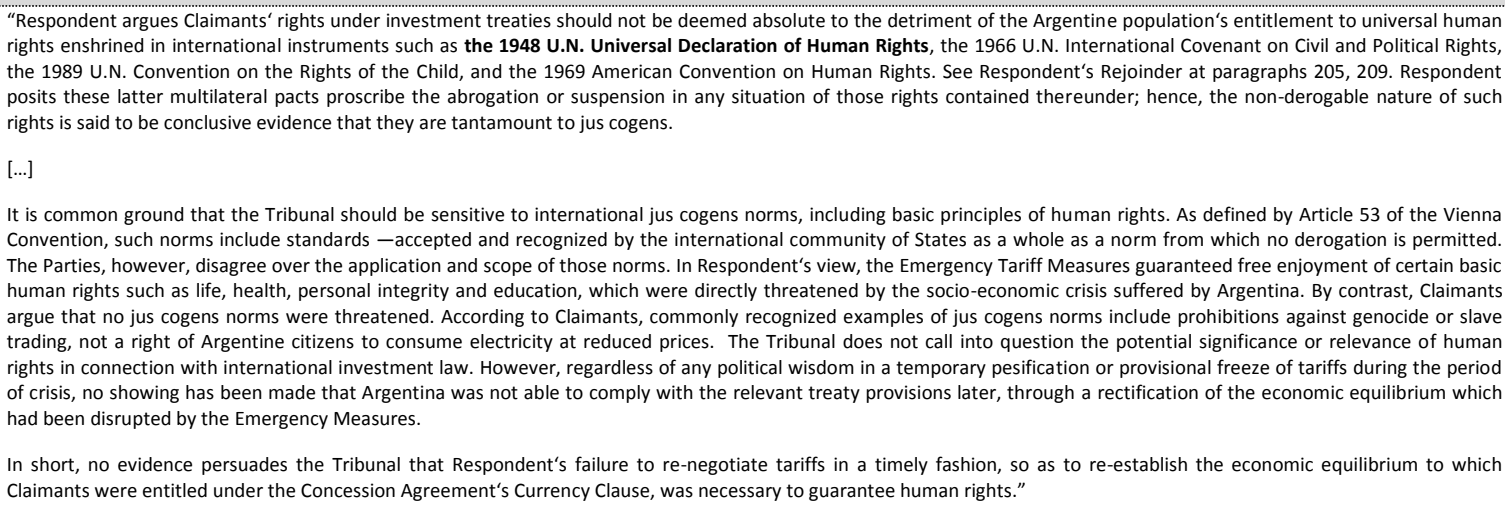 \\
\hline
\end{tabular}




\begin{tabular}{|c|c|c|c|}
\hline $\begin{array}{l}\text { REFERENCE OF } \\
\text { DOCUMENT }\end{array}$ & $\begin{array}{l}\text { JURISDICTIONAL } \\
\text { BASIS }\end{array}$ & $\begin{array}{c}\text { ARTICLES OF THE AGREEMENT } \\
\text { CITED }\end{array}$ & RELEVANT EXTRACT \\
\hline 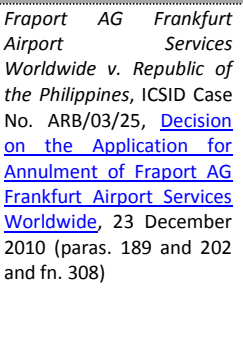 & $\begin{array}{l}\text { Germany- } \\
\text { Philippines BIT }\end{array}$ & $\begin{array}{l}\text { General reference to the } \\
\text { Declaration as a whole }\end{array}$ & $\begin{array}{l}\text { "The principle nullum crimen sine lege encapsulates a fundamental human rights principle in the construction of criminal law for the protection of the accused that ' }[n] \text { one one } \\
\text { shall be held guilty of any penal offence on account of any act or omission which did not constitute a penal offence, under national or international law, at the time when it was } \\
\text { committed.' [...] But it would be a distortion of the important function of the principle to consider it applicable in the present context as a fundamental rule of procedure. } \\
\text { The maxim 'in dubio pro reo' also encapsulates an important human rights protection that '[e]veryone charged with a penal offence has the right to be presumed innocent until } \\
\text { proved guilty according to law in a public trial at which he has adad all the guarantees necessary for his defence.' But such a principle cannot be applied in the context of } \\
\text { international arbitral proceedings instituted by an investor against a state. Indeed, the application of such a presumption could itself, in the context of ICSID proceedings, } \\
\text { amount to a failure of due process since it may unbalance the essential equality between the parties. } \\
\text { [...] } \\
\text { "The right to present one's case is also accepted as an essential element of the requirement to afford a fair hearing accorded in the principal human rights instruments. This } \\
\text { principle requires both equality of arms and the proper participation of the contending parties in the procedure, these being separate but related fundamental elements of a } \\
\text { fair trial."." }\end{array}$ \\
\hline $\begin{array}{l}\text { loan Micula, Viorel Micula } \\
\text { and others v. Romania, } \\
\text { InSID Case No. ARB/05/20, } \\
\text { Decision on Jurisdiction } \\
\text { and Admissibility } 24 \\
\text { September } 2008 \text { (paras. } \\
\text { 87-88) }\end{array}$ & $\begin{array}{l}\text { Romania- } \\
\text { Sweden BIT }\end{array}$ & $\begin{array}{l}\text { Reference to Article } 15 \text { of the } \\
\text { Declaration: "(1) Everyone has } \\
\text { the right to a nationality; (2) No } \\
\text { one shall be arbitrarily deprived } \\
\text { of his nationality nor denied the } \\
\text { right to change his nationality." }\end{array}$ & $\begin{array}{l}\text { "The Parties disagree as to the role of international law in the Tribunal's interpretation of Article } 1 \text { of the BIT with respect to nationality. The Tribunal is of the opinion that in } \\
\text { interpreting the BIT, i.e., an instrument between two sovereign States, it may take into account, as directed by Article } 31(3)(\text { in (c) of the Vienna Convention on the Law of Treaties, } \\
\text { any relevant rules of international law. The Tribunal is also mindful of the role of international law when nationality is acknowledged for international purposes. Indeed, it is well } \\
\text { established that the acquisition of nationality must not be inconsistent with international law [...]. } \\
\text { In making its determination, the Tribunal will be mindful of Article } 15 \text { of the Universal Declaration of Human Rights according to which everyone has the right to a nationality, } \\
\text { and that no one shall be arbitrarily deprived of his nationality nor denied of the right to change his nationality.". }\end{array}$ \\
\hline
\end{tabular}




\section{(iii) Anti-corruption Agreements}

\begin{tabular}{|c|c|c|c|}
\hline REFERENCE OF DOCUMENT & $\begin{array}{l}\text { JURISDICTIONAL } \\
\text { BASIS }\end{array}$ & \multicolumn{2}{|c|}{ ARTICLES OF THE AGREEMENT CITED } \\
\hline \multicolumn{4}{|r|}{ AFRICAN UNION CONVENTION ON PREVENTING AND COMBATING CORRUPTION (2003) } \\
\hline $\begin{array}{l}\text { Metal-Tech Ltd. v. } \\
\text { Republic of Uzbekistan, } \\
\text { ICSID Case No. ARB/10/3, } \\
\text { Award, } 4 \text { October } 2013 \\
\text { (para. 291) }\end{array}$ & $\begin{array}{l}\text { Israel- Uzbekistan } \\
\text { BIT }\end{array}$ & $\begin{array}{l}\text { General reference to the } \\
\text { Convention as a whole }\end{array}$ & $\begin{array}{l}\text { "In addition to early bilateral treaties providing for extradition in cases of corruption, manifestations of the fight against corruption are found at the multiliateral level in the } \\
\text { Vienna Convention of the Law of Treaties and in the ICSID Convention [...] The international community of States has thereafter sought to address the issue of corruption } \\
\text { with a targeted effort to eliminate corrupt practices in the public service sector and criminalize corruption in domestic legal orders [...] } \\
\text { [A] number of international agreements were adopted mainly seeking to criminalize corruption, but also dealing with administrative and civil law aspects relating to the } \\
\text { fight against corrutution. These include the } 1996 \text { Inter-American Convention against Corruption, the } 1997 \text { OECDD Convention on Combating Bribery of Foreign Public officials } \\
\text { in International Business Transactions; the } 1999 \text { Council of Europe Civil Law Convention on Corruption; the } 1999 \text { Criminal Law Convention on Corruption and the } 1999 \text { Civil } \\
\text { Law Convention on Corruption, both adopted under the aegis of the Council of Europe; the } 2003 \text { African Union Convention on Preventing and Combating Corruption; and } \\
\text { the } 2004 \text { UN Convention against Corruption." }\end{array}$ \\
\hline $\begin{array}{l}\text { Metal-Tech Ltd. v. } \\
\text { Republic of Uzbekistan, } \\
\text { ICSID Case No. ARB/10/3, } \\
\text { Award, } 4 \text { October } 2013 \\
\text { (para. 291) }\end{array}$ & $\begin{array}{l}\text { Israel- Uzbekistan } \\
\text { BIT }\end{array}$ & $\begin{array}{l}\text { General reference to the } \\
\text { Conventions }\end{array}$ & 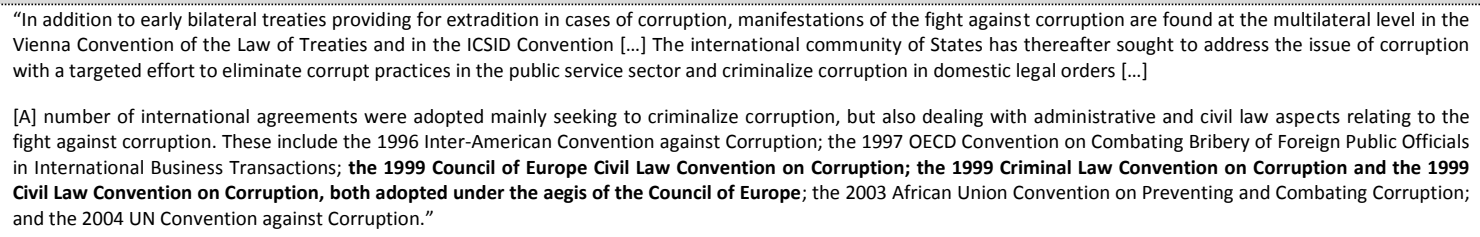 \\
\hline \multicolumn{4}{|c|}{ OECD CONVENTION ON COMBATING BRIBERY OF FOREIGN PUBLIC OFFICIALS IN INTERNATIONAL BUSINESS TRANSACTIONS (1997) } \\
\hline $\begin{array}{l}\text { Metal-Tech Ltd. v. } \\
\text { Republic of Uzbekistan, } \\
\text { ICSID Case No. ARB/10/3, } \\
\text { Award, } 4 \text { October } 2013 \\
\text { (para. 291) }\end{array}$ & $\begin{array}{l}\text { Israel- Uzbekistan } \\
\text { BIT }\end{array}$ & $\begin{array}{l}\text { General reference to the } \\
\text { Convention as a whole }\end{array}$ & $\begin{array}{l}\text { "In addition to early bilateral treaties providing for extraditition in cases of corruption, manifestations of the fight against corruption are found at the multiliateral level in the } \\
\text { Vienna Convention of the Law of Treaties and in the ICSID Convention [...] The international community of States has thereafter sought to address the issue of corruption } \\
\text { with a targeted effort to eliminate corrupt practices in the public service sector and criminalize corruption in domestic legal orders [...] } \\
\text { [A] number of international agreements were adopted mainly seeking to criminalize corruption, but also dealing with administrative and civil law aspects relating to the } \\
\text { fight against corruption. These include the } 1996 \text { Inter-American Convention against Corruption; the } 1997 \text { OECD Convention on Combating Bribery of Forigig Public } \\
\text { Officials in International Business Transactions; the } 1999 \text { Council of Europe Civil Law Convention on Corruption; the } 1999 \text { Criminal Law Convention on Corruption and the } \\
1999 \text { Civil Law Convention on Corruption, both adopted under the aegis of the Council of Europe; the } 2003 \text { African Union Convention on Preventing and Combating } \\
\text { Corruption; and the } 2004 \text { UN Convention against Corruption." }\end{array}$ \\
\hline $\begin{array}{l}\text { Sistem Muhendislik Insaat } \\
\text { Sanayi ve Ticaret A.S. } v . \\
\text { Kyrgyz Republic, ICSID } \\
\text { Case No. ARB(AF)/06/1, } \\
\text { Award, } 9 \text { September } 2009 \\
\text { (para. 42) }\end{array}$ & $\begin{array}{l}\text { Kyrgyz Republic- } \\
\text { Turkey BIT }\end{array}$ & $\begin{array}{l}\text { Reference to Article 1: "Each Party } \\
\text { shall take such measures as may be } \\
\text { necessary to establish that it is a } \\
\text { criminal offence under its law for } \\
\text { any person intentionally to offer, } \\
\text { promise or give any undue } \\
\text { pecuniary or other advantage, } \\
\text { whether directly or through } \\
\text { intermediaries, to a foreign public } \\
\text { official, for that official or for a third } \\
\text { party, in order that the official act } \\
\text { or refrain from acting in relation to } \\
\text { the performance of official duties, } \\
\text { in order to obtain or retain business } \\
\text { or other improper advantage in the } \\
\text { conduct of international business." }\end{array}$ & $\begin{array}{l}\text { "The OECD Convention, to which the Respondent refers, defines bribery as the offer, promising or giving of 'undue pecuniary or other advantage, whether directly or or } \\
\text { through intermediaries, to a foreign public official, for that official or for a third party, in order that the official act or refrain from acting in relation to the performance of } \\
\text { official duties, in order to obtain or retain business or other improper advantage in the conduct of international business.' } \\
\text { The Tribunal regards that as a reasonable and useful definition." }\end{array}$ \\
\hline
\end{tabular}




\begin{tabular}{|c|c|c|c|c|}
\hline \multirow{2}{*}{ 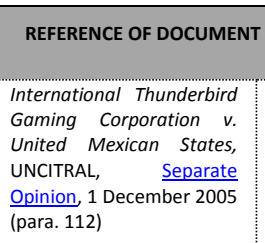 } & $\begin{array}{l}\text { JURISDICTIONAL } \\
\text { BASIS }\end{array}$ & \multicolumn{2}{|c|}{ ARTICLES OF THE AGREEMENT CITED } & RELEVANT EXTRACT \\
\hline & NAFTA & $\begin{array}{l}\text { General reference } \\
\text { Convention as a whole }\end{array}$ & to the & $\begin{array}{l}\text { "It is generally very difficult to prove bribery as there is usually little if any paper trail. However, arbitral tribunals and courts, in particularly of more recent and under the } \\
\text { influence of the authoritative international conventions (mainly, but not exclusively the OECD anti-bribery convention) have been read to use presumptions rather than } \\
\text { full-fledged and hard to obtain full evidence. If a transaction creates enough suspicion so that - in the practice of the US foreign Corrupt Practices Act - a 'red flag' should } \\
\text { show up on the face of the transaction, it is sufficient to require the party in control of such a transaction to prove that it was contrary to 'red flag' indicators a proper one." }\end{array}$ \\
\hline \multicolumn{5}{|r|}{ UNITED NATIONS CONVENTION AGAINST CORRUPTION (2003) } \\
\hline $\begin{array}{l}\text { Metal-Tech Ltd. } \quad \text { v. } \\
\text { Republic of Uzbekistan, } \\
\text { ICSID Case No. ARB/10/3, } \\
\text { Award, } 4 \text { October } 2013 \\
\text { (para. 291) }\end{array}$ & $\begin{array}{l}\text { Israel- Uzbekistan } \\
\text { BIT }\end{array}$ & $\begin{array}{l}\text { General reference } \\
\text { Convention as a whole }\end{array}$ & to the & $\begin{array}{l}\text { "In addition to early bilateral treaties providing for extradition in cases of corruption, manifestations of the fight against corruption are found at the multiliateral level in the } \\
\text { Vienna Convention of the Law of Treaties and in the ICSID Convention [...] The international community of States has thereafter sought to address the issue of corruption } \\
\text { with a targeted effort to eliminate corrupt practices in the public service sector and criminalize corruption in domestic legal orders [...] } \\
\text { [A] number of international agreements were adopted mainly seeking to criminalize corruption, but also dealing with administrative and civil law aspects relating to the } \\
\text { fight against corruption. These include the } 1996 \text { Inter-American Convention against Corruption; the } 1997 \text { OCED Convention on Combating BBibery of Foreign Public Officials } \\
\text { in International Business Transactions; the } 1999 \text { Council of Europe Civil Law Convention on Corruption; the } 1999 \text { Criminal Law Convention on Corruption and the } 1999 \text { Civil } \\
\text { Law Convention on Corruption, both adopted under the aegis of the Council of Europe; the } 2003 \text { African Union Convention on Preventing and Combating Corruption; and } \\
\text { the } 2004 \text { UN Convention against Corruption." }\end{array}$ \\
\hline
\end{tabular}




\section{(iv) Miscellaneous agreements}

\begin{tabular}{|c|c|c|c|}
\hline REFERENCE OF DOCUMENT & $\begin{array}{l}\text { JURISDICTIONAL } \\
\text { BASIS }\end{array}$ & $\begin{array}{l}\text { ARTICLES OF THE AGREEMENT } \\
\text { CITED }\end{array}$ & RELEVANT EXTRACT \\
\hline \multicolumn{4}{|r|}{ JAY TREATY (1794) } \\
\hline $\begin{array}{l}\text { Grand River Enterprises Six } \\
\text { Nations, Ltd., et al. v. } \\
\text { United States of America, } \\
\text { UNCITRAL, Award, } 12 \\
\text { January 2011 (paras. 141- } \\
\text { 143) }\end{array}$ & NAFTA & $\begin{array}{l}\text { General reference to the Treaty } \\
\text { as a whole }\end{array}$ & 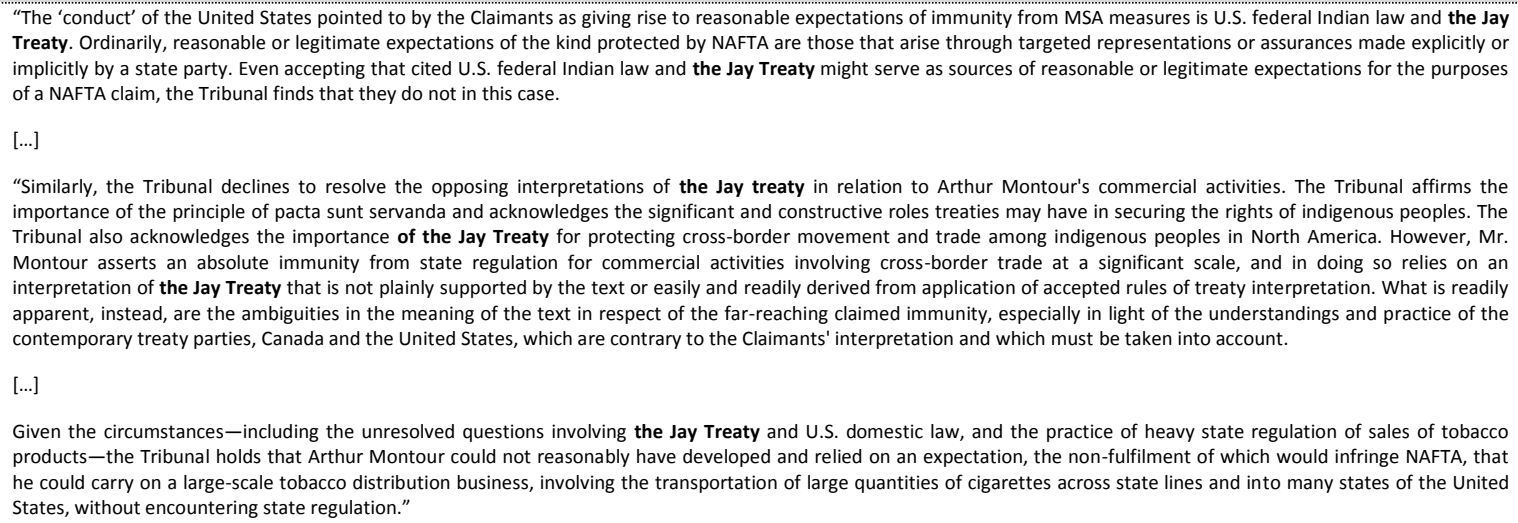 \\
\hline $\begin{array}{l}\text { GAMI Investments, Inc. v. } \\
\text { Government of the United } \\
\text { Mexican States, UNCITRAL, } \\
\text { Final Award, } 15 \text { November } \\
2004 \text { (paras. 39-40) }\end{array}$ & NAFTA & $\begin{array}{l}\text { General reference to the Treaty } \\
\text { as a whole }\end{array}$ & $\begin{array}{l}\text { "As the Umpire put it in the Selwyn case decided in } 1903 \text { by the British-Venezuelan Commission: } \\
\text { 'International arbitration is not affected jurisdictionally by the fact that the same question is in the courts of one of the nations. Such international tribunal has power to } \\
\text { act without reference thereto, and if judgment has been pronounced by such court, to disregard the same so far as it affects the indemnity to the individual, and has } \\
\text { power to make an award in addition thereto or in aid thereof as in the given case justice may require. Within the limits prescribed by the convention constituting it the } \\
\text { parties have created a tribunal superior to the local courts.' } \\
\text { This century-old holding was itself based on venerable authority. The Jay Treaty of } 1794 \text { between the US and Great Britain was concluded to resolve acute controversies in the } \\
\text { wake of the American Revolution. International commissions were established to rule on claims brought by individuals. Some such claims involved citizens of one country } \\
\text { dissatisfied with their treatment by the courts of the other. The British commissioners took the view that the decisions of English courts were final. The US commissioners were } \\
\text { able to secure a majority decision to the contrary. One of them (William Pinckney) put it as follows in The Betsy (1797): } \\
\text { 'neither the United States nor the claimants its citizens are bound to take for just the sentence of the lords, if in fact it is not so; ... the affirmance of an illegal } \\
\text { condemnation, so far from legitimating the wrong done by the original seizure and precluding the neutraf from seeking reparation for it against the British nation, is } \\
\text { peculiarly that very act which consummates the wrong and indisputably perfects the neutral's right of demanding that reparation through the medium of his own } \\
\text { government.' } \\
89 \text { years later Francis Wharton wrote that this is now accepted law.' The Umpire in Selwyn expressly relied on this statement by Wharton." }\end{array}$ \\
\hline
\end{tabular}





\section{ANNEX 4. METHODOLOGY}

\section{Methodology for the International Investment Agreements Survey}

The sample for this survey consists of 2,094 international investment agreements (IIAs), in large majority bilateral investment treaties (BITs), plus a limited number of bilateral free trade agreements (FTAs) and economic partnership agreements (EPAs) including provisions on investment protection. The sample covers the investment agreements that the 54 countries that participate in the Freedom of Investment Roundtables have concluded with any other country. ${ }^{55}$ The sample includes the IIAs that were publicly available by mid-March 2014 . The available treaties have been included regardless of whether they are in force, or - in a limited number of cases - whether the Parties have signed the documents.

The analysis of treaty texts also covers 13 multilateral investment agreements, including, among others, NAFTA and the Energy Charter Treaty.

The analysis sought to identify any kind of reference to SD/RBC concerns, i.e. language that is commonly associated with the protection of the environment, labour and human rights, as well as with the fight against corruption. The survey technique involves (i) searching for this language in IIAs through key word searches carried out manually and via search engines; (ii) identifying the main characteristics of the SD/RBC language contained in the treaties and (iii) analysing statistically the references identified pursuant to the previously established categorization and the treaties' features. Accordingly, unusual language relating to SD/RBC concerns might have been omitted.

Participants in the FOI Roundtables include Argentina, Australia, Austria, Belgium, Brazil, Bulgaria, Canada, Chile, China, Colombia, Costa Rica, Czech Republic, Denmark, Egypt, Estonia, Finland, France, Germany, Greece, Hungary, Iceland, India, Indonesia, Ireland, Israel, Italy, Japan, Jordan, Korea, Latvia, Lithuania, Luxembourg, Malaysia, Mexico, Morocco, Netherlands, New Zealand, Norway, Peru, Poland, Portugal, Romania, Russian Federation, Saudi Arabia, Slovakia, Slovenia, South Africa, Spain, Sweden, Switzerland, Tunisia, Turkey, United Kingdom, and United States.

\section{Methodology for the Investment Arbitration Cases Survey}

The sample for this survey consists of arbitral decisions, awards and separate opinions rendered by arbitrators and annulment committees. It does not include parties' briefs or amicus curiae submissions.

The sample covers proceedings undertaken pursuant to IIAs but do not include documents from contract-based arbitration proceedings.

The sample includes the dispute documents available on the Investor State Law Guide subscription database as well as on the publicly available Investment Treaty Arbitration website. The documents were included if they were available by mid-March 2014.

55 The term "country" is used for linguistic ease. Its use does not imply any judgement by the OECD as to the legal or other status of any territorial entity. Belgium and Luxembourg have concluded treaties considered in this document jointly as Belgium-Luxembourg Economic Union; while they constitute a joint treaty partner, this report counts the Belgium-Luxembourg Economic Union as two countries. 
The survey technique involves (i) identifying language that is commonly associated with the protection of the environment, labour and human rights, and with the fight against corruption as well as the main characteristics of the language contained in the title of the international agreements dealing with the same issues and (ii) searching for this language in the decisions through key word searches carried out manually and via search engines.

The sample selection and the key word search may be subject to a number of errors, omissions or biases:

- Not finding references because they use non-standard language. The key word search which is based on a standard set of key words for each type of issue or international SD/RBC agreement - assumes a certain amount of standardisation in references to issues or agreements. Therefore, some decisions might not be included if they refer to an issue in a non-standard way or if an international agreement is referred to in in a way that differs from its official name.

- Decisions are not publicly available. The fact that ISDS dispute documents are not always publicly available presents challenges for legal research in this field. For the present study (which is based on all publicly available documents), it may introduce sample selection bias. This is because some decisions - for example, those referring to corruption issues - might be less likely to be made publicly available and would therefore not be included in the sample.

The international agreements surveyed are the following:

\section{i) Environmental Agreements}

- Aarhus Protocol on Persistent Organic Pollutants to the UNECE Convention on Long-Range Transboundary Air Pollution of 1979 (1998)

- Basel Convention on the Control of Trans-boundary Movements of Hazardous Wastes and their Disposal (1989)

- Cartagena Protocol on Biosafety to the Convention on Biological Diversity (2000)

- Convention on Biological Diversity (1992)

- Convention on International Trade in Endangered Species of Wild Flora and Fauna (1963)

- Convention on the Prevention of Marine Pollution by Dumping of Wastes and Other Matter (1972)

- Espoo Convention on Environmental Impact Assessment in a Transboundary Context (1991)

- Kyoto Protocol to the United Nations Framework Convention on Climate Change (1997)

- Montreal Protocol on Substances that Deplete the Ozone Layer (1987)

- North American Agreement on Environmental Cooperation (1993)

- OSPAR Convention - Convention for the Protection of the Marine Environment of the NorthEast Atlantic (1992)

- Resolution adopted by the General Assembly: 1803 (XVII). Permanent sovereignty over natural resources (1962)

- Rio Declaration on Environment and Development (1992)

- Rotterdam Convention on the Prior Informed Consent Procedure for Certain Hazardous Chemicals and Pesticides in International Trade (1998)

- Stockholm Convention on Persistent Organic Pollutants (2001)

- Stockholm Declaration on the Human Environment (1972)

- UNESCO Convention concerning the Protection of the World Cultural Property and Natural Heritage (1972)

- United Nations Convention on the Law of the Sea (1982)

- United Nations Convention to Combat Desertification in those Countries Experiencing Serious Drought and/or Desertification, Particularly in Africa (1994)

- United Nations Framework Convention on Climate Change (1992) 
- United States - Mexico Treaty Relating to the Utilization of Water (1944)

- Vienna Convention for the Protection of the Ozone Layer (1985)

\section{(ii) Human Rights Agreements}

- Charter of Fundamental Rights of the European Union (2000)

- Convention on the Prevention and Punishment of the Crime of Genocide (1948)

- European Convention on Human Rights - Convention for the Protection of Human Rights and Fundamental Freedoms (1950)

- Indigenous and Tribal Peoples Convention No. 169 (1989)

- Inter-American Convention on Human Rights (1969)

- International Convention on the Elimination of All Forms of Racial Discrimination (1965)

- International Covenant on Civil and Political Rights (1966)

- International Covenant on Economic, Social and Cultural Rights (1966)

- Resolution adopted by the General Assembly: 61/295 United Nations Declaration on the Rights of Indigenous Peoples (2007)

- Universal Declaration of Human Rights (1948)

(iii) Anti-corruption Agreements

- African Union Convention on Preventing and Combating Corruption (2003)

- Council of Europe Civil and Criminal Law Conventions on Corruption (1999)

- Inter-American Convention against Corruption (1996)

- United Nations Convention Against Corruption (2003)

- OECD Convention on Combating Bribery of Foreign Public Officials in International Business Transactions (1997)

(iv) Labour Agreements

- Convention concerning Discrimination in Respect of Employment and Occupation (1958)

- Convention concerning Forced or Compulsory Labour (1930)

- Convention concerning Freedom of Association and Protection of the Right to Organize (1948)

- Convention concerning Labour Clauses in Public Contracts (1949)

- Convention concerning Minimum Age for Admission to Employment (1973)

- Convention concerning Occupational Safety and Health and the Working Environment (1981)

- Convention concerning Safety and Health in Agriculture (2001)

- Convention concerning Safety and Health in Construction (1988)

- Convention concerning Safety in the Use of Chemicals at Work (1990)

- Convention concerning the Abolition of Forced Labour (1957)

- Convention concerning the Application of the Principles of the Right to organise and to Bargain Collectively (1949)

- Convention concerning the Prohibition and Immediate Action for the Elimination of the Worst Forms of Child Labour (1999)

- Convention concerning the Promotion of Collective Bargaining (1981)

- Convention concerning Tripartite Consultation to Promote the Implementation of International Labour Standards (1976)

(v) Miscellaneous Agreements

- Jay Treaty (1794) 


\section{OECD Working Papers on International Investment}

http://www.oecd.org/daf/inv/investment-policy/working-papers.htm

2013/4 Temporal validity of international investment agreements: a large sample survey of treaty provisions

2013/3 Investment treaties as corporate law: Shareholder claims and issues of consistency

2013/2 Lessons from Investment Policy Reform in Korea

2013/1 China Investment Policy: an Update

\section{2}

2012/3 Investor-state dispute settlement: A scoping paper for the investment policy community

2012/2 Dispute settlement provisions in international investment agreements: A large sample survey

2012/1 Corporate greenhouse gas emission reporting: A stocktaking of government schemes

2011

$2011 / 2$

Defining and measuring green FDI: An exploratory review of existing work and evidence

$2011 / 1$

Environmental concerns in international investment agreements: a survey

2010

$2010 / 3$

OECD's FDI Restrictiveness Index: 2010 Update

2010/2 Foreign state immunity and foreign government controlled investors

2010/1 Intellectual property rights in international investment agreements

2006

$2006 / 4$

$2006 / 3$

$2006 / 2$

$2006 / 1$

2005

$2005 / 3$

$2005 / 2$

$2005 / 1$

2004

Mobilising Investment for Development: Role of ODA - The 1993-2003 Experience in Vietnam

$2004 / 5$

$2004 / 4$

$2004 / 3$

$2004 / 2$

$2004 / 1$

OECD's FDI regulatory restrictiveness index: Revision and extension to more economies Interpretation of the Umbrella Clause in Investment Agreements Investor-State Dispute Settlement in Infrastructure Projects Improving the System of Investor-State Dispute Settlement: An Overview

Corporate Responsibility Practices of Emerging Market Companies - A Fact-Finding Study Multilateral Influences on the OECD Guidelines for Multinational Enterprises Transparency and Third Party Participation in Investor-State Dispute Settlement Procedures

ODA and Investment for Development: What Guidance can be drawn from Investment Climate Scoreboards?

Indirect Expropriation and the Right to Regulate in International Investment Law

Fair and Equitable Treatment Standard in International Investment Law

Most-Favoured-Nation Treatment in International Investment Law

Relationships between International Investment Agreements 
2003/2 Business Approaches to Combating Corrupt Practices

2003/1 Incentives-based Competition for Foreign Direct Investment: The Case of Brazil

2002

2002/2 Managing Working Conditions in the Supply Chain: A Fact-Finding Study of Corporate Practices

2002/1 Multinational Enterprises in Situations of Violent Conflict and Widespread Human Rights Abuses

2001

2001/6 Codes of Corporate Conduct: Expanded review of their contents

2001/5 The OECD Guidelines for Multinational Enterprises and other corporate responsibility instruments

2001/4 Public policy and voluntary initiatives: What roles have governments played?

2001/3 Making codes of corporate conduct work: Management control systems and corporate responsibility

2001/2 Corporate Responsibility: Results of a fact-finding mission on private initiatives

2001/1 Private Initiatives for Corporate Responsibility: An Analysis

2000

2000/5 Recent trends, policies and challenges in South East European countries

2000/4 Main determinants and impacts of FDI on China's economy

2000/3 Lithuania: Foreign Direct Investment Impact and Policy Analysis

2000/2 Investment Patterns in a Longer-Term Perspective

2000/1 Bribery and the business sector: Managing the relationship

1999

1999/3 Rules for the Global Economy: Synergies between Voluntary and Binding Approaches

1999/2 Deciphering Codes of Corporate Conduct: A Review of their Contents

1999/1 Southeast Asia: the Role of FDI Policies in Development

1998

1998/1 Survey of OECD work on international investment 